Prepared in cooperation with the U.S. Environmental Protection Agency, Great Lakes National Program Office

Concentrations and Estimated Loads of Nutrients, Mercury, and Polychlorinated Biphenyls in Selected Tributaries to Lake Michigan, 2005-6

Scientific Investigations Report 2010-5029 
Cover art: Elements of a study. (Drawing by Benjamin J. Siebers, U.S. Geological Survey, June 2010.) 


\section{Concentrations and Estimated Loads of Nutrients, Mercury, and Polychlorinated Biphenyls in Selected Tributaries to Lake Michigan, 2005-6}

By Stephen M. Westenbroek

Prepared in cooperation with the U.S. Environmental Protection Agency, Great Lakes National Program Office

Scientific Investigations Report 2010-5029 


\section{U.S. Department of the Interior \\ KEN SALAZAR, Secretary \\ U.S. Geological Survey \\ Marcia K. McNutt, Director}

U.S. Geological Survey, Reston, Virginia: 2010

For more information on the USGS—-the Federal source for science about the Earth, its natural and living resources,
natural hazards, and the environment, visit http://www.usgs.gov or call 1-888-ASK-USGS
For an overview of USGS information products, including maps, imagery, and publications,
visit http://www.usgs.gov/pubprod
To order this and other USGS information products, visit http://store.usgs.gov

Any use of trade, product, or firm names is for descriptive purposes only and does not imply endorsement by the U.S. Government.

Although this report is in the public domain, permission must be secured from the individual copyright owners to reproduce any copyrighted materials contained within this report.

Suggested citation:

Westenbroek, S.M., 2010, Concentrations and estimated loads of nutrients, mercury, and polychlorinated biphenyls in selected tributaries to Lake Michigan, 2005-6: U.S. Geological Survey Scientific Investigations Report 2010-5029, $73 \mathrm{p}$. 


\section{Acknowledgments}

This project required coordinated and sustained effort from many people. We gratefully acknowledge their contributions. Gary Kohlhepp and Christine Aiello (Michigan Department of Environmental Quality) rearranged their sampling schedules in order to make coordinated sampling of the Michigan tributaries possible. John Kennedy (Green Bay Metropolitan Sewerage District) offered a place to park a mobile laboratory for nearly a year. Judy Beck (U.S. Environmental Protection Agency, Great Lakes National Program Office) found funding opportunities and tirelessly promoted the idea of gathering updated tributary monitoring data.

Thomas Behrendt, Rick Hubbell, Dave Housner, and Nick Hanson (U.S. Geological Survey) put in very long days collecting and processing large-volume water samples in all weather conditions. Marie Peppler (U.S. Geological Survey) assisted greatly in improving the content and appearance of this report. David Hall (formerly of U.S. Geological Survey) located data archives and provided insight into data analysis and load computation methods in use during the Lake Michigan Mass Balance Project. 


\section{Contents}

Acknowledgments .......................................................................................................................ii

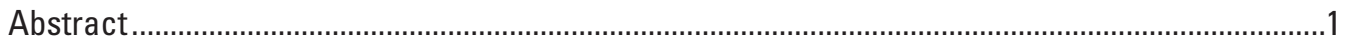

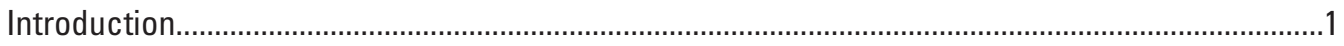

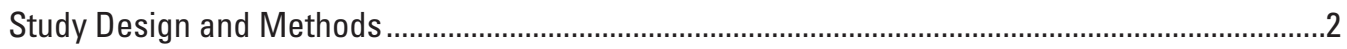

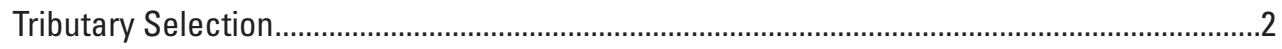

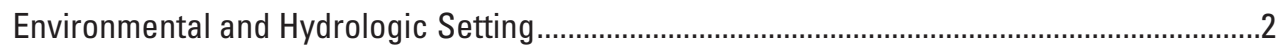

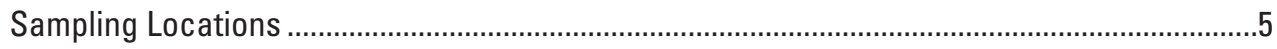

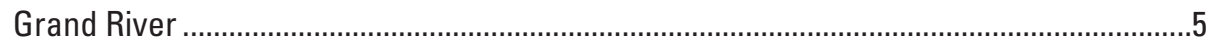

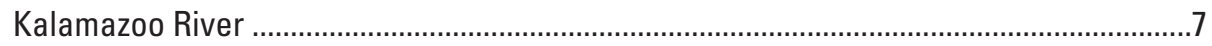

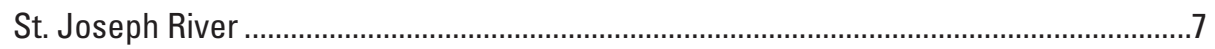

Indiana Harbor and Ship Canal ......................................................................................

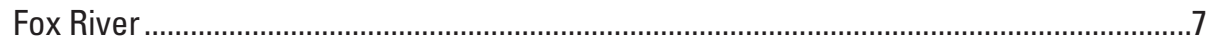

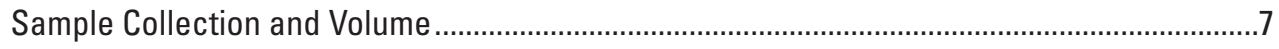

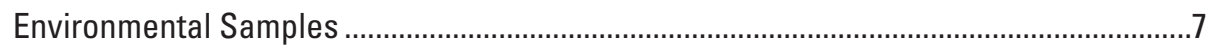

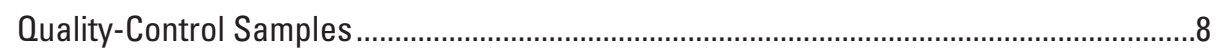

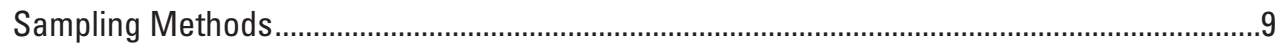

Analytical Methods

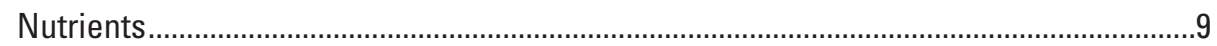

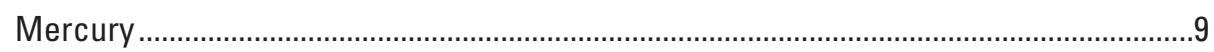

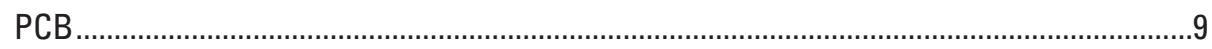

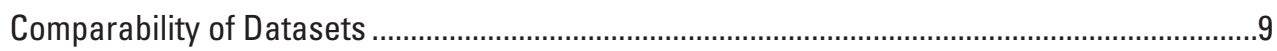

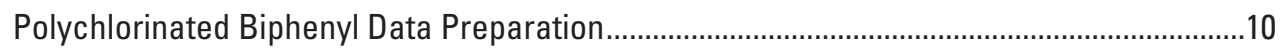

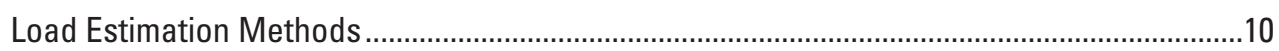

Estimated Loads of Nutrients, Mercury, and Polychlorinated Biphenyls........................................11

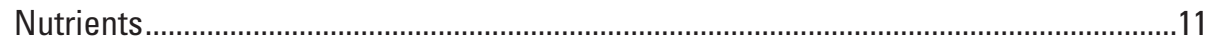

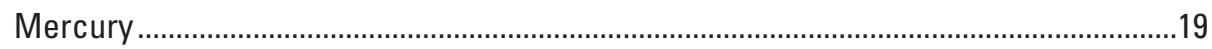

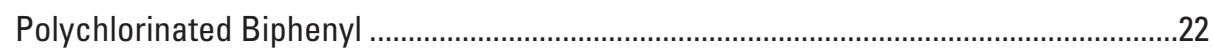

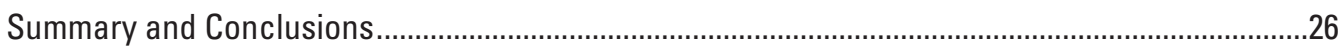

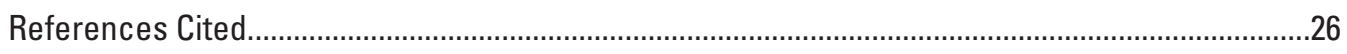

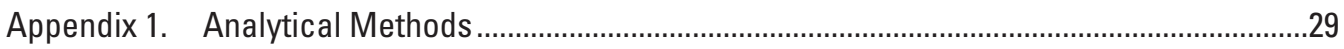

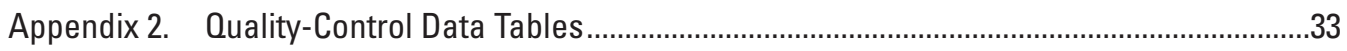

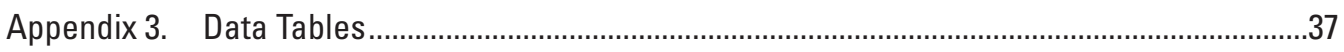

Appendix 4. Concentrations of Ammonia Nitrogen and Total Kjeldahl Nitrogen at Five Lake Michigan Tributary Monitoring Sites...............................................................4

Appendix 5. Calculated Loads ..............................................................................................

Appendix 6. Description of Beale Load Calculation and Jackknifing Procedure ........................59

Appendix 7. Regression Model Details................................................................................61 


\section{Figures}

1. Map showing location of tributary sampling sites for the Lake Michigan Tributary Monitoring Project

2-14. Plots showing:

2. Hydrographs of five Lake Michigan Tributary Monitoring sites, 1994 to 2007 ...........4

3. Comparison of total mercury analyses between the Wisconsin State Laboratory of Hygiene and the U.S. Geological Survey Mercury Research Laboratory 10

4. Example load calculation and jackknifing result for total polychlorinated biphenyl (PCB) at the Fox River, 1994-95

5. Total phosphorus concentrations at five Lake Michigan tributary monitoring sites, 1994-2006

6. Orthophosphate concentrations at five Lake Michigan tributary monitoring sites, 1994-2006

7. Nitrate plus nitrite concentrations at five Lake Michigan tributary monitoring sites, 1994-2006

8. Calculated nutrient loads at five Lake Michigan tributary monitoring sites............18

9. Total mercury concentrations at five Lake Michigan tributary monitoring

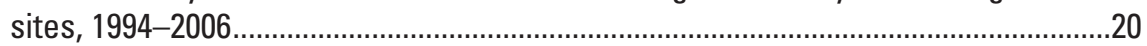

10. Calculated mercury loads at four Lake Michigan tributary monitoring sites..........21

11. Calculated mercury loads at the Fox River tributary monitoring site ......................21

12. Total PCB concentrations at five Lake Michigan tributary monitoring sites, 1994-2006.

13. Calculated PCB loads at five Lake Michigan tributary monitoring sites .................24

14. Calculated total PCB loads for the Lower Fox River, 1989 to 2006 ..........................25

\section{Tables}

1. Calculated median discharge for the five Lake Michigan Tributary Monitoring Sites .....5

2. Sampling locations for the Lake Michigan Tributary Monitoring Project, 2004-05..........6

3. Table of sample volumes and requirements for polychlorinated biphenyls (PCB)...........8

4. Number of samples at each tributary: Lake Michigan Mass Balance Project and this study

5. Definition of practical significance on the basis of effect size.......................................16

6. Adjusted R-squared values, $p$-values, and effect size for total phosphorus

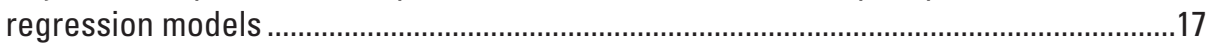

7. Adjusted R-squared values, $p$-values, and effect size for orthophosphate regression models

8. Adjusted R-squared values, $p$-values, and effect size for nitrate plus nitrite regression models.

9. Adjusted R-squared values, p-values, and effect size for total mercury regression models...

10. Adjusted R-squared values, $\mathrm{p}$-values, and effect size for PCB regression models ........22 


\section{Appendix Figures}

4-1. Concentrations of ammonia nitrogen at five Lake Michigan tributary monitoring sites, 1994-2006.

4-2. Concentrations of total Kjeldahl nitrogen at five Lake Michigan tributary monitoring sites, 1994-2006

\section{Appendix Tables}

1-1. Analytical schedule for the Fox River tributary monitoring site .30

1-2. Analytical schedule for the Indiana Harbor and Ship Canal tributary monitoring site

1-3. Analytical schedule for supplemental sampling at the Grand, Kalamazoo, and St. Joseph Rivers .31

2-1. Field replicate results for the Grand River at Eastmanville, Michigan ..............................34

2-2. Field replicate results for the Kalamazoo River at 57th Street.........................................35

2-3. Field replicate results for the St. Joseph River at St. Joseph, Michigan .........................36

3-1. Concentration data for the Grand River near Riverside Park, Ottawa County, Michigan (04119400).

3-2. Concentration data for the Kalamazoo River near New Richmond,

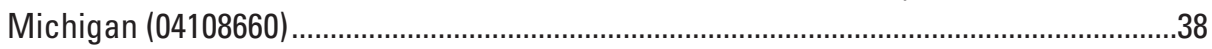

3-3. Concentration data for the St. Joseph River near Zollar Drive, Benton Harbor, Michigan (STORET 110628)

3-4. Concentration data for the Indiana Harbor and Ship Canal at East Chicago, Indiana (04092750)

3-5. Concentration data for the Lower Fox River at Oil Tank Depot at Green Bay, Wisconsin (040851385)

5-1. Estimated annual loads for 1994-2005, site 04120250, Grand River at Grand Haven, Michigan.

5-2. Estimated annual loads for 1994-2005, site 04108670 Kalamazoo River near New Richmond, Michigan

5-3. Estimated annual loads for 1994-2005, site 04102080 St. Joseph River at Napier Avenue at St. Joseph, Michigan.

5-4. Estimated annual loads for 1994-2005, site 04092750 Indiana Harbor Canal at East Chicago, Indiana .

5-5. Estimated annual loads for 1994-2005, site 040851385 Lower Fox River at Oil Tank Depot at Green Bay, Wisconsin ..... 


\section{Conversion Factors, Vertical Datum, and Abbreviations}

\begin{tabular}{lcl}
\hline \multicolumn{1}{c}{ Multiply } & By & \multicolumn{1}{c}{ To obtain } \\
\hline mile $(\mathrm{mi})$ & Length & \\
\hline & 3.281 & kilometer $(\mathrm{km})$ \\
\hline square mile $\left(\mathrm{mi}^{2}\right)$ & Area & \\
\hline & 2.590 & square kilometer $\left(\mathrm{km}^{2}\right)$ \\
\hline liter $(\mathrm{L})$ & Volume & gallon $($ gal $)$ \\
\hline & 0.2642 & \\
\hline cubic foot per second $\left(\mathrm{ft}^{3} / \mathrm{s}\right)$ & Flow rate & cubic meter per second $\left(\mathrm{m}^{3} / \mathrm{s}\right)$ \\
cubic meter per second $\left(\mathrm{m}^{3} / \mathrm{s}\right)$ & 0.02832 & cubic foot per second $\left(\mathrm{ft}^{3} / \mathrm{s}\right)$ \\
\hline & 35.31 & \\
\hline gram $(\mathrm{g})$ & Mass & ounce, avoirdupois $(\mathrm{oz})$ \\
kilogram $(\mathrm{kg})$ & 0.03527 & pound, avoirdupois $(\mathrm{lb})$ \\
megagram $(\mathrm{Mg})$ & 2.205 & ton, short $(2,000 \mathrm{lb})$ \\
\hline
\end{tabular}

Temperature in degrees Celsius $\left({ }^{\circ} \mathrm{C}\right)$ may be converted to degrees Fahrenheit $\left({ }^{\circ} \mathrm{F}\right)$ as follows:

${ }^{\circ} \mathrm{F}=\left(1.8 x^{\circ} \mathrm{C}\right)+32$

Concentrations are given in milligrams per liter $(\mathrm{mg} / \mathrm{L})$, micrograms per liter $(\mu \mathrm{g} / \mathrm{L})$, and nanograms per liter (ng/L). A milligram is one-thousandth of a gram, a microgram is onethousandth of a milligram, and a nanogram is one-thousandth of a microgram.

\section{Abbreviations}

$\begin{array}{ll}\text { AVM } & \text { Acoustic velocity meter } \\ \text { BSRE } & \text { Beale's stratified ratio estimator } \\ \text { LaMP } & \text { Lakewide-area management plan } \\ \text { LMMBP } & \text { Lake Michigan Mass Balance Project } \\ \text { MDEQ } & \text { Michigan Department of Environmental Quality } \\ \text { MI WSC } & \text { Michigan Water Science Center } \\ \text { MRL } & \text { Mercury Research Lab } \\ \text { MWCMP } & \text { Michigan Water Chemistry Monitoring Program } \\ \text { PCB } & \text { Polychlorinated biphenyl } \\ \text { RMSE } & \text { Root mean-squared error } \\ \text { RPD } & \text { Relative percent difference } \\ \text { SLH } & \text { Wisconsin State Laboratory of Hygiene } \\ \text { STORET } & \text { U.S. Environmental Protection Agency data } \\ \text { USGS } & \text { STOrage and RETrieval } \\ \text { WI WSC } & \text { U.S. Geological Survey }\end{array}$


This page is intentionally blank. 


\title{
Concentrations and Estimated Loads of Nutrients, Mercury, and Polychlorinated Biphenyls in Selected Tributaries to Lake Michigan
}

\author{
By Stephen M. Westenbroek
}

\section{Abstract}

The Lake Michigan Mass Balance Project (LMMBP) measured and modeled the concentrations of environmentally persistent contaminants in air, river and lake water, sediment, and fish and bird tissues in and around Lake Michigan for an 18-month period spanning 1994-95. Tributary loads were calculated as part of the LMMBP. The work described in this report was designed to provide updated concentration data and load estimates for 5 nutrients, total mercury, and total polychlorinated biphenyl (PCB) at 5 of the original 11 LMMBP sampling sites.

Samples were collected at five Lake Michigan tributary monitoring sites during 2005 and 2006. Annual loads calculated for the 2005-6 sampling period are as much as 50 percent lower relative to the 1994-95 time period. Differences between the loads calculated for the two time periods are likely related to a combination of (1) biases introduced by a reduced level of sampling effort, (2) differences in hydrological characteristics, and (3) actual environmental change.

Estimated annual total mercury loads during 2005-6 ranged from 51 kilograms per year $(\mathrm{kg} / \mathrm{yr})$ in the Fox River to $2.2 \mathrm{~kg} / \mathrm{yr}$ in the Indiana Harbor and Ship Canal. Estimated annual total PCB loads during 2005-6 ranged from $132 \mathrm{~kg} / \mathrm{yr}$ in the Fox River to $6.2 \mathrm{~kg} / \mathrm{yr}$ in the Grand River.

\section{Introduction}

Long-term monitoring is critical to detecting change in the environment. In 1994 and 1995, baseline conditions for several contaminants of concern were established through water-column sampling at 11 Lake Michigan Mass Balance Project (LMMBP) tributaries. The LMMBP was a multiagency effort to measure the loading, transformation, fate, and transport of contaminants into, out of, and within Lake Michigan.

Designed to provide a framework within which researchers and managers could evaluate the long-term fate of environmentally persistent contaminants, the LMMBP measured and modeled the concentrations of environmentally persistent contaminants in air, river and lake water, sediment, and fish and bird tissues in and around Lake Michigan for an 18-month period spanning 1994 and 1995.

More than 20,000 individual samples were collected between 1993 and 1995 from Lake Michigan tributaries and Lake Michigan water, sediment, air and biota. The LMMBP focused on polychlorinated biphenyl (PCB), trans-nonachlor, atrazine, and total mercury; tributary and air deposition samples also were analyzed for additional parameters such as trace metals, other chlorinated pesticides, and nutrients. A suite of models was developed to simulate the long-term transport and fate of persistent contaminants.

As one component of the LMMBP, more than 350 samples from 11 Lake Michigan tributaries were analyzed for PCB and trans-nonachlor (U.S. Environmental Protection Agency, 2006). Objectives of the LMMBP included estimating relative loading of contaminants from tributaries to Lake Michigan and comparing tributary loads to loads generated from other media, such as through air deposition or sediment resuspension. Flow measurements also were made to support the calculation of load estimates to Lake Michigan from each tributary.

Of the 11 tributaries to Lake Michigan that were sampled during the LMMBP, 8 are currently (2009) listed as "Areas of Concern" under the Unites States-Canada Great Lakes Water Quality Agreement (U.S. Environmental Protection Agency, 2009a). Areas of Concern are identified as those that have conditions likely to cause impairments detrimental to support of aquatic life. All of the Lake Michigan Areas of Concern are on the list in part because of sediments contaminated with mercury, arsenic, or polychlorinated biphenyls.

The project described in this report was designed to revisit 5 of the original 11 LMMBP tributaries, with the goal of generating updated concentration data and loading estimates. Specifically, this project was designed to generate current load estimates for five nutrients, total mercury, and total $\mathrm{PCB}$ at the five selected sampling sites. Concentration data for two of the tributaries, the Fox River and Indiana Harbor and Ship Canal, were generated as a part of this project. Concentration data for the three Michigan tributaries (the Grand, 
Kalamazoo, and St. Joseph Rivers) were not generated as part this project but rather as part of the State of Michigan's Water Chemistry Monitoring Program (Michigan Department of Environmental Quality, 2008). The general approach for this project was developed through discussions between members of the Lake Michigan Monitoring Coordination Council (U.S. Geological Survey, 2008).

The LMMBP goal for model accuracy was to be able to predict lakewide average concentrations in water, sediment, and top predator fish to within a factor of 2; this required determination of tributary mass loadings to within \pm 25 percent of the actual annual average value (U.S. Environmental Protection Agency, 1997a; 1997b). The sampling program described here was smaller in scope than that conducted during the LMMBP and could duplicate neither the sampling frequencies nor the confidence intervals associated with the load estimates that were part of the original project. Nevertheless, knowledge of the changes in calculated loads since completion of LMMBP will be of great value to resource managers, modelers, and other Lake Michigan stakeholders in assessing progress toward meeting environmental goals.

One important use of the LMMBP data and models is in support of the Lakewide Management Plan (LaMP) for Lake Michigan. The LaMP documents an approach to reducing loads of persistent contaminants into and concentrations within Lake Michigan (U.S. Environmental Protection Agency, 2008). Although models can be extremely useful, they cannot substitute for data. The data and load estimates generated by this project will allow for further testing and refinement of the models in support of the LaMP.

This report presents the results of sampling in 2005 and 2006, as well as loading estimates for nutrients, mercury, and PCB. Mass load and uncertainty estimates are presented for the five sampled Lake Michigan tributaries. Concentration and load estimates are compared with the 1994-95 LMMBP concentrations and loading estimates. For the Grand, Kalamazoo, and St. Joseph Rivers, additional data generated by the Michigan Department of Environmental Quality (MDEQ) were used to fill in data gaps for 1999 through 2004 (Michigan Department of Environmental Quality, 2008). The MDEQ data were included in the analysis because they provide insight into the natural year-to-year variability of mass loading estimates.

\section{Study Design and Methods}

This project was designed to generate data of comparable quality to the data generated during the Lake Michigan Mass Balance Project. Accordingly, the study design follows the LMMBP Workplan wherever possible (U.S. Environmental Protection Agency, 1997b; 1997a). This section summarizes the study design and methods used during this project and highlights noteworthy departures from the LMMBP Workplan.

\section{Tributary Selection}

Sampling sites were chosen to focus on the tributaries that had the highest total PCB loads to Lake Michigan during the 1994-95 LMMBP sampling period. Previous monitoring showed that more than 90 percent of the tributary loading of total PCB to Lake Michigan could be captured by sampling five tributaries (U.S. Environmental Protection Agency, 2006). Due to ongoing work by the Michigan Department of Environmental Quality (MDEQ) and the U.S. Geological Survey Michigan Water Science Center (MI WSC), three of the top five PCB-contributing tributaries were already scheduled for intensive sampling during 2005.

Of the 11 tributaries sampled during the LMMBP, the Lower Fox River in Wisconsin (Fox) contributed about 60 percent of the tributary load of total PCB to Lake Michigan. Following this, the Indiana Harbor and Ship Canal and Lower Kalamazoo (Kalamazoo) River each contributed approximately 11 percent of the tributary load of total PCB to Lake Michigan. The next group of tributaries - the Sheboygan, Milwaukee, Lower Grand (Grand), and Lower St. Joseph (St. Joseph) Rivers - each contributed an additional 3 percent. The last group of tributaries - the Menominee, Muskegon, Manistique, and Pere Marquette Rivers - each contributed 1 percent or less to the tributary load of total PCB. Combining sampling at the Fox River in Wisconsin and the Indiana Harbor and Ship Canal in Indiana with the MDEQ sampling at the Grand, Kalamazoo, and St. Joseph Rivers in Michigan was expected to capture more than 90 percent of the current tributary PCB load to Lake Michigan (fig. 1).

In addition, LMMBP results for the sampling locations shown in figure 1 captured tributary loads to Lake Michigan amounting to the following proportions of the total measured tributary load:

$$
\begin{aligned}
& \text { - total phosphorus: } 85 \text { percent } \\
& \text { - orthophosphate: } 87 \text { percent } \\
& \text { - total nitrogen: } 84 \text { percent } \\
& \text { - total mercury: } 88 \text { percent }
\end{aligned}
$$

Thus, focusing monitoring efforts for the current project on the Grand, Kalamazoo, St. Joseph, and Fox Rivers and the Indiana Harbor and Ship Canal was expected to capture a substantial part of the tributary loads for non-PCB constituents as well.

\section{Environmental and Hydrologic Setting}

The three tributaries in Michigan, although different in size, appear to respond in a similar manner to regional weather systems (fig. 2). The Fox River in Wisconsin is a highly regulated river; discharge is controlled by 14 existing or abandoned dams (Wisconsin Department of Natural Resources, 2002). The Indiana Harbor and Ship Canal has a highly stable flow regime; most of the water in the Indiana Harbor and Ship Canal originates as wastewater or cooling water discharge (Risch, 2005). 


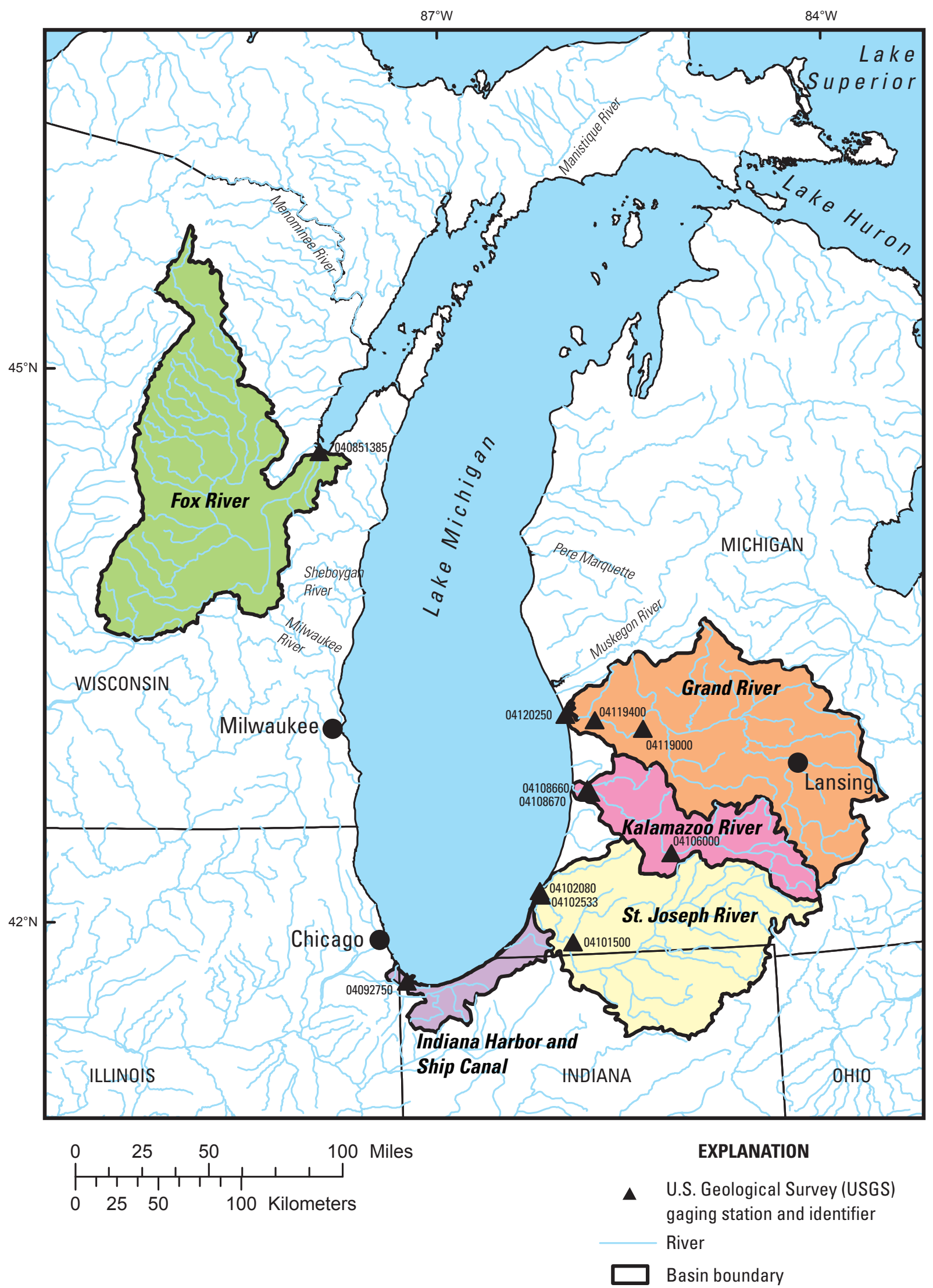

Figure 1. Location of tributary sampling sites for the Lake Michigan Tributary Monitoring Project. USGS gaging stations are described in table 2. 


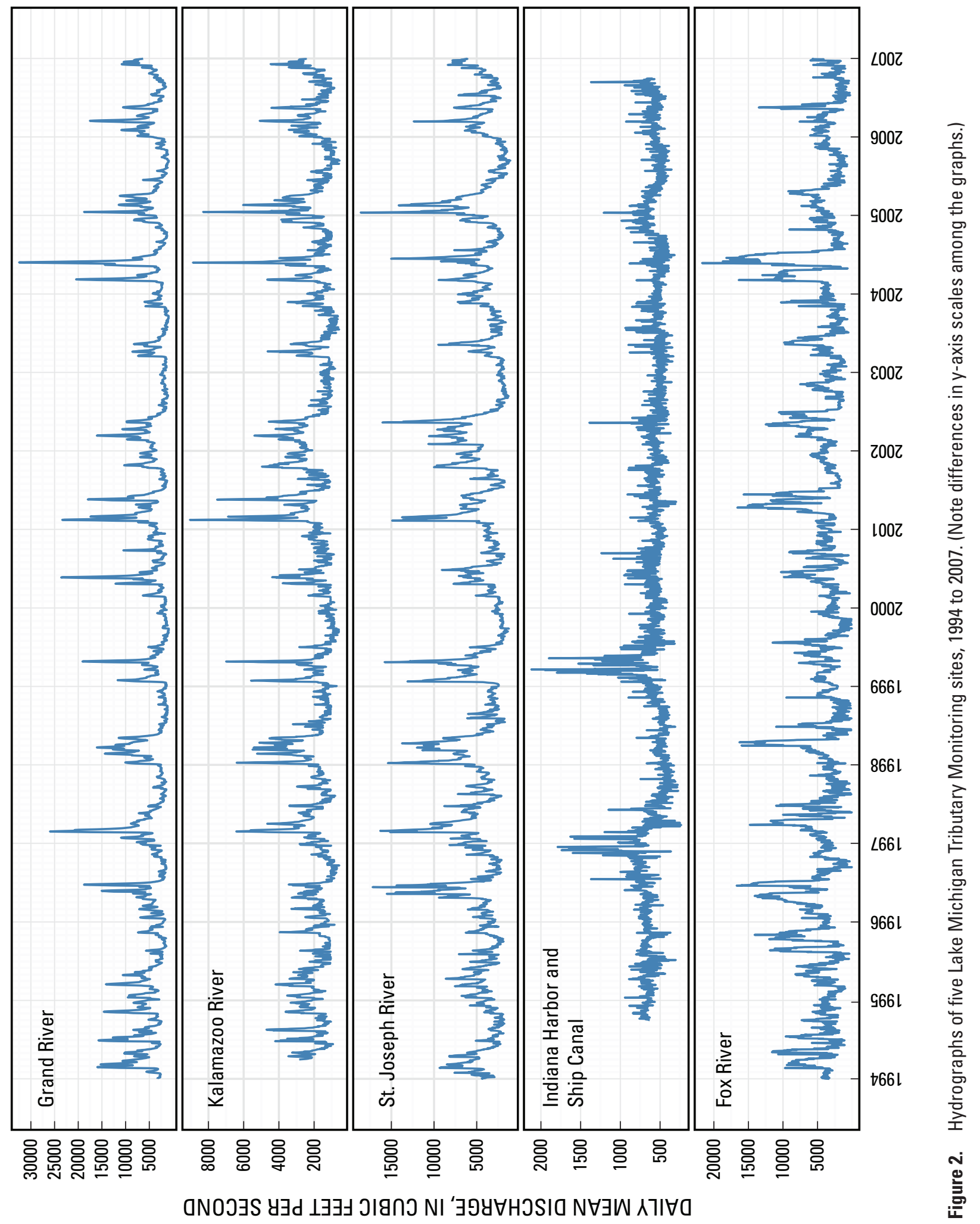


Year-to-year variability in climatic conditions causes corresponding variability in median river discharge (table 1). Median discharges during the LMMBP are given in the first row of table 1. Median discharges during the current round of sample collection (2005-6) are in every case less than the median discharges during the LMMBP.
Three tributaries - the Kalamazoo, Fox, and Indiana Harbor and Ship Canal - have substantial deposits of contaminated sediments within their systems (U.S. Environmental Protection Agency, 2009c). In all three of these tributaries, PCB and mercury have been identified as contaminants of concern (U.S. Environmental Protection Agency, 2009a).

Table 1. Calculated median discharge for the five Lake Michigan Tributary Monitoring Sites. ${ }^{1}$

\begin{tabular}{cccccc}
\hline & \multicolumn{5}{c}{ Discharge, in cubic feet per second } \\
\cline { 2 - 6 } Period & Grand River & $\begin{array}{c}\text { Kalamazoo } \\
\text { River }\end{array}$ & $\begin{array}{c}\text { St. Joseph } \\
\text { River }\end{array}$ & $\begin{array}{c}\text { Indiana Harbor } \\
\text { and Ship Canal }\end{array}$ & Fox River \\
\hline April 1994-September 1995 & 4,966 & 1,999 & 3,681 & 664 & 3,545 \\
1999 & 2,348 & 1,350 & 2,892 & 632 & 3,480 \\
2000 & 3,281 & 1,520 & 3,357 & 565 & 3,355 \\
2001 & 4,562 & 2,483 & 5,057 & 565 & 4,070 \\
2002 & 2,618 & 1,753 & 3,439 & 528 & 3,840 \\
2003 & 1,933 & 1,299 & 3,159 & 524 & 2,910 \\
2004 & 3,253 & 1,753 & 4,134 & 535 & 4,005 \\
2005 & 2,831 & 1,528 & 3,006 & 540 & 3,470 \\
August 2005-July 2006 & 3,337 & 1,616 & 3,325 & 553 & 3,360 \\
\hline
\end{tabular}

${ }^{1}$ Estimated discharge records used for the Grand, Kalamazoo, and St. Joseph Rivers

\section{Sampling Locations}

Locations for the 2005-6 sample collection at the Michigan tributaries differed from those visited in the 1994-95 work. The sampling locations for the Grand River and the St. Joseph Rivers in Michigan were moved upstream from locations near the river mouths. During the LMMBP, AVMs were in operation at both sites; however, they were removed toward the end of 1995. In addition, the stream-gaging and sample-collection station for the Kalamazoo River was discontinued in 1995. For this study, sites were selected at upstream, existing gaging stations that were part of the Michigan Department of Environmental Quality (MDEQ) monitoring network. More detail on sampling-site differences is given below and summarized in table 2 .

\section{Grand River}

During the LMMBP, water samples were collected at the Grand River near USGS gaging station 04120250. The USGS operated an acoustic velocity meter at this site, which was discontinued at the end of the LMMBP. MDEQ has been sampling the Grand River (STORET station 700123) as one of their Michigan Water Chemistry Monitoring Project (MWCMP) "intensive" sites since 1999 (Michigan Department of Environmental Quality, 2008). Water samples for this project were obtained at the MDEQ site (STORET station 700123), which is about 18 river miles upstream from the
LMMBP sampling location (USGS station 04120250). The current sampling location will miss any contributions of contaminants from the Grand Haven area and Spring Lake, although sediment-core samples collected in 1997 and 1998 suggest that there are no "hot spots" of PCB or mercury in the Grand Haven/Spring Lake area (Rediske and others, 1999).

To allow for comparisons to be made among annual loads in 1994-95, 1999, and 2005, a synthetic discharge record was created by use of the continuous daily discharge record from the Grand River at Grand Rapids, Michigan (04119000). A drainage-area ratio approach was used initially in the calculation of a synthetic discharge record (equation 1). Because of differences between synthetic and observed hydrographs, the initial ratio was decreased to improve agreement between the synthetic discharge record and the observed discharge record at the Grand Haven gaging station (04120250).

$$
\text { ratio }_{D A}=\frac{D A_{\text {Grand Haven }}}{D A_{\text {Grand Rapids }}}=\frac{5,518 \text { square miles }}{4,900 \text { square miles }}=1.126
$$

Application of the initial drainage-area ratio resulted in overestimates of discharges in cases in which the daily observed discharge exceeded the median observed discharge. Therefore, the sum of squared error between the observed and synthetic discharge record was minimized, resulting in a corrected drainage-area ratio of 1.122 . 


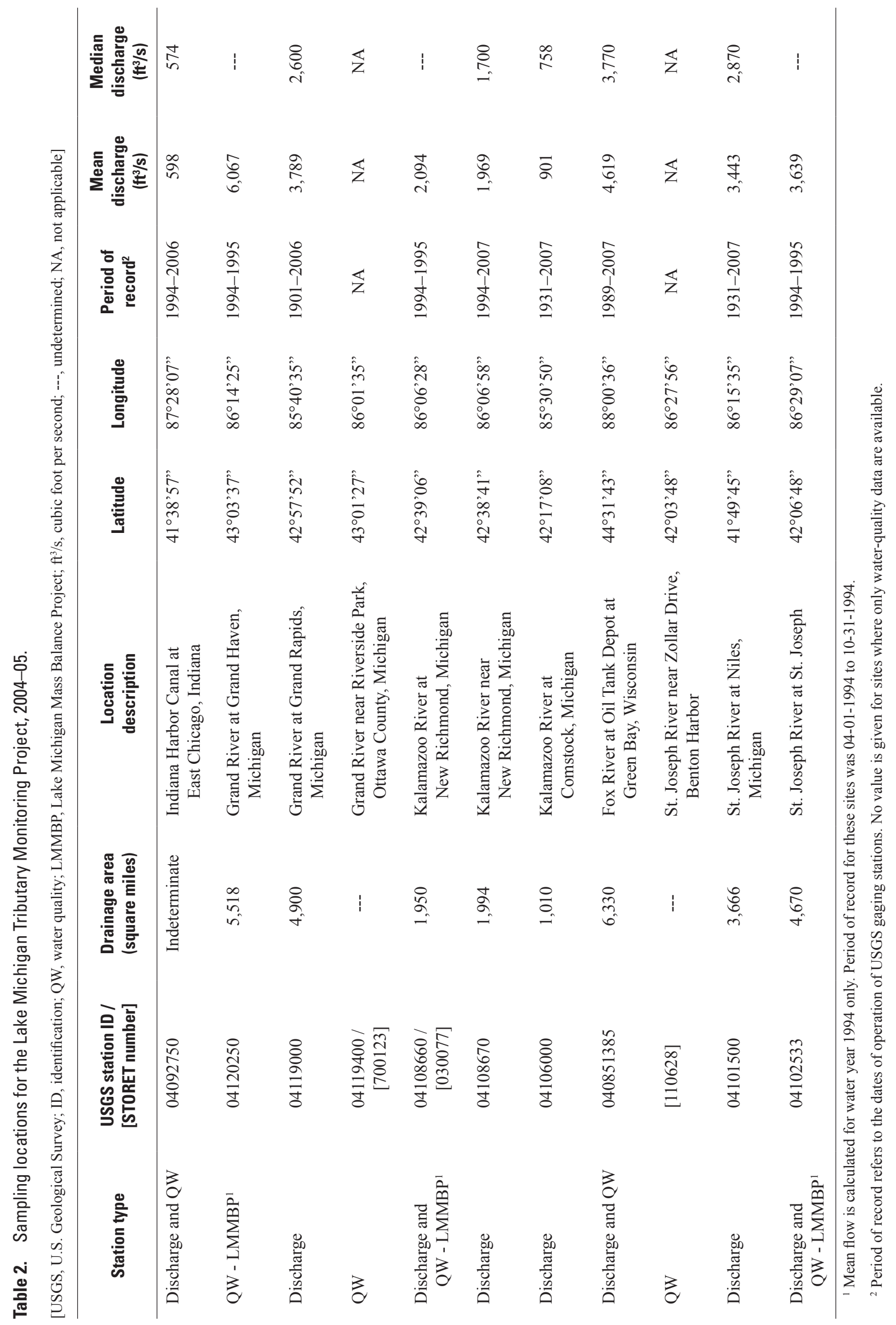




\section{Kalamazoo River}

During the LMMBP, water samples were collected at the Kalamazoo River near USGS gaging station number 04108660. MDEQ has continued to sample the Kalamazoo River at nearly the same location (STORET station 030077) as one of their intensive sites since 1999 (Michigan Department of Environmental Quality, 2008). Gaging station 04108660 was discontinued at the end of the LMMBP. A second USGS gaging station on the Kalamazoo River near New Richmond (04108670) has been in operation intermittently since 1994; operation ceased between 1996 and 2002, leaving a gap in recorded discharge for the Kalamazoo River. In order to allow for comparisons to be made between annual loads in 1994-95, 1999, and 2005, a synthetic discharge record was created by use of the continuous daily discharge record from the Kalamazoo River at Comstock (04106000).

A drainage-area ratio approach was used initially in the calculation of a synthetic discharge record (equation 2). Because of significant differences between synthetic and observed hydrographs, the initial ratio was increased to improve agreement between the synthetic discharge record and the observed discharge record at the New Richmond gaging station (04108670).

$$
\text { ratio }_{D A}=\frac{D A_{\text {NewRichmond }}}{D A_{\text {Comstock }}}=\frac{1,994 \text { squaremiles }}{1,010 \text { squaremiles }}=1.974
$$

Ultimately, a correction factor of 2.14 was applied to daily discharge at the Comstock gaging station to yield a synthetic discharge record for the New Richmond station (04108670); the correction factor was determined by minimizing the sum of squared error between the synthetic and observed daily discharges at the New Richmond station (04108670). The correction factor is about 8 percent larger than the drainage-area ratio between the New Richmond and Comstock sites.

\section{St. Joseph River}

During the LMMBP, samples were collected at the St. Joseph River USGS gaging station 04102533. The USGS operated an AVM at the site, which was removed at the end of the LMMBP. Since 1999, MDEQ has been sampling the St. Joseph River at STORET station 110628 as one of their integrator sites. Integrator sites are sampled intensively on a 5-year rotating schedule (Michigan Department of Environmental Quality, 2008). Sampling done as part of this project was at the same location as the MDEQ work, about $5.8 \mathrm{mi}$ upstream from the sample site used during the LMMBP. The current sampling location will miss any contributions of contaminants from downtown St. Joseph/Benton Harbor and from the Paw Paw River.
To allow for comparisons to be made between annual loads in 1994-95 and 2005, a synthetic discharge record was created by use of the continuous daily discharge record from the St. Joseph River at Niles (04101500). A correction factor of 1.274 was applied to daily discharge at the Niles gaging station to yield a synthetic daily discharge record for site number 04102533; the correction factor is equal to the drainage-area ratio between the two stations (equation 3 ).

$$
\text { ratio }_{D A}=\frac{D A_{\text {St.Joseph }}}{D A_{\text {Niles }}}=\frac{4,670 \text { squaremiles }}{3,666 \text { square miles }}=1.274
$$

\section{Indiana Harbor and Ship Canal}

USGS has operated a gaging station at the Indiana Harbor and Ship Canal East Chicago site (04092750) since October 1991. Water samples for this project were collected at the same location as those collected during the LMMBP.

\section{Fox River}

USGS has operated a gaging station at the Fox River Oil Tank Depot site (040851385) continuously since October 1988. Water samples for this project were collected at the same location as those collected during the LMMBP.

\section{Sample Collection and Volume}

Twelve environmental samples were collected from each tributary. At this level of effort, results of design calculations suggested that a 50-percent change in the mean concentration could be detected at a 95-percent confidence level, and less significant changes in mean concentration were calculated to be correspondingly less likely to be detected as statistically significant.

\section{Environmental Samples}

Twelve water-column samples were obtained from each of the five tributaries included in this study: the Kalamazoo, St. Joseph, and Grand Rivers in Michigan, the Indiana Harbor and Ship Canal in Indiana, and the Fox River in Wisconsin.

The analytical method used to quantify PCB congeners requires large volumes of water to be sampled and run through not only a set of filters but also an ion-exchange resin column (Wisconsin State Laboratory of Hygiene, 1996). The volume of water that must be processed at each site is proportional to the expected water-column PCB concentration; a larger sample volume results in lower analytical detection limits. Sample volumes processed at each tributary are given in table 3 . 
Table 3. Table of sample volumes and requirements for polychlorinated biphenyl (PCB) sampling.

[ng/L, nanograms per liter; LOD, limit of detection]

\begin{tabular}{|c|c|c|c|}
\hline Site & $\begin{array}{l}\text { Required } \\
\text { sample } \\
\text { volume } \\
\text { (liters) }\end{array}$ & $\begin{array}{c}\text { Assumed } \\
\text { minimum } \\
\text { total PCB } \\
\text { concentration } \\
\text { (ng/L) }\end{array}$ & $\begin{array}{c}\text { Sum of } \\
\text { congeners } \\
\text { exceeding } \\
\text { LOD, } \\
\text { assuming a } \\
\text { congener } \\
\text { distribution } \\
\text { of } \\
\text { Aroclor } 1242 \\
\text { (ng/L) }\end{array}$ \\
\hline Grand River & 160 & 0.33 & 0.17 \\
\hline St. Joseph River & 160 & .33 & .17 \\
\hline Kalamazoo River & 160 & 3 & 2.8 \\
\hline $\begin{array}{l}\text { Indiana Harbor } \\
\text { and Ship Canal }\end{array}$ & 80 & 24 & 22.4 \\
\hline \multirow[t]{2}{*}{ Fox River } & 80 & $\begin{array}{c}11 \\
\text { (March-October) }\end{array}$ & 10.3 \\
\hline & 160 & $\begin{array}{c}2.5 \\
\text { (November-February) }\end{array}$ & 2.3 \\
\hline
\end{tabular}

${ }^{1}$ Assumed minimum concentrations of PCB were estimated from observed 1994-95 minimum values of PCB.

The sampling period for the Grand, Kalamazoo, and St. Joseph Rivers extended from March 2005 through December 2005. The sampling period for the Fox River and the Indiana Harbor and Ship Canal extended from roughly August 2005 through July 2006. The ratio of samples collected during high-flow events relative to base-flow conditions was set at 3:1 (event: base flow), which is higher than the 2:1 ratio of high-flow events to base-flow conditions sampled during the LMMBP (U.S. Environmental Protection Agency, 1997a).

Investigators from the USGS Michigan Water Science Center (MI WSC) sampled the 3 Michigan tributaries (Kalamazoo, St. Joseph, and Grand), with the goal of collecting 9 event samples and 3 base flow samples; USGS MI WSC investigators obtained 12 scheduled samples, targeting neither event nor base flow, from the Indiana Harbor and Ship Canal between June 2005 and September 2006. No specific flow conditions were targeted for the Indiana Harbor and Ship Canal because of the extremely stable flow at that site. Table 4 lists the planned level of sampling effort at each tributary for the LMMBP (U.S. Environmental Protection Agency, 1999) and for this study.
Table 4. Number of samples at each tributary: Lake Michigan Mass Balance Project and this study.

\begin{tabular}{|c|c|c|}
\hline \multirow[b]{2}{*}{ Site } & \multicolumn{2}{|c|}{$\begin{array}{l}\text { Number of planned samples (high } \\
\text { flow/base flow) }\end{array}$} \\
\hline & $\begin{array}{c}\text { Lake Michigan } \\
\text { Mass Balance } \\
\text { Project }\end{array}$ & This study \\
\hline $\begin{array}{l}\text { Indiana Harbor and } \\
\text { Ship Canal }\end{array}$ & 16 & 12 \\
\hline Pere Marquette River* & $16(11 / 5)$ & --- \\
\hline Muskegon River* & $16(18 / 8)$ & --- \\
\hline Kalamazoo River & $26(18 / 8)$ & $12(9 / 3)$ \\
\hline St. Joseph River & $26(18 / 8)$ & $12(9 / 3)$ \\
\hline Grand River & $36(24 / 12)$ & $12(9 / 3)$ \\
\hline Manistique River* & $16(18 / 8)$ & --- \\
\hline Menominee River* & $26(18 / 8)$ & --- \\
\hline Fox River & $26(18 / 8)$ & $12(9 / 3)$ \\
\hline Milwaukee River* & $45(30 / 15)$ & --- \\
\hline Sheboygan River* & $45(30 / 15)$ & --- \\
\hline
\end{tabular}

"Not sampled in this study.

The Fox River in Wisconsin was sampled by investigators from the USGS WI WSC with the goal of obtaining nine event samples and three scheduled base-flow samples.

\section{Quality-Control Samples}

Two quality-control samples for water column PCB and mercury analyses were obtained for each tributary during the project. A field duplicate was obtained to assess the combined precision of laboratory and field procedures, and a rinsate blank was processed and submitted to the lab to assess the efficacy of field-equipment cleaning and decontamination procedures. Potential differences in total mercury analysis and reporting between the Wisconsin State Laboratory of Hygiene (SLH) and the USGS Mercury Research Laboratory (MRL) were assessed by sending field duplicates for all Fox River sampling events to both laboratories.

A field duplicate sample was also obtained from each tributary and analyzed for nutrients. In addition, potential differences between the SLH and the MDEQ Environmental Laboratory were assessed by sending three field duplicate samples for each Michigan tributary to both labs for analysis. 


\section{Sampling Methods}

Spatially representative samples were collected at each of the five sites by compositing samples across the river channel. The compositing method was developed for the original LMMBP (U.S. Environmental Protection Agency, 1997b) and is similar to the equal discharge interval method (Porterfield, 1972). The sampling method is designed to yield average constituent concentrations for the river cross section.

At each site, a composite sample was obtained by combining subsamples from three locations across the stream channel. The three sampling points are designed to capture the water moving within subsections of the river having equal discharge rates. Subsamples were collected from 0.2 and 0.8 of the total depth at each of the three sampling points.

\section{Analytical Methods}

A summary of the laboratory analytical methods is provided in appendix 1 . This section discusses differences between analytical methods used in the LMMBP, the Michigan Water Chemistry Monitoring Program (MWCMP), and this project.

\section{Nutrients}

Nutrient concentrations for the Michigan tributaries were determined at the MDEQ Environmental Laboratory. Nutrient concentrations for the Indiana Harbor and Ship Canal and the Fox River were determined at the SLH. Methods used by the two laboratories should be equivalent. Differences between the two methods were quantified with duplicate field samples; the results of the duplicate field samples are included in appendix 2 .

\section{Mercury}

Total mercury analysis for all tributaries was done by the SLH. In addition, field duplicate samples from the Fox River were analyzed for total and dissolved mercury and total and dissolved methylmercury at the USGS MRL.

During the LMMBP, mercury analyses were done at the University of Wisconsin-Madison Water Chemistry Program Laboratory. Since that time, the Water Chemistry Laboratory has discontinued routine analysis for mercury compounds, and the USGS has established a laboratory dedicated to analysis of mercury compounds. The USGS MRL uses methodology developed originally for the LMMBP at the University of Wisconsin-Madison (De Wild and others, 2002). MDEQ has been sending surface-water samples to the SLH for routine total mercury analysis since 1999. Differences between the two methods were quantified with duplicate field samples; the results of the duplicate field samples are included in the next section.
PCB

Analysis of water-column PCB congeners was done at the SLH by method 1293 (Wisconsin State Laboratory of Hygiene, 1996). This method analyzes and reports dissolved and particulate PCB congeners separately, providing information on the partitioning of congeners between particulate and dissolved fractions. For the Michigan tributaries, method 1293 was used, modified in that dissolved and particulate fractions were analyzed and reported together; the modification to method 1293 was because information on partitioning between dissolved and particulate phases was not needed to accomplish the objectives the MWCMP (Michigan Department of Environmental Quality, 2008).

\section{Comparability of Datasets}

Split field samples were obtained to confirm that valid comparisons can be made between results from the LMMBP, the MWCMP, and this project. The use of split field samples was limited to constituents for which either the laboratory or the analytical method differs substantially from those used during the LMMBP. All data collected as part of either the MWCMP or this project appears comparable to data generated during the LMMBP. Specific results of these comparisons are discussed below.

Nutrients. A set of split field samples was obtained to assess differences between the analytical methods used to quantify phosphorus and nitrogen compounds. A summary of these differences is included in appendix 2. The relative percent difference (RPD) between the MDEQ and SLH results appears to increase as the concentrations decrease toward the method reporting limits; at these low concentrations, round-off error and result truncation accounts for some of the increase in relative percent difference. This is not surprising, because analytical variability increases as concentration decreases; the observed increase in RPD would occur even if the split samples were analyzed by the same method.

Mercury. To determine how results from SLH and the USGS MRL compare, split field samples were obtained for all sampling events on the Fox River; the split samples were sent to both labs for total mercury analysis. Figure 3 shows a comparison of quantiles of the field replicate results for total mercury.

A regression of USGS MRL results to SLH results for total mercury yields is expressed by the following equation:

$$
C_{W S C}=0.159+0.902 C_{S L H}
$$




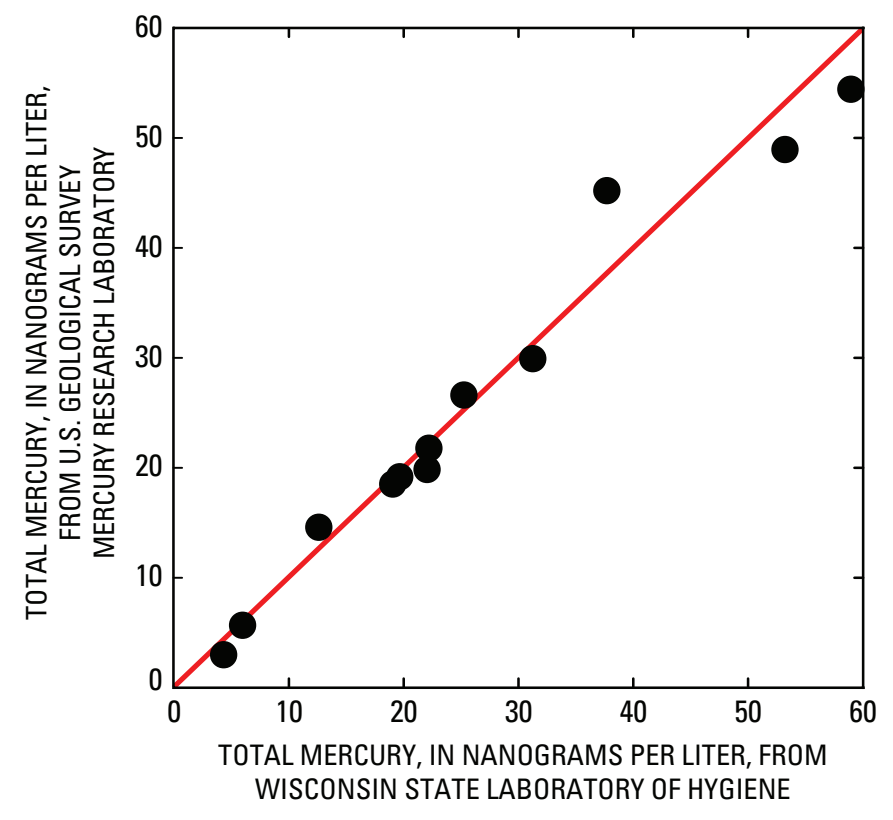

Figure 3. Comparison of total mercury analyses between the Wisconsin State Laboratory of Hygiene and the U.S. Geological Survey Mercury Research Laboratory. Red line is the line of perfect agreement.

In other words, the SLH total mercury results $\left(\mathrm{C}_{\mathrm{SLH}}\right)$ are, on average, approximately 10 percent greater than the USGS $\operatorname{MRL}\left(\mathrm{C}_{\mathrm{MRL}}\right)$ total mercury results. The post-LMMBP loads are calculated with SLH data, and may thus be expected to be as much as 10 percent higher than they would be had the calculations been made with USGS MRL data; the latter laboratory's methods were adapted from those used in the original LMMBP and are therefore assumed to be more comparable to the original methods.

\section{Polychlorinated Biphenyl Data Preparation}

Polychlorinated biphenyls (PCB) are a class of manmade chemicals that were widely used for a variety of industrial applications during the mid-20th century; most uses of PCBs were banned in 1979 (U.S. Environmental Protection Agency, 2009b). A PCB molecule may take one of 209 possible configurations, or congeners (McFarland and Clarke, 1989). Because more than 50 individual congeners may be present in any given sample, it is common to sum the results for the individual congeners and report the sum as total PCB.

Total PCB concentrations included in this report were calculated by summing all congener results that are reported above the level of detection. Thus, the calculated total PCB values include the laboratory-estimated concentrations for results reported at concentrations between the level of detection and the level of quantification.
During the LMMBP, an analytical procedure called surrogate-recovery correction was applied to the PCB congener results; the same surrogate-recovery correction methods were applied to data generated by this project. Complete details regarding the quantification of $\mathrm{PCB}$ are given in volume 2, chapter 1 of the Lake Michigan Mass Balance Methods Compendium (U.S. Environmental Protection Agency, 1997b). A brief description of surrogate spikes and subsequent datacorrection procedures follows.

Surrogate spikes were added to each sample prior to an extraction step (Wisconsin State Laboratory of Hygiene, 1996). For PCB analysis, the surrogate spikes are refined, radiolabeled isolates of congener numbers 14,65 , and 166 , at concentrations of 20,5 , and $5 \mathrm{ng} / \mathrm{mL}$, respectively. Surrogate spike recovery is the ratio of the quantified mass of each surrogate to the mass of surrogate added at the sample extraction step, in percent. It is a way of quantifying the combined performance of the extraction and quantification steps in the analysis.

Surrogate-spike-recovery correction is a process by which the reported analytical results are adjusted by an amount proportional to the surrogate-spike recovery. Congeners are placed into three groups on the basis of their column retention times relative to the column retention times of the three surrogates. The correction is made by dividing the reported analytical result by the appropriate fractional surrogate-spike recovery. PCB concentration data generated for this project have been surrogate-corrected and are summarized in appendix 3 .

\section{Load Estimation Methods}

Beale's stratified ratio estimator (BSRE) was used to generate load estimates. The Beale estimator has been consistently used for estimating Lake Michigan tributary loads since the 1970s (Sonzogni and others, 1978), and it was used during the LMMBP to estimate tributary contaminant loads. Numerical experiments with the BSRE suggest that it generally results in the least biased load estimates for total phosphorus, relative to other regression and ratio estimation techniques (Young and others, 1988); the BSRE has been recommended for application to total phosphorus when concentration data are sparse but a daily discharge record is available (Dolan and others, 1981).

The concept behind any ratio estimator is that one can use more commonly available data, such as discharge, to supplement the more costly data types, such as chemical-concentration data (Cochran, 1977). The key assumption underlying ratio methods is that there is a direct correlation between the two data types. 
The precision of a load estimate may be improved by stratifying, or creating subsets of, data within which the ratio between discharge and concentration is relatively stable. Strata may be formed by assigning samples to groups that share a similar range of collection times, discharge values, or both; the ratio estimator is applied to each stratum, and results are combined to yield a load estimate for the entire calculation period (Cochran, 1977). Stratification of the dataset is done such that the mean square of error is minimized over all strata (Richards, 1999). Load-estimate bias increases and precision decreases as the number of samples in the monitoring program decreases (Richards and Holloway, 1987). These factors were a concern for this study because of the less intensive samplecollection effort compared to that of the LMMBP (table 4).

For this project, loads were calculated by means of the Beale Ratio Estimator on time-stratified datasets. The timestratification scheme and load estimate for each dataset was developed by means of a modified version of AutoBeale (Richards, 1999); the modified version of AutoBeale is described further in appendix 6 . The automated stratification approach taken by AutoBeale generally results in stratification schemes that bracket seasonal changes in concentration and discharge.

To better characterize precision in load estimates, a jackknife approach (Efron and Tibshirani, 1993) was used to estimate tributary loads. The jackknife approach involves calculating loads on successive subsets of the data. During each iteration, one concentration observation is deleted, the load is calculated, and the result is saved. The deleted observation is then restored, and its neighboring observation is deleted, and a new mass loading estimate is made. The result is a set of load estimates, with the number of estimates equal to the number of concentration data points. Figure 4 shows example output from the AutoBeale calculation method with and without application of the jackknife approach. Additional detail is provided in appendix 6 .

\section{Estimated Loads of Nutrients, Mercury, and Polychlorinated Biphenyls}

Concentration data generated from 2005-6 were compared with concentration data from the LMMBP. All data were processed by means of the methods discussed previously to calculate loads (appendix 6). Load estimates for all sites and constituents are given in appendix 5, which includes unstratified, stratified, flow-normalized, and jackknifed load estimates.

In general, the calculated loads for 2005-6 are less than those calculated for the 1994-95, regardless of stratification or effects of flow normalization. The reasons for lower calculated loads in 2005-6 are likely the result of differences in hydrographs between the two time periods, smaller sample sizes relative to the LMMBP effort, and real environmental changes. Patterns and trends in calculated loads for nutrients, mercury, and $\mathrm{PCB}$ are discussed in the following sections.

\section{Nutrients}

Concentrations of total phosphorus, orthophosphate, and nitrate plus nitrite appear to be increasing at some sites. Trends in total phosphorus and orthophosphate concentrations appear to be upward for the Fox River and Indiana Harbor and Ship Canal (figs. 5 and 6). Trends in nitrate plus nitrite concentrations appear to be upward for the Indiana Harbor and Ship Canal, Grand River, and possibly the Kalamazoo River (fig. 7).

In order to test the significance of apparent trends, multiple linear regression models were constructed for the concentration data at each tributary. The regressions generally included suspended solids, air temperature, discharge, and some measure of time as explanatory variables; equation 5 is an example of the regression model form and variables:

$$
\begin{aligned}
\ln (P C B)= & C_{\text {TSS }} \ln (T S S) \\
& +C_{\text {discharge }} \ln (q) \\
& +C_{\text {temperature }} T \\
& +C_{\text {time }} \text { DecYear }
\end{aligned}
$$

where

$\begin{aligned} C & \text { is a regression coefficient, } \\ \text { TSS } & \text { is total suspended solids, } \\ q & \text { is discharge, } \\ T & \text { is air temperature, and } \\ \text { Year } & \text { is the time in decimal years. }\end{aligned}$

For the Fox River and Indiana Harbor and Ship Canal, the time coefficient is an indicator (or dummy) variable to account for the two different observation periods. For the Michigan tributaries, the time coefficient represents the time in decimal years because data from more than two observation periods are present. Air temperature can act as a surrogate for season; nutrients and PCB often exhibit strong seasonality, and therefore, some correlation to air temperature. Some constituents, most notably PCB, strongly sorb to suspended solids.

Concentration data and discharge terms were generally log-transformed prior to regression analysis to ensure that the residuals (observed minus modeled) were normally distributed. The effect size associated with the time coefficient was calculated as shown in equation 6 (Cohen, 1962) by setting all independent variables in the regressions to mean values and altering only the variable associated with the time coefficient.

$$
\text { effect size }=\frac{\mid \text { predicted } \text { value }_{2006}-\text { predicted }_{\text {value }}{ }_{1994} \mid}{\text { std. } \text { deviation }_{\text {all data }}}
$$




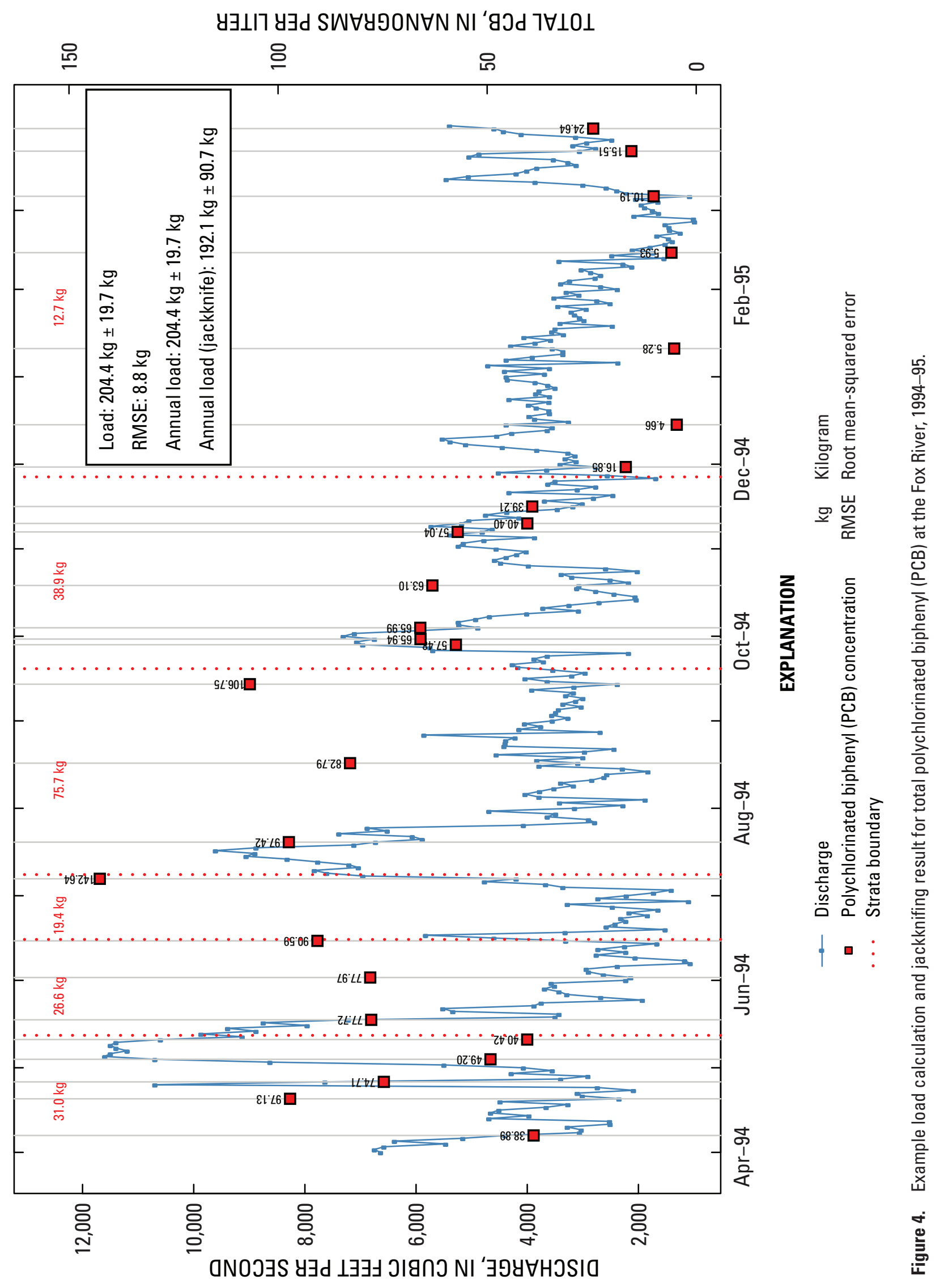



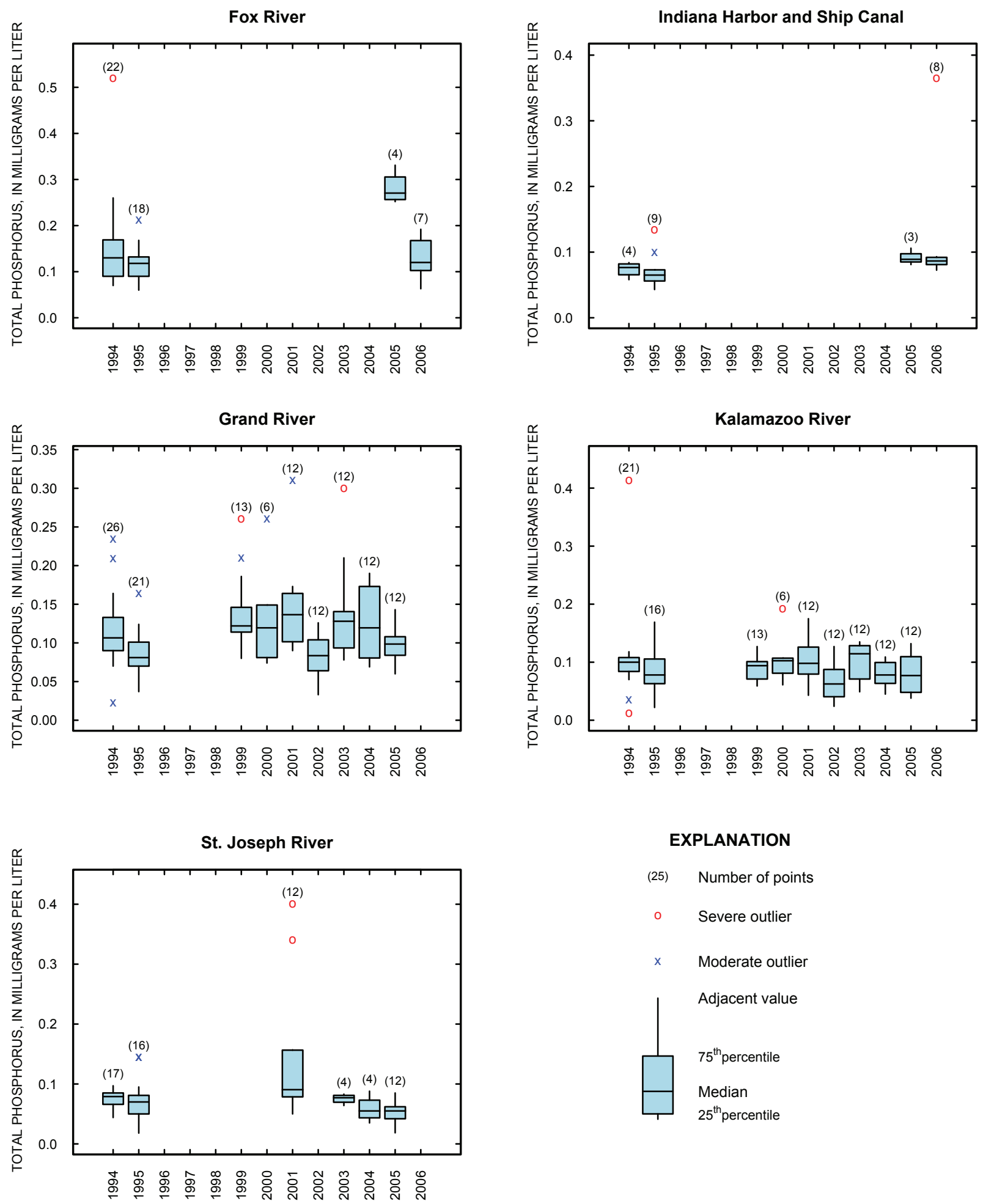

\section{EXPLANATION}

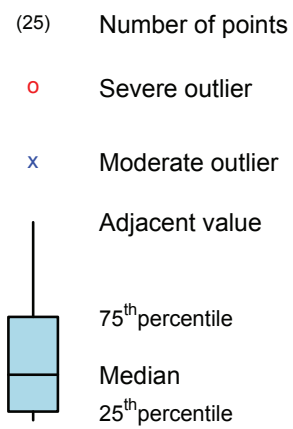

Figure 5. Total phosphorus concentrations at five Lake Michigan tributary monitoring sites, 1994-2006. (Note differences in $\mathrm{y}$-axis scales among the plots.) 

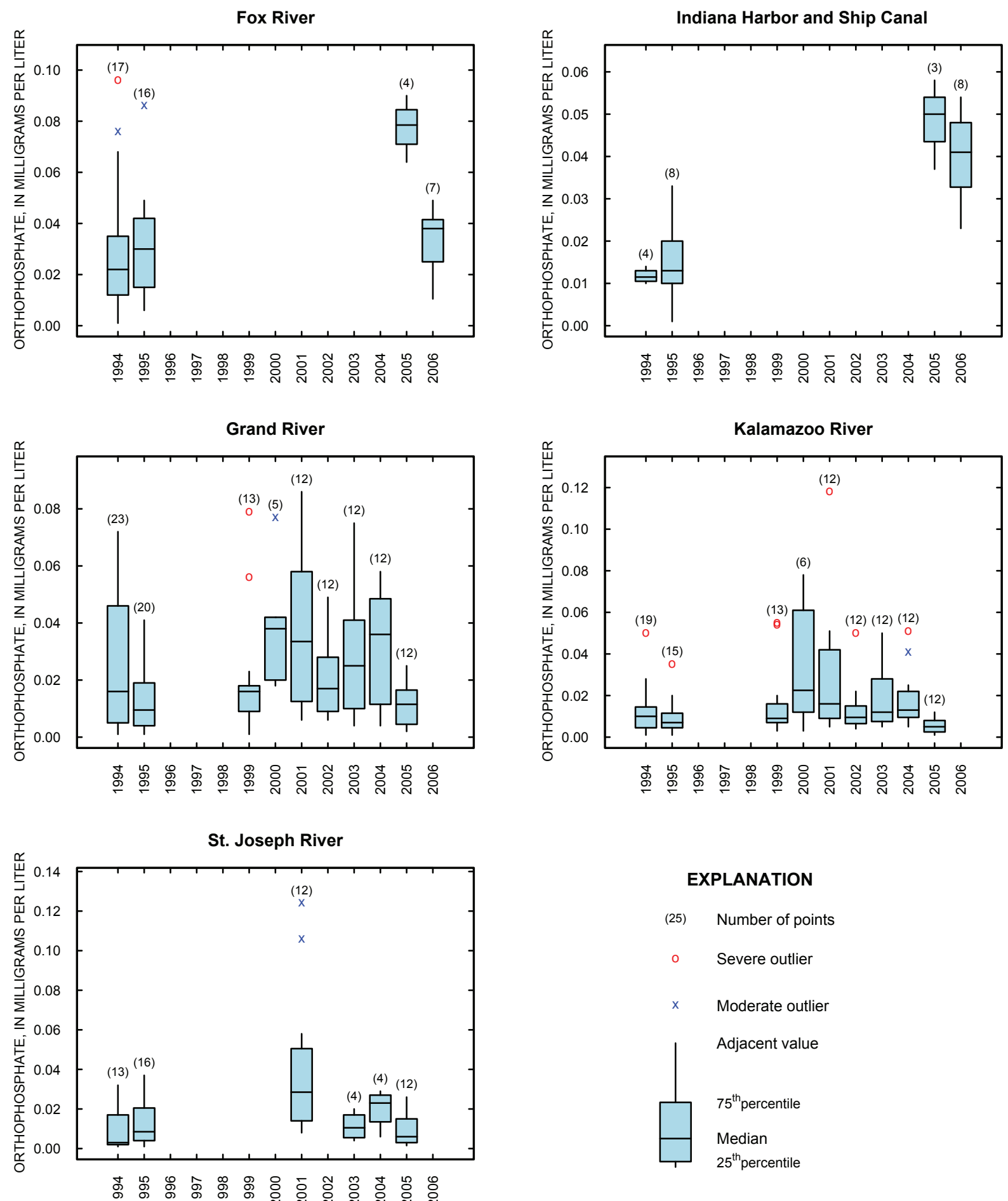

Figure 6. Orthophosphate concentrations at five Lake Michigan tributary monitoring sites, 1994-2006. (Note differences in y-axis scales among the plots.) 

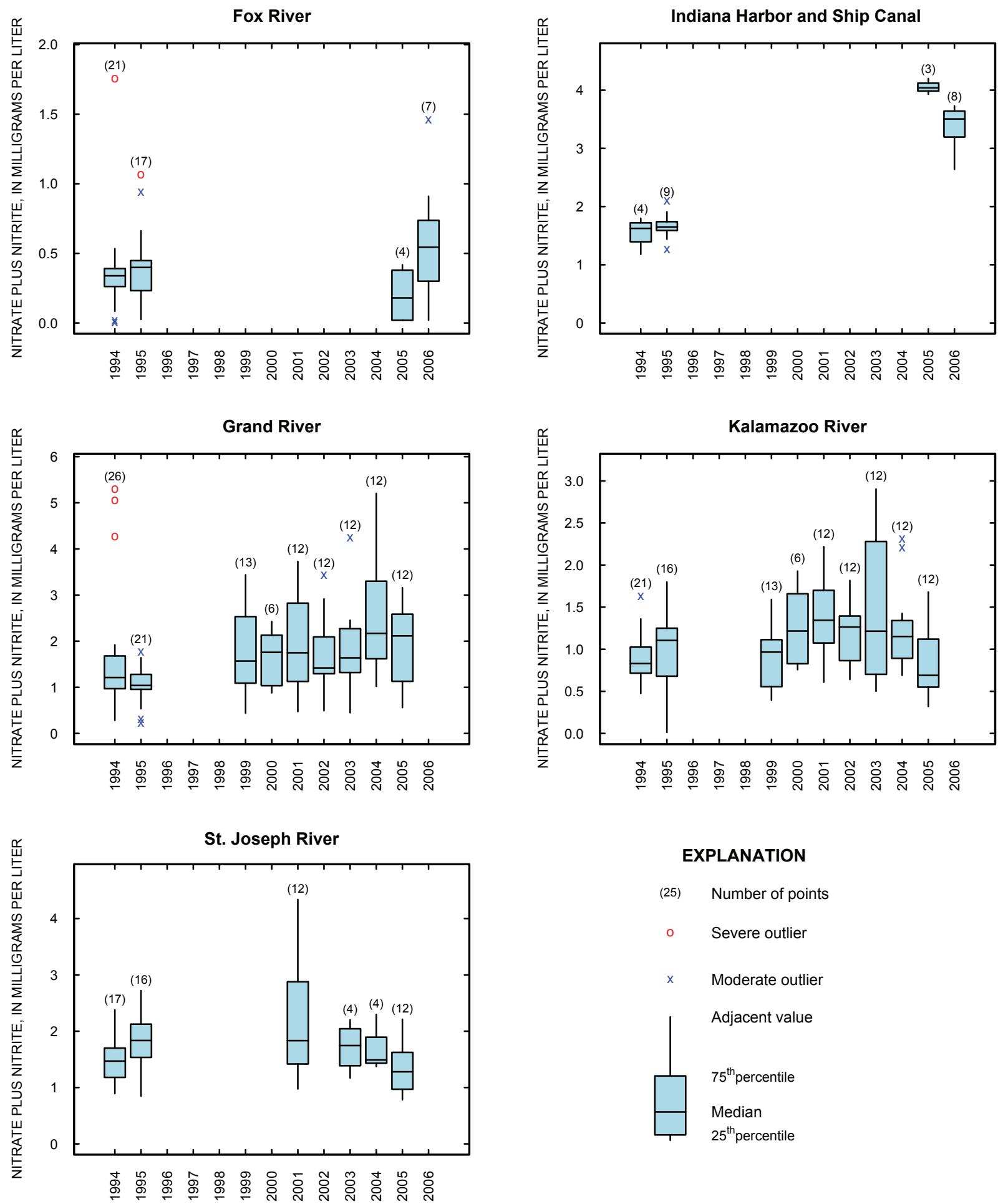

Figure 7. Nitrate plus nitrite concentrations at five Lake Michigan tributary monitoring sites, 1994-2006. (Note differences in $y$-axis scales among the plots.) 
The calculated effect size was used to classify and interpret the practical significance of the multiple linear regression results. For the remainder of this report, effect sizes are described as listed in table 5 . The classifications in table 5 are modeled on those defined by Cohen (1962), and represent a subjective but consistent method to interpret regression results. Thus, a regression time coefficient might be highly statistically significant, but if the effect size as defined in table 5 is negligible, the practical significance of the result would be deemed negligible as well.

Table 5. Definition of practical significance on the basis of effect size.

$[>$, greater than $]$

\begin{tabular}{cl}
\hline Effect size & Practical significance \\
\hline $0-0.5$ & Negligible \\
$0.5-1.0$ & Small \\
$1.0-2.0$ & Moderate \\
$>2.0$ & Large \\
\hline
\end{tabular}

The effect of strong linear relations between predictors (collinearity) was quantified by examining the varianceinflation factors for regressions that contained predictors known to be correlated. When there are strong relations between predictors, the precision of the resulting regression coefficients decreases (Fox, 2008). A variance-inflation factor of 10 is commonly associated with severe collinearity; when the variance-inflation factor exceeds 10 , researchers often eliminate or combine variables to reduce collinearity (O'Brien, 2007). None of the variance-inflation factors examined in this study were greater than 3 , and thus no actions were taken to reduce collinearity. As an additional exploration of the data, a load/air-temperature/discharge plot was examined for each site and each constituent. Examination of the load/air-temperature/ discharge plots provided a visual check and confirmation of the regression results. In addition, these plots confirmed that the more recent sampling events have covered ranges of air temperature and discharge similar to those observed during the LMMBP.

Small to moderate increases in total phosphorus concentrations were identified for the Grand River and Indiana Harbor and Ship Canal (table 6). Statistically significant concentration increases were identified for the St. Joseph and Fox Rivers, but the small effect sizes negate the practical significance of these changes. No statistically significant changes in concentrations were found for the Kalamazoo River.

Small to large increases in orthophosphate concentrations were identified for the Grand River, Indiana Harbor and Ship Canal, and the Fox River (table 7). However, the proportion of variance (R-squared) explained by the regression model for the Fox River is quite low. It has been demonstrated that the choice of variables included in a multiple linear regression can influence the value and significance of the other variables included in the analysis (Mosteller and Tukey, 1977); the addition of other (unknown or unmeasured) variables in this case might render the time-related term insignificant. Although the increases in concentrations of orthophosphate for the Fox River are statistically significant, this result should be viewed cautiously because the underlying model explains so little of the observed variance.

Small to large increases in nitrate plus nitrite concentrations were identified for the Grand and Kalamazoo Rivers and the Indiana Harbor and Ship Canal (table 8). No statistically significant changes in concentrations were found for the Fox and St. Joseph Rivers. For the Indiana Harbor and Ship Canal, the coefficient with the greatest practical and statistical significance is the time-related indicator variable. Inspection of figure 7 shows a near-doubling of the median nitrate plus nitrite value, suggesting that something has changed in the Indiana Harbor and Ship Canal.

The calculated annual nutrient loads show correlation to one another both in time and space, reflecting the influence of regional climate patterns (fig. 8). The black dots represent the load calculated by including all available data, with uncertainty bounds proportional to the mean-squared error over all strata. These uncertainty bounds describe the variability of the ratio between load and flow over each stratum. By contrast, the gray dots on the plot represent the load estimated from data subsets by means of a jackknife approach. The intent was to illustrate how the structure of the sampling program - and indeed, an individual data point - might influence the overall load estimate. Lastly, the red dot represents the jackknife estimate of load: the mean of all jackknife load estimates.

Although a confidence interval can be derived from the jackknifing calculation (appendix 6), jackknife confidence intervals are not reported here; for small sample sizes $(n<20)$, it has been suggested that the jackknife confidence interval may be inaccurate (Hinkley, 1977). A statistical resampling method, such as bootstrapping, could be used to generate uncertainty bounds about the estimated loads. The individual AutoBeale load estimates generated during each jackknife iteration are presented in figure 8 to serve as visual cues regarding the uncertainty of the load estimate.

In most cases, the jackknife estimates are well within the AutoBeale uncertainty bounds, and the mean of all jackknife load estimates falls in line with the AutoBeale-generated load estimate. Exceptions can be seen in the analyses for the Fox River (total phosphorus) and Grand River (ammonia-nitrogen, nitrate plus nitrite, orthophosphate). The AutoBeale-generated load estimate and the jackknife load estimate differ; the elimination of one or more samples from the analysis results in a substantial change in the estimated load. The combined variability in concentration and discharge observed in these cases suggests that sampling would need to be more intensive in future efforts to reduce variability in the estimated load. 
Table 6. Adjusted R-squared values, p-values, and effect size for total phosphorus regression models.

[TSS, total suspended solids; ***, either not statistically significant or of no practical significance; ---, variable removed from regression]

\begin{tabular}{|c|c|c|c|c|c|c|c|}
\hline \multirow[b]{2}{*}{ Tributary name } & \multirow{2}{*}{$\begin{array}{l}\text { Adjusted } \\
\text { R-squared } \\
\text { value }\end{array}$} & \multicolumn{4}{|c|}{ Significance of coefficients ( $p$-value) } & \multirow{2}{*}{$\begin{array}{l}\text { Effect } \\
\text { size }\end{array}$} & \multirow[b]{2}{*}{ Interpretation } \\
\hline & & TSS & $\begin{array}{c}\text { Air } \\
\text { temperature }\end{array}$ & Discharge & Time & & \\
\hline Kalamazoo River & .376 & $2.80 \mathrm{E}-03$ & $1.09 \mathrm{E}-02$ & $1.29 \mathrm{E}-02$ & 8.93E-01 & .02 & $* * *$ \\
\hline St. Joseph River & .574 & $3.10 \mathrm{E}-16$ & --- & --- & $2.16 \mathrm{E}-02$ & .31 & $* * *$ \\
\hline Fox River & .666 & 1.19E-08 & $7.66 \mathrm{E}-02$ & $6.51 \mathrm{E}-02$ & $8.71 \mathrm{E}-02$ & .23 & $* * *$ \\
\hline
\end{tabular}

Table 7. Adjusted R-squared values, p-values, and effect size for orthophosphate regression models.

[TSS, total suspended solids; ---, variable removed from regression; ***, either not statistically significant or of no practical significance]

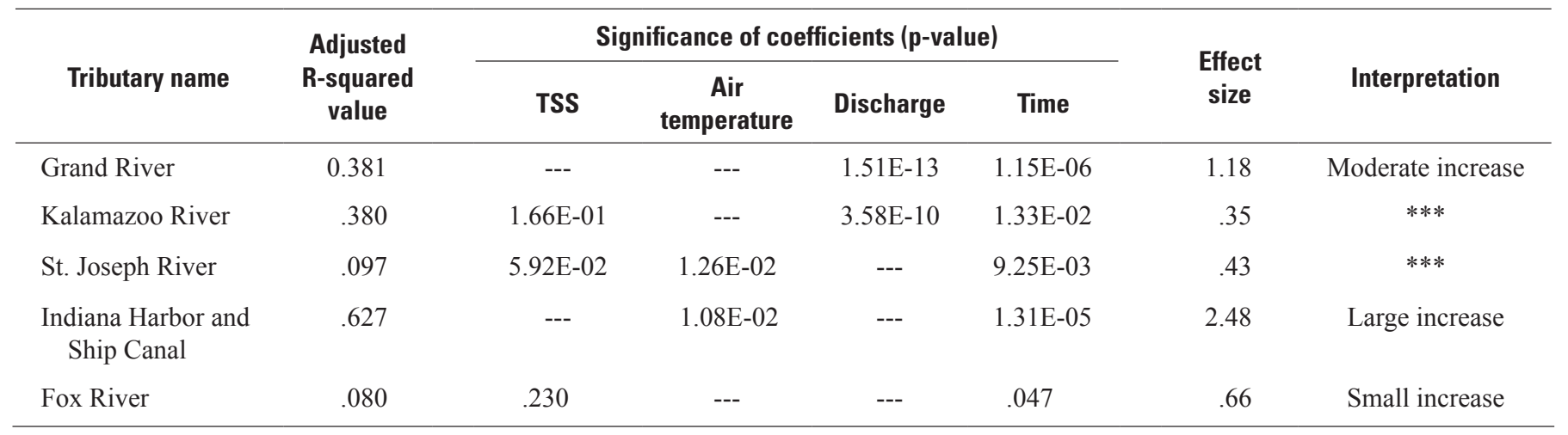

Table 8. Adjusted R-squared values, p-values, and effect size for nitrate plus nitrite regression models.

[TSS, total suspended solids; ---, variable removed from regression; <, less than; ***, either not statistically significant or of no practical significance]

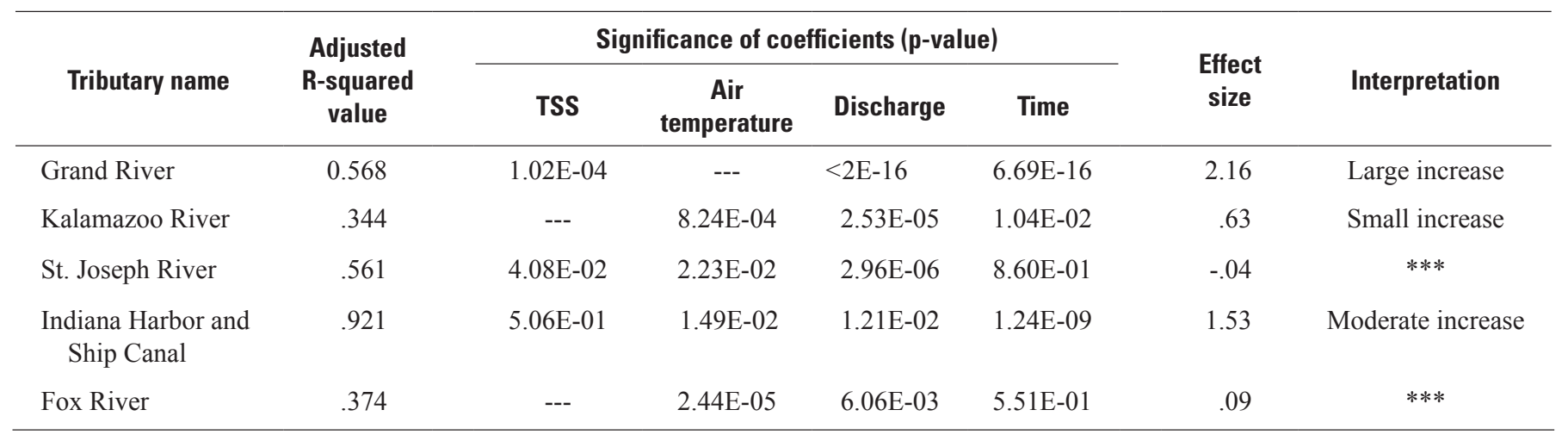




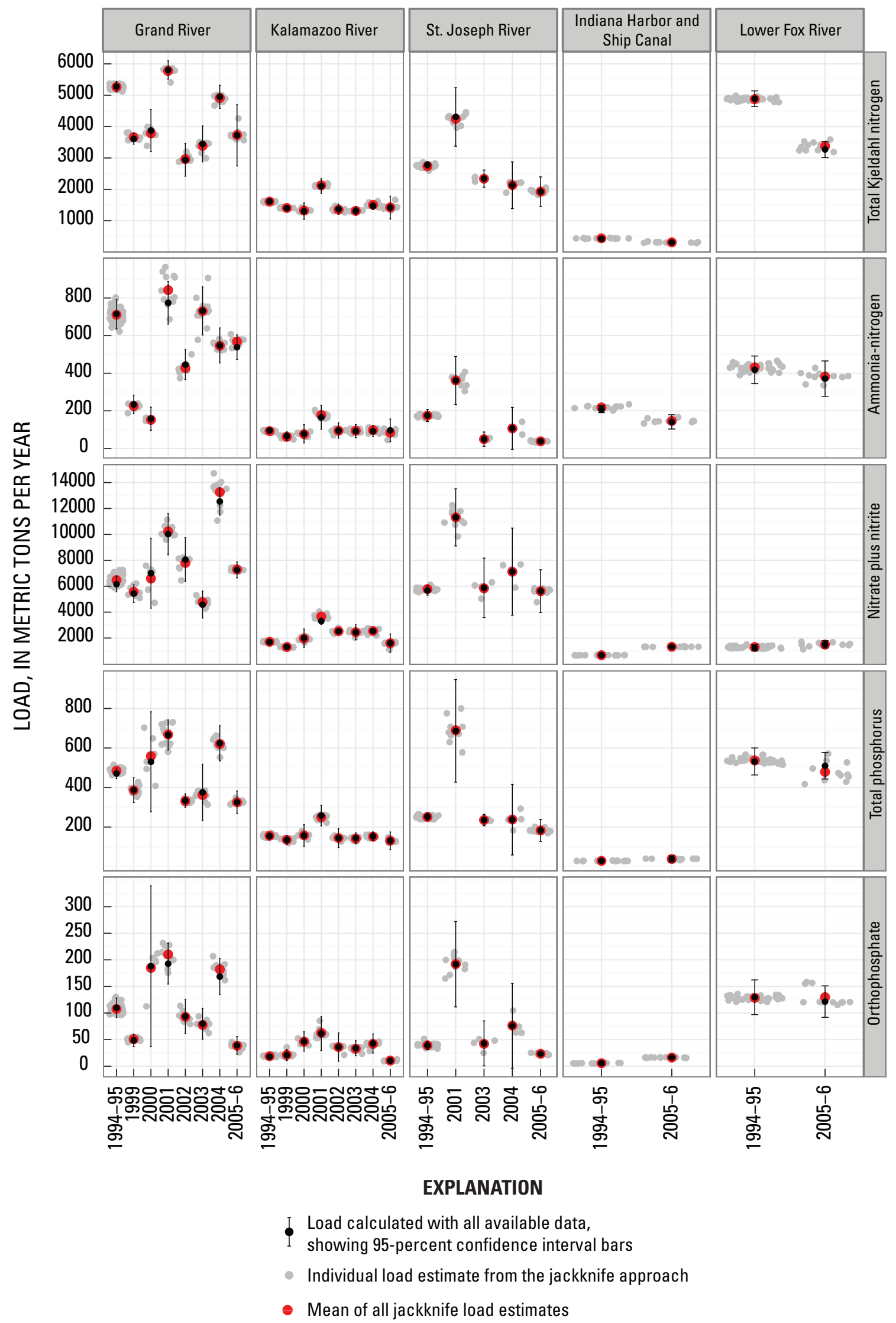

Figure 8. Calculated nutrient loads at five Lake Michigan tributary monitoring sites. (Note differences in y-axis scales among the plots.) 
Again, an example of the influence of regional weather patterns may be seen in the pattern of estimated loads for the three Michigan tributaries. Load estimates for 2001 are almost uniformly greater than the calculated loads before or since that year at the Michigan tributaries. Examination of the hydrographs (fig. 2) shows that although the magnitude of the flows differs greatly between the tributaries, there is a high degree of similarity in the shape of the hydrographs, particularly for the three Michigan tributaries. Mean and annual flows for 2001 were greater than normal long-term values for the Michigan tributaries; the resulting loads are greater than those calculated for years before or after 2001. Flow-normalized loads show much less year-to-year variability than the stratified AutoBeale loads (appendix 5).

There are few obvious trends in annual nutrient loads for any of the five tributaries. The generally higher annual load estimates for the Michigan tributaries observed in 2001 and 2004 appear to be a function of (1) higher flows relative to other years and (2) higher flows in both late spring (May) and late fall (October-December), relative to other years (fig. 2). The increased loads at the Indiana Harbor and Ship Canal for orthophosphate and nitrate plus nitrite are directly related to the significant increases in the concentrations of these constituents.

\section{Mercury}

Estimated annual total mercury loads ranged from $51 \mathrm{~kg} / \mathrm{yr}$ at the Fox River to $2.2 \mathrm{~kg} / \mathrm{yr}$ at the Indiana Harbor and Ship Canal. Total mercury loads and concentrations appear to have decreased since the LMMBP for the Michigan tributaries. Figure 9 summarizes total mercury concentrations at the five tributaries.
The visual trend and the regression analysis both suggest small to moderate decreases in the total mercury concentrations at the Grand, Kalamazoo, and St. Joseph Rivers (table 9). No significant regression models could be constructed for the Fox River and Indiana Harbor and Ship Canal for total mercury; however, the visual patterns of concentration data for the Fox River and the Indiana Harbor and Ship Canal suggest no change.

The annual load estimates for total mercury are uniformly lower relative to the loads estimated during the LMMBP (figs. 10 and 11). Some of the decrease in loads may be explained by the lower flow volumes in the 2005-6 period relative to the LMMBP period; the fact that downward trends in total mercury are also apparent in the flow-normalized annual load estimates (clearest for the Kalamazoo and St. Joseph Rivers, appendix 5) suggests that part of the decrease in loads may be due to environmental change.

There is reason to believe that mercury loads at all sites should be decreasing: wet deposition of mercury appears to be decreasing (Butler and others, 2008). In addition, sediment cleanup activity has taken place at the Fox and Kalamazoo Rivers and at the Indiana Harbor and Ship Canal (U.S. Environmental Protection Agency, 2009c).

Loads for total and dissolved mercury and methylmercury at the Fox River are shown in figure 11. The 2005-6 AutoBeale loads for total methylmercury generated as part of the jackknife iterations are significantly higher than those calculated with all samples retained. The small sample size and the strong seasonal pattern in the data result in very different stratification schemes when a single point is removed, causing the resulting load estimate to increase relative to the load calculated from all available data points.

Table 9. Adjusted R-squared values, p-values, and effect size for total mercury regression models.

[TSS, total suspended solids; ---, variable removed from regression; \#\#\#, no suitable regression model could be found]

\begin{tabular}{|c|c|c|c|c|c|c|c|}
\hline \multirow[b]{2}{*}{ Tributary name } & \multirow{2}{*}{$\begin{array}{c}\text { Adjusted } \\
\text { R-squared } \\
\text { value }\end{array}$} & \multicolumn{4}{|c|}{ Significance of coefficients ( $p$-value) } & \multirow{2}{*}{$\begin{array}{c}\text { Effect } \\
\text { size }\end{array}$} & \multirow[b]{2}{*}{ Interpretation } \\
\hline & & TSS & $\begin{array}{c}\text { Air } \\
\text { temperature }\end{array}$ & Discharge & Time & & \\
\hline Grand River & 0.428 & --- & --- & $2.56 \mathrm{E}-12$ & $1.70 \mathrm{E}-03$ & -0.65 & Small decrease \\
\hline Kalamazoo River & .273 & --- & --- & $7.21 \mathrm{E}-01$ & 2.74E-09 & -1.63 & Moderate decrease \\
\hline St. Joseph River & .517 & --- & --- & 8.57E-11 & $9.76 \mathrm{E}-05$ & -.743 & Small decrease \\
\hline $\begin{array}{l}\text { Indiana Harbor and } \\
\text { Ship Canal }\end{array}$ & \#\#\# & \#\#\# & \#\#\# & \#\#\# & \#\#\# & \#\#\# & \#\#\# \\
\hline Fox River & \#\# & \#\# & \#\# & \#\# & \#\# & \#\#\# & \#\#\# \\
\hline
\end{tabular}



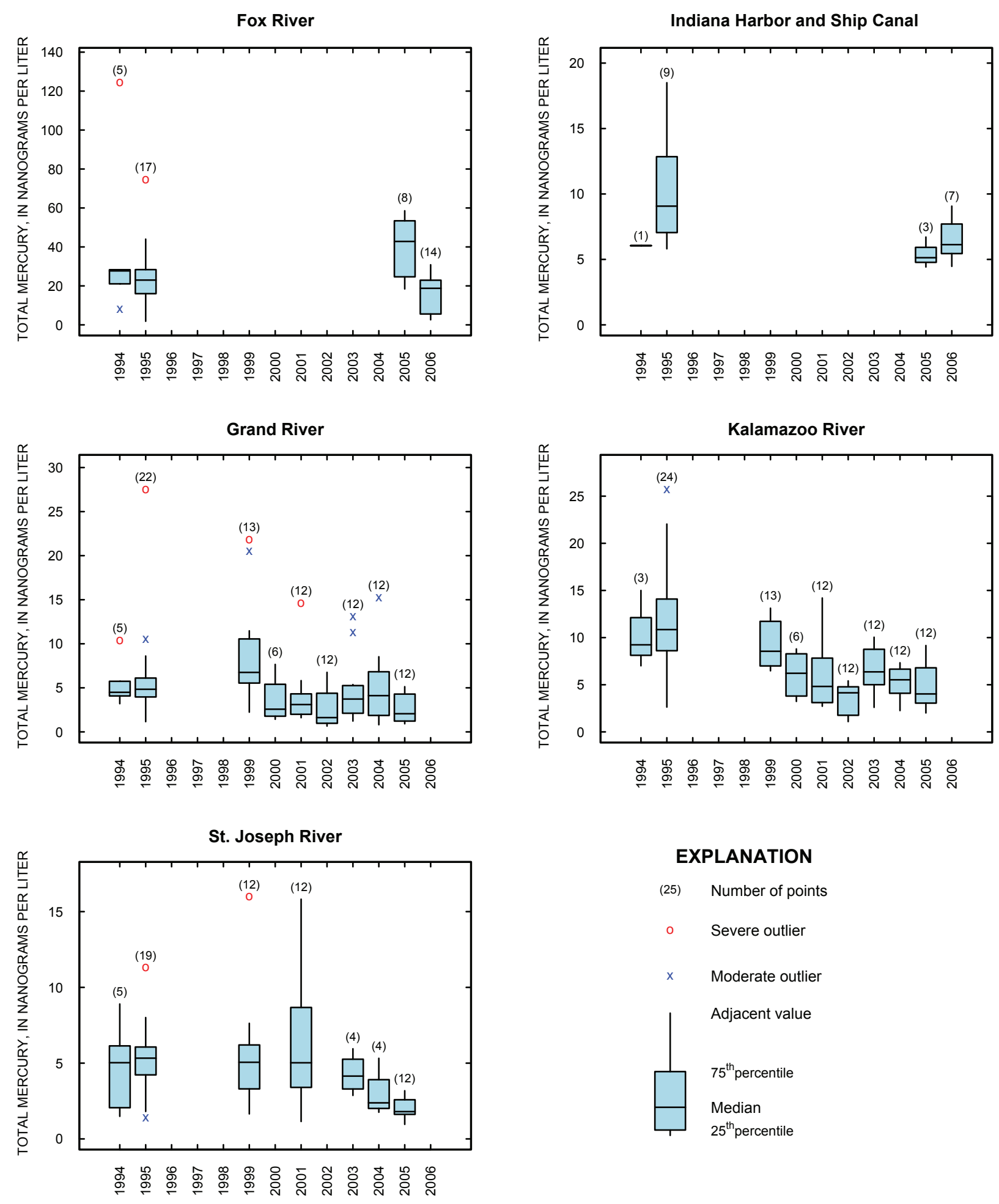

\section{EXPLANATION}

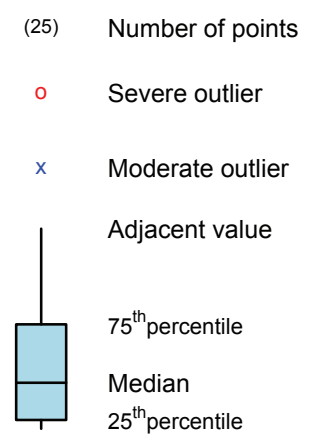

Figure 9. Total mercury concentrations at five Lake Michigan tributary monitoring sites, 1994-2006. (Note differences in $y$-axis scales among the plots.) 


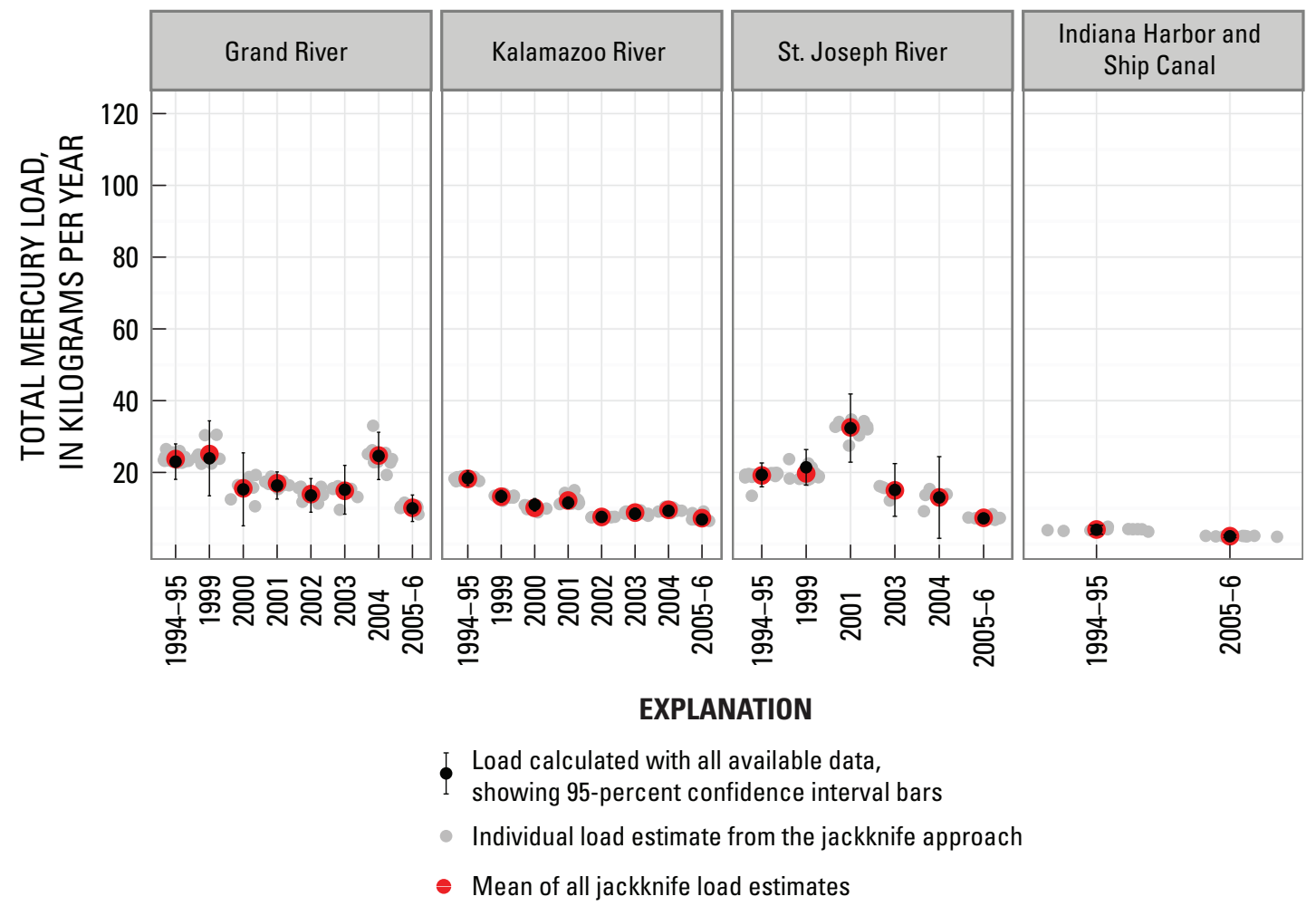

Figure 10. Calculated mercury loads at four Lake Michigan tributary monitoring sites.

- Mean of all jackknife load estimates

Figure 11.

Calculated mercury loads at the Fox River tributary monitoring site.
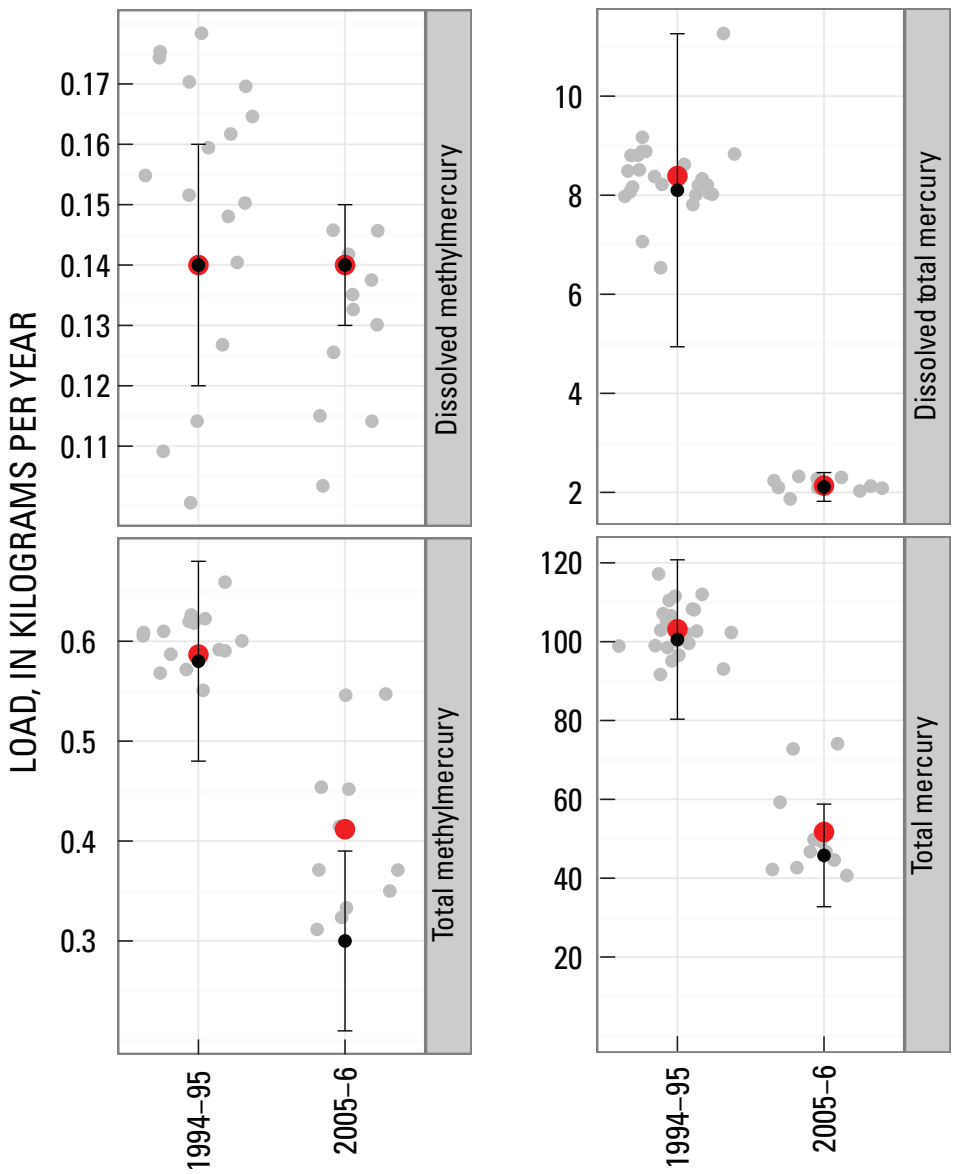

\section{EXPLANATION}

Load calculated with all available data, showing 95-percent confidence interval bars

- Individual load estimate from the jackknife approach

- Mean of all jackknife load estimates 


\section{Polychlorinated Biphenyl}

Estimated annual total polychlorinated biphenyl (PCB) loads ranged from $132 \mathrm{~kg} / \mathrm{yr}$ at the Fox River to $6.2 \mathrm{~kg} / \mathrm{yr}$ at the Grand River. Total PCB concentrations appear to have decreased since the time of the LMMBP at the Michigan tributaries and at the Indiana Harbor and Ship Canal (fig. 12).

Decreases in PCB concentrations were observed at all tributaries except the Fox River. At the Fox River, the highest concentrations of PCB were observed when discharge was low (below the median discharge) and air temperatures were high (relative to the annual mean air temperature). In addition, dredging in Little Lake Butte des Morts on the Fox River was started in 2004 (GW Partners, L.L.C., 2009); dredging as a sediment cleanup option is known to remobilize small masses of contaminants even as large masses of contaminants are removed from the system (Steuer, 2000).

Small decreases in PCB concentrations were found through regression analysis for the three Michigan tributaries (table 10). Moderate decreases in PCB concentrations were found for the Indiana Harbor and Ship Canal. The time-related coefficient was not significant for the Fox River regression.

All estimated PCB loads for 2005-6 were lower than load estimates estimated for the LMMBP (fig. 13). There is good reason to believe that PCB loads at all sites should be decreasing: atmospheric deposition of PCB continues to decrease (Blanchard and others, 2000), and PCB has been banned from use in open systems since 1979 (U.S. Environmental Protection Agency, 2009b). As mentioned previously, some degree of sediment cleanup activity has taken place at the Fox and Kalamazoo Rivers, and at the Indiana Harbor and Ship Canal (U.S. Environmental Protection Agency, 2009c).
One important factor contributing to the lower PCB loads is the difference in river discharge for 2005-6 and 1994-95; in the 2005-6 period, mean and extreme values of discharge generally were lower. However, the apparent downward trend in total PCB concentrations, as well as flow-normalized annual loads (appendix 5), suggest that part of the decrease in loads is due to environmental change.

PCB loads calculated for 2005-6 for the Fox River are lower than those calculated during the LMMBP, a fact that could be largely explained by decreases in total flow volume in 2005-6 relative to the LMMBP. However, examination of the historical, current (2005-6) and simulated total PCB loads for the Fox River suggests that loadings should be decreasing (fig. 14), and that the current loads could be part of this expected downward trend. Simulated PCB loads were calculated from concentration and flow data associated with the noaction scenario generated for the Fox River Remedial Investigation/Feasibility Study (Wisconsin Department of Natural Resources and The RETEC Group, 2002). The no-action scenario run begins in 2000 and was run out to 2020 .

Calculated loads for 2005-6 are well within the range of values simulated with the no-action scenario for 2005-6. A notable pattern apparent in the simulated loads is that even as the overall trend in loading goes downward, year-to-year variability in loads remains high. Ironically, as environmental concentrations decrease over time, greater sampling effort (more samples spread over multiple years) will be required to fully document changing conditions relative to inherent system variability.

Table 10. Adjusted R-squared values, p-values, and effect size for polychlorinated biphenyl (PCB) regression models.

[TSS, total suspended solids; ---, variable removed from regression; ***, either not statistically significant or of no practical significance]

\begin{tabular}{|c|c|c|c|c|c|c|c|}
\hline \multirow[b]{2}{*}{ Tributary name } & \multirow{2}{*}{$\begin{array}{c}\text { Adjusted } \\
\text { R-squared } \\
\text { value }\end{array}$} & \multicolumn{4}{|c|}{ Significance of coefficients ( $p$-value) } & \multirow{2}{*}{$\begin{array}{l}\text { Effect } \\
\text { size }\end{array}$} & \multirow[b]{2}{*}{ Interpretation } \\
\hline & & TSS & $\begin{array}{c}\text { Air } \\
\text { temperature }\end{array}$ & Discharge & Time & & \\
\hline Grand River & 0.552 & $4.22 \mathrm{E}-11$ & --- & 2.45E-01 & $1.54 \mathrm{E}-03$ & -0.72 & Small decrease \\
\hline Kalamazoo River & .658 & 3.43E-06 & $5.15 \mathrm{E}-01$ & $3.14 \mathrm{E}-03$ & $6.70 \mathrm{E}-07$ & -.99 & Small decrease \\
\hline St. Joseph River & .653 & $5.39 \mathrm{E}-04$ & $9.32 \mathrm{E}-05$ & --- & $3.07 \mathrm{E}-02$ & -.74 & Small decrease \\
\hline $\begin{array}{l}\text { Indiana Harbor and } \\
\text { Ship Canal }\end{array}$ & .431 & $1.42 \mathrm{E}-02$ & $3.04 \mathrm{E}-02$ & --- & 4.08E-02 & -1.34 & Moderate decrease \\
\hline Fox River & .819 & $1.79 \mathrm{E}-10$ & $2.85 \mathrm{E}-07$ & 7.57E-02 & $5.06 \mathrm{E}-01$ & .1 & $* * *$ \\
\hline
\end{tabular}


Fox River

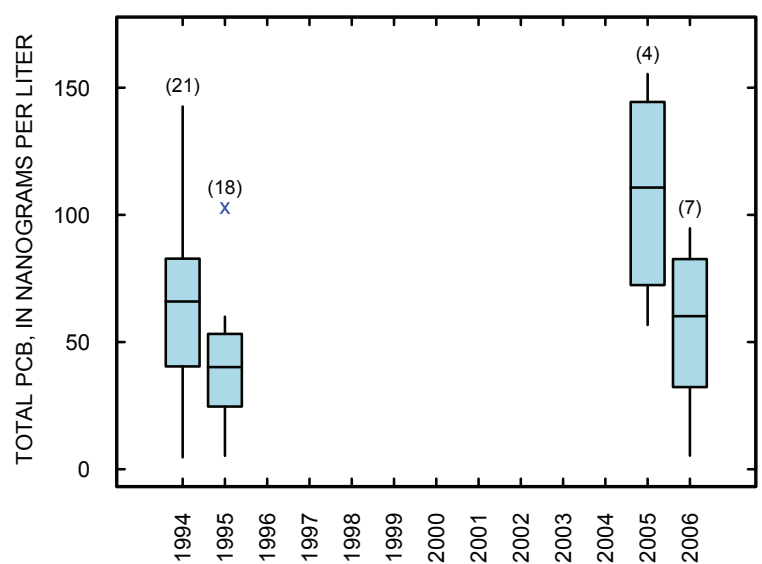

Grand River

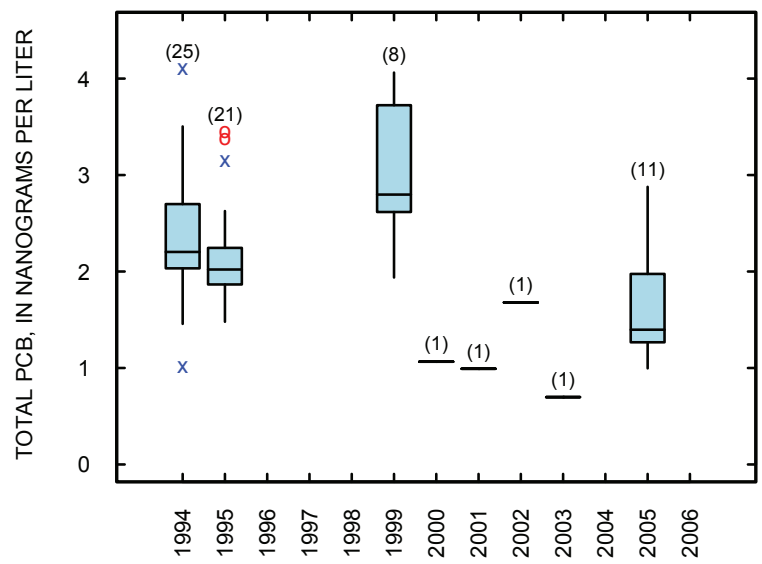

St. Joseph River

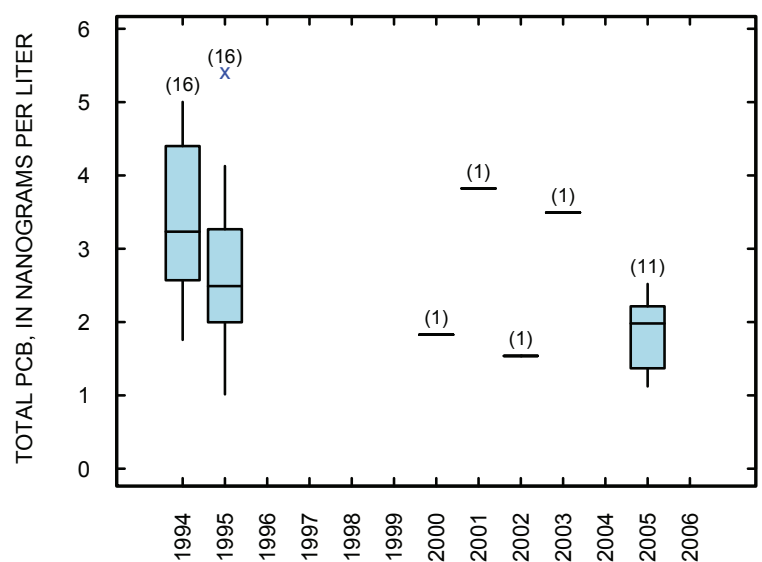

Indiana Harbor and Ship Canal

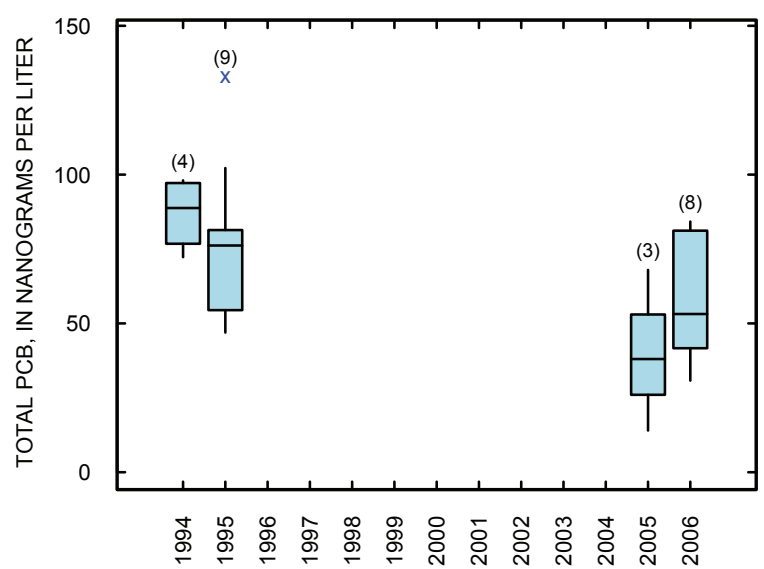

Kalamazoo River

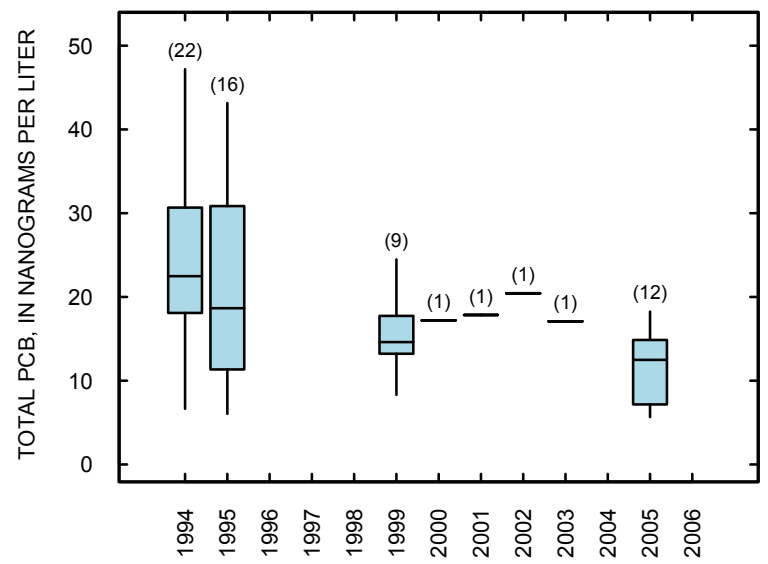

EXPLANATION

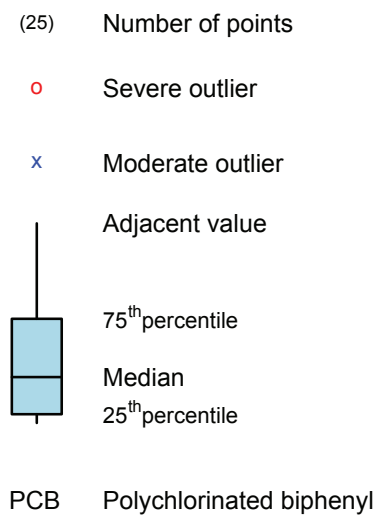

Figure 12. Total polychlorinated biphenyl (PCB) concentrations at five Lake Michigan tributary monitoring sites, 1994-2006. 


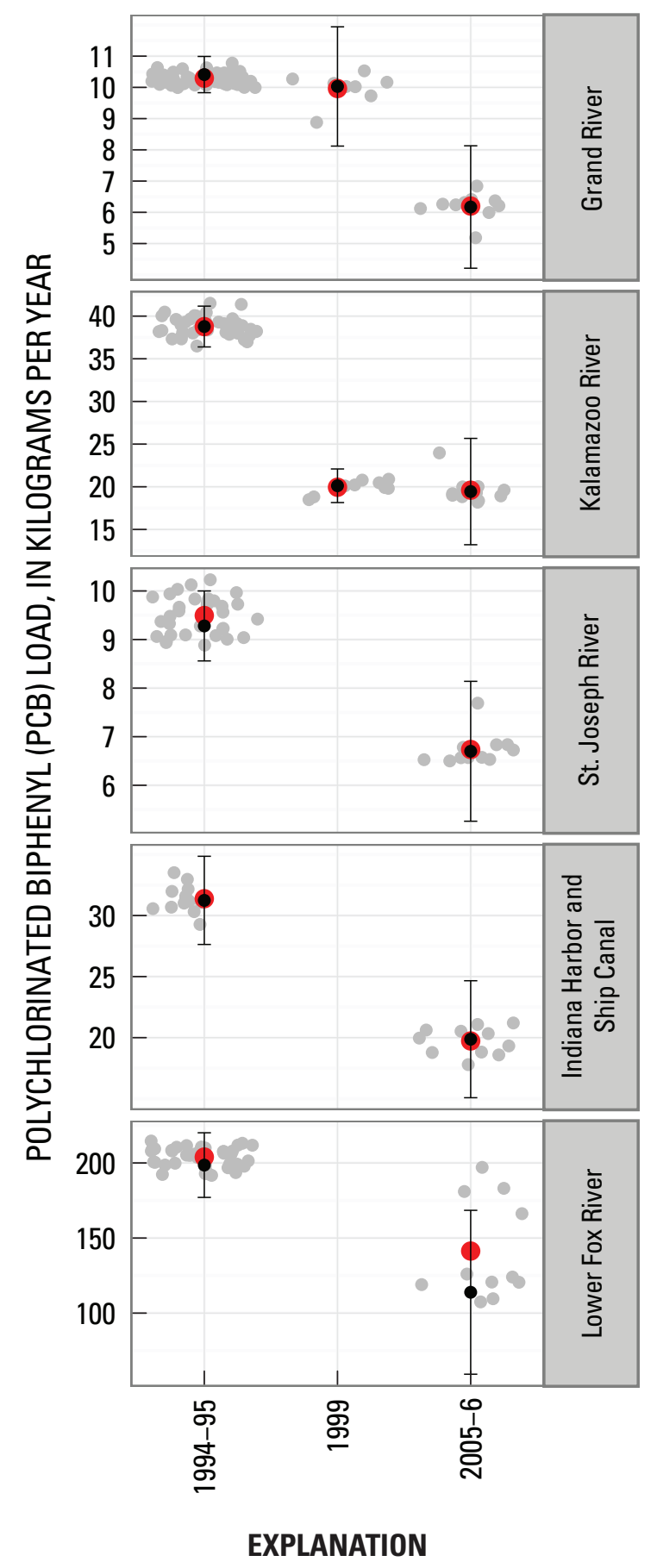

Load calculated with all available data, showing 95-percent confidence interval bars

- Individual load estimate from the jackknife approach

- Mean of all jackknife load estimates

Figure 13. Calculated polychlorinated biphenyl (PCB) loads at five Lake Michigan tributary monitoring sites. 


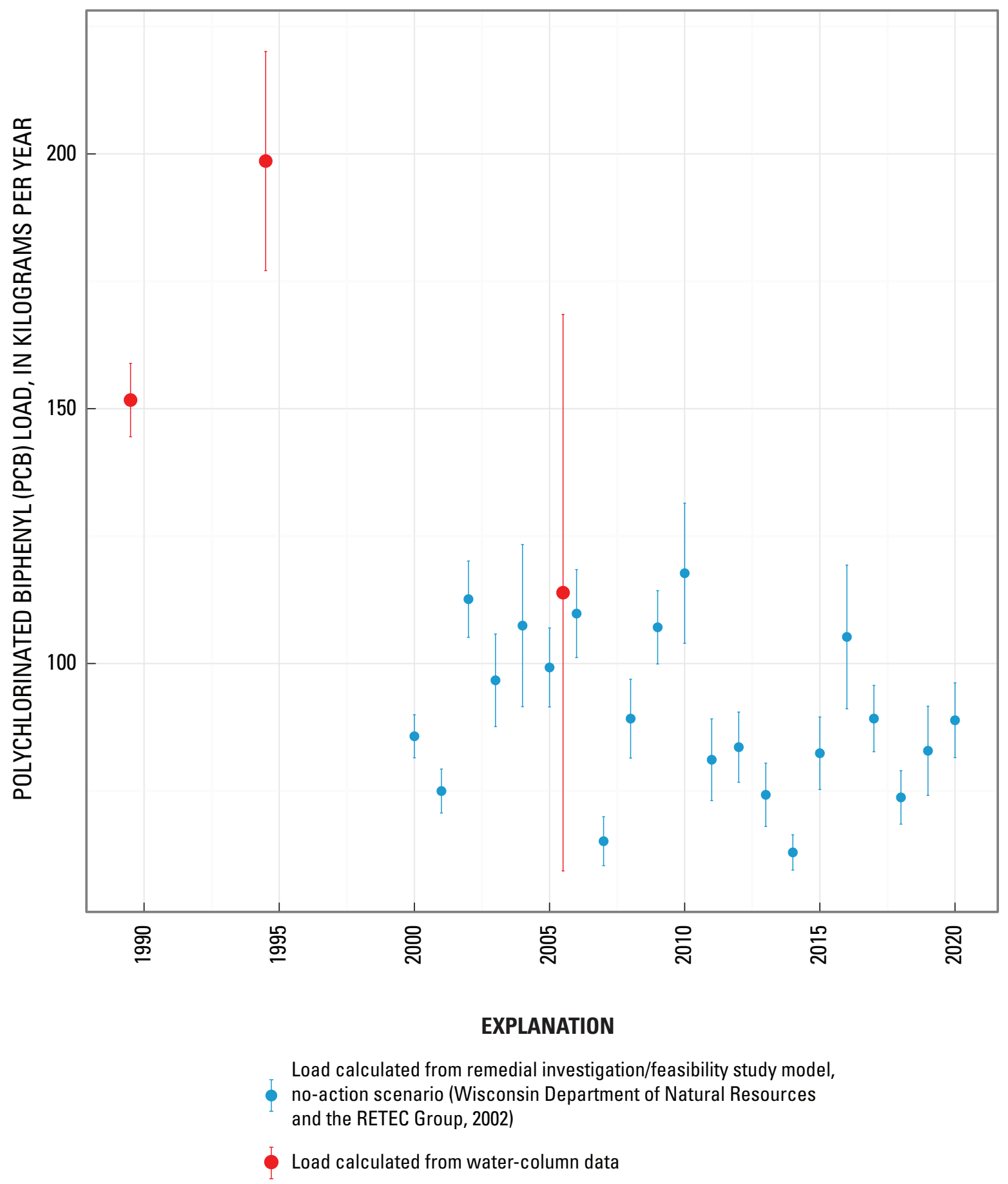

Figure 14. Calculated total polychlorinated biphenyl (PCB) loads for the Lower Fox River, 1989 to 2006. 


\section{Summary and Conclusions}

Water samples were collected in 2005 and 2006 to generate concentration data and load estimates for 5 nutrients, total mercury, and total PCB at 5 of the original 11 Lake Michigan Mass Balance Project sampling sites. New concentration datasets were generated as part of the current project for the Fox River and for the Indiana Harbor and Ship Canal. Concentration data for the Grand, Kalamazoo, and St. Joseph Rivers were obtained through sampling efforts coordinated by the Michigan Department of Environmental Quality.

Loads for each of the tributaries were calculated by means of Beale's time-stratified ratio estimator method (Richards, 1998). Uncertainty in load estimates due to the structure of the sampling scheme employed was assessed by means of a jackknife analysis. Results of the jackknife analysis suggest that more intensive sampling may be required in the future, particularly on the Fox and Grand Rivers, in order to reduce the bias and increase the precision of the estimated load.

Comparison of 2005-6 data to the LMMBP data shows the following changes:

- small to moderate increases in total phosphorus and orthophosphate concentrations at the Grand River;

- moderate to large increases in total phosphorus and orthophosphate concentrations at the Indiana Harbor and Ship Canal;

- small to large increases in nitrate plus nitrite concentrations at the Grand and Kalamazoo Rivers, and at the Indiana Harbor and Ship Canal;

- small to moderate decreases in concentrations of total mercury at the Grand, Kalamazoo, and St. Joseph Rivers; and

- small to moderate decreases in concentrations of total PCB at the Grand, Kalamazoo, and St. Joseph Rivers and at the Indiana Harbor and Ship Canal.

Estimated annual total mercury loads during 2005-6 ranged from $51 \mathrm{~kg} / \mathrm{yr}$ at the Fox River to $2.2 \mathrm{~kg} / \mathrm{yr}$ at the Indiana Harbor and Ship Canal. Estimated total polychlorinated biphenyl (PCB) loads during 2005-6 ranged from $132 \mathrm{~kg} / \mathrm{yr}$ at the Fox River to $6.2 \mathrm{~kg} / \mathrm{yr}$ at the Grand River.

In general, the calculated loads for the 2005-6 are lower than those calculated for the LMMBP. Decreases in loads are due to a combination of factors, including differences in streamflow between the two time periods, smaller sample sizes relative to the LMMBP, and actual environmental changes.

\section{References Cited}

Blanchard, P., Audette, C., Hulting, M., Basu, I., Brice, K., Chan, C., Dryfhout-Clark, H., Froude, F., Hites, R., and Neilson, M., 2000, Atmospheric deposition of toxic substances to the Great Lakes-IADN results through 2000: Environment Canada and U.S. Environmental Protection Agency, accessed March 2009 at $h t t p: / / w w w . m s c . e c . g c . c a /$ iadn/resources/resources_e.html

Butler, T.J., Cohen, M.D., Vermeylen, F.M., Likens, G.E., Schmeltz, D., and Artz, R.S., 2008, Regional precipitation mercury trends in the eastern USA, 1998-2005-Declines in the Northeast and Midwest, no trend in the Southeast: Atmospheric Environment, v. 42, no. 7, p. 1582-1592.

Charbonneau, P., 2002, Release notes for PIKAIA 1.2, NCAR Technical Note 451+ STR: Boulder, Colo., High Altitude Observatory, National Center for Atmospheric Research, $40 \mathrm{p}$.

Charbonneau, P., and Knapp, B., 1995, A user's guide to PIKAIA 1.0, NCAR Technical Note 418+ IA: Boulder, Colo., High Altitude Observatory, National Center for Atmospheric Research, 109 p.

Cochran, W.G., 1977, Sampling techniques (3d ed.): New York, Wiley, 428 p.

Cohen, J., 1962, The statistical power of abnormal-social psychological research - A review: Journal of Abnormal and Social Psychology, v. 65, p. 145.

De Wild, J.F., Olson, M.L., and Olund, S.D., 2002, Determination of methyl mercury by aqueous phase ethylation, followed by gas chromatographic separation with cold vapor atomic fluorescence detection: U.S. Geological Survey Open-File Report 01-445, 14 p.

Dolan, D.M., Yui, A.K., and Geist, R.D., 1981, Evaluation of river load estimation methods for total phosphorus: Journal of Great Lakes Research, v. 7, no. 3, p. 207-214.

Efron, B., and Tibshirani, R., 1993, An introduction to the bootstrap-Monographs on statistics and applied probability: Boca Raton, Fla., CRC Press, 456 p.

Fox, J., 2008, Applied regression analysis and generalized linear models: Thousand Oaks, Calif., Sage Publications, $624 \mathrm{p}$.

GW Partners, L.L.C., 2009, Little Lake cleanup facts: Little

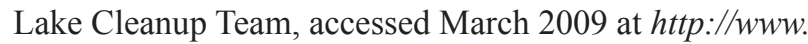
littlelakecleanup.com/cleanupfacts.html 
Hinkley, D.V., 1977, Jackknife confidence limits using Student $\mathrm{t}$ approximations: Biometrika, v. 64, no. 1, p. 21-28.

McFarland, V.A., and Clarke, J.U., 1989, Environmental occurrence, abundance, and potential toxicity of polychlorinated biphenyl congeners-Considerations for a congenerspecific analysis: Environmental Health Perspectives, v. 81, p. 225.

Michigan Department of Environmental Quality, 2008, Michigan water chemistry monitoring-Great Lakes tributaries, accessed February 2009 at http://www.michigan.gov/ documents/deq/wb-swas-9805tribreport_222804_7.pdf

Mosteller, F., and Tukey, J.W., 1977, Data analysis and regression-A second course in statistics: Reading, Mass., Addison-Wesley, 588 p.

O'Brien, R.M., 2007, A caution regarding rules of thumb for variance inflation factors: Quality and Quantity, v. 41, no. 5, p. 673-690.

Porterfield, George, 1972, Computation of fluvial-sediment discharge: U.S. Geological Survey Techniques of WaterResources Investigations, book 3, chap. C3, 66 p.

Rediske, R., Bertin, C., Blunt, J., and Qi, M., 1999, Preliminary investigation of the extent of sediment contamination in the Lower Grand River: U.S. Environmental Protection Agency, accessed March 2009 at http://www.epa.gov/glnpo/ sediment/GrandRiver/index.html

Richards, R.P., 1998, Estimation of pollutant loads in rivers and streams - A guidance document for NPS programs: Project report prepared under Grant X998397-01-0, U.S. Environmental Protection Agency, Region VIII, 108 p.

Richards, R.P., 1999, User's guide for Autobeale-An implementation of the Beale Ratio Estimator Load Calculation Program: Tiffin, Ohio, Heidelberg University, National Center for Water Quality Research, [8] p.

Richards, R.P., and Holloway, J., 1987, Monte Carlo studies of sampling strategies for estimating tributary loads: Water Resources Research, v. 23, no. 10, p. 1939-1948.

Risch, M.R., 2005, Mercury in the Grand Calumet River/ Indiana Harbor Canal and Lake Michigan, Lake County, Indiana, August 2001 and May 2002: U.S. Geological Survey Scientific Investigations Report 2005-5034, 55 p.

Sonzogni, W.C., Monteith, T.J., Bach, W.N., and Hughes, V.G., 1978, United States Great Lakes tributary loadingsInternational Reference Group on Great Lakes pollution from land use activities: Washington, D.C., International Joint Commission, 187 p.
Steuer, J.J., 2000, A mass-balance approach for assessing PCB movement during remediation of a PCB-contaminated deposit on the Fox River, Wisconsin: U.S. Geological Survey Water-Resources Investigations Report 2000-4245, 8 p.

U.S. Environmental Protection Agency, 1997, Lake Michigan Mass Budget/Mass Balance Workplan: Great Lakes National Program Office, accessed February 2009 at http:// www.epa.gov/greatlakes/lmmb/workplan/index.html

U.S. Environmental Protection Agency, 1997, Lake Michigan Mass Balance Methods Compendium, accessed January 2009 at http://www.epa.gov/greatlakes/lmmb/ methods/\#Methods

U.S. Environmental Protection Agency, 1999, Quality Assurance Plan For Mathematical Modeling: Grosse Ile, Mich., Great Lakes National Program Office, Large Lakes Research Station, 233 p.

U.S. Environmental Protection Agency, 2006, Results of the Lake Michigan Mass Balance Project: Polychlorinated Biphenyls Modeling Report: Large Lakes Research Station, accessed March 2009 at http://www.epa.gov/med/grosseile site/LMMBP/pcb-report.html

U.S. Environmental Protection Agency, 2008, Lake Michigan Lakewide Management Plan 2008, accessed March 2009 at http:/lepa.gov/greatlakes/lamp/lm_2008/index.html

U.S. Environmental Protection Agency, 2009, Great Lakes areas of concern, accessed February 2009 at http:/lepa.gov/ greatlakes/aoc/index.html

U.S. Environmental Protection Agency, 2009, Basic information-Polychlorinated biphenyls (PCBs), accessed March 2009 at http://www.epa.gov/epawaste/hazard/tsd/pcbs/pubs/ about.htm

U.S. Environmental Protection Agency, 2009, Great Lakes contaminated sediments, accessed May 2009 at http://epa. gov/greatlakes/sediment/remed/index.html

U.S. Geological Survey, 2008, Lake Michigan Monitoring Coordination Council, accessed June 2009 at http:// wi.water.usgs.gov/lmmcc/index.html

Wisconsin Department of Natural Resources, 2002, White Paper No. 4, Dams in Wisconsin and on the Lower Fox River-Response to comments by the Fox River Group: Madison, Wis., [11] p.

Wisconsin Department of Natural Resources and The RETEC Group, 2002, Final Model Documentation Report, RETEC Project Number WISCN-14414-262: Madison, Wis., and Seattle, Wash., accessed January 2010 at http://nr.wi.gov/ org/water/wm/foxriver/documents/modeldocs/final_model_ doc.pdf 
Wisconsin State Laboratory of Hygiene, 1996, PCBs and pesticides in surface water by XAD-2 resin extraction, in Lake Michigan Mass Balance Methods Compendium, U.S. Environmental Protection Agency, v. 2, accessed March 2010 at http://www.epa.gov/glnpo/lmmb/methods/sec1293.pdf
Young, T.C., DePinto, J.V., and Heidtke, T.M., 1988, Factors affecting the efficiency of some estimators of fluvial total phosphorus load: Water Resources Research, v. 24, no. 9, p. 1535-1540. 
Appendix 1. Analytical Methods 


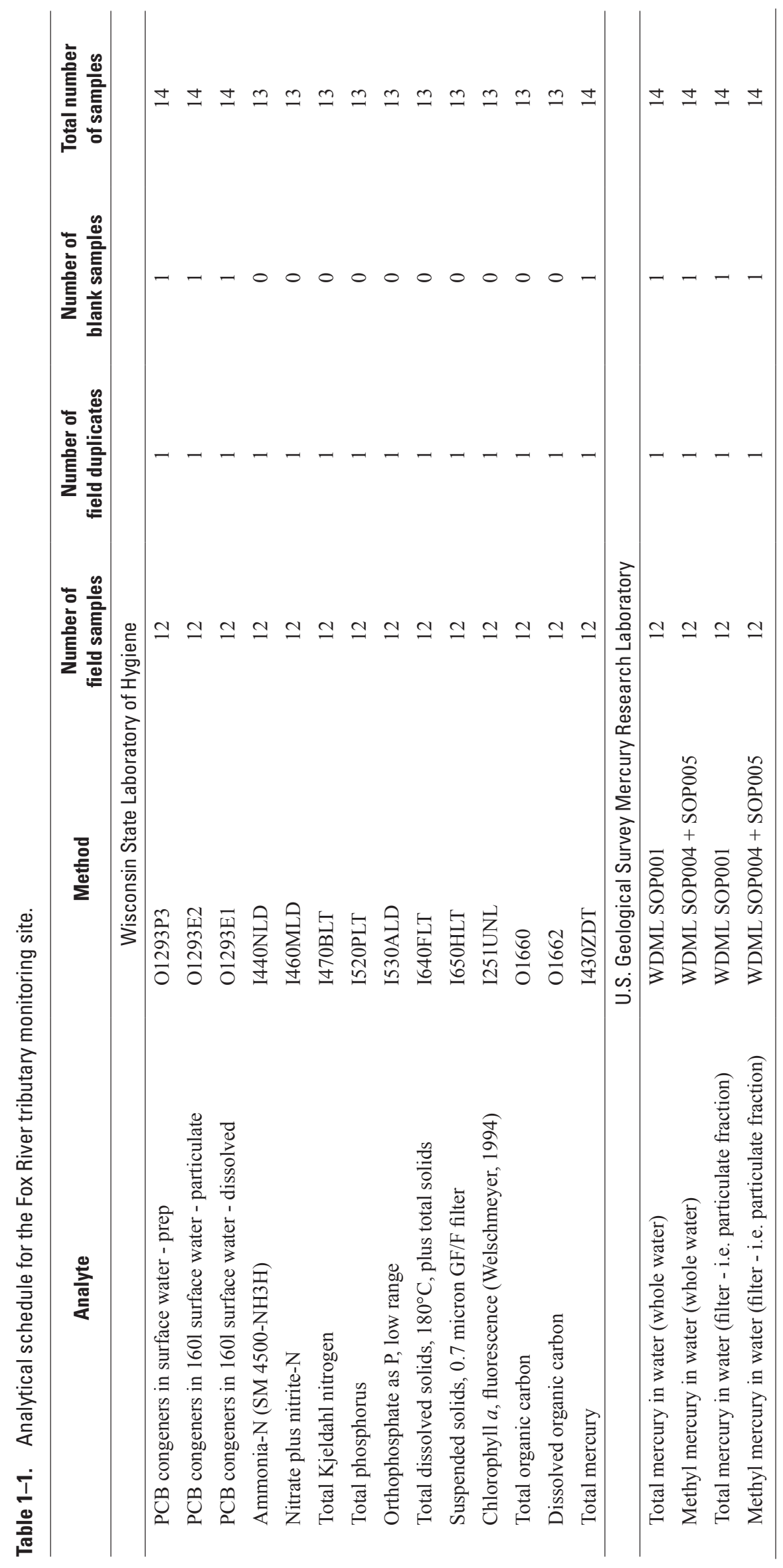



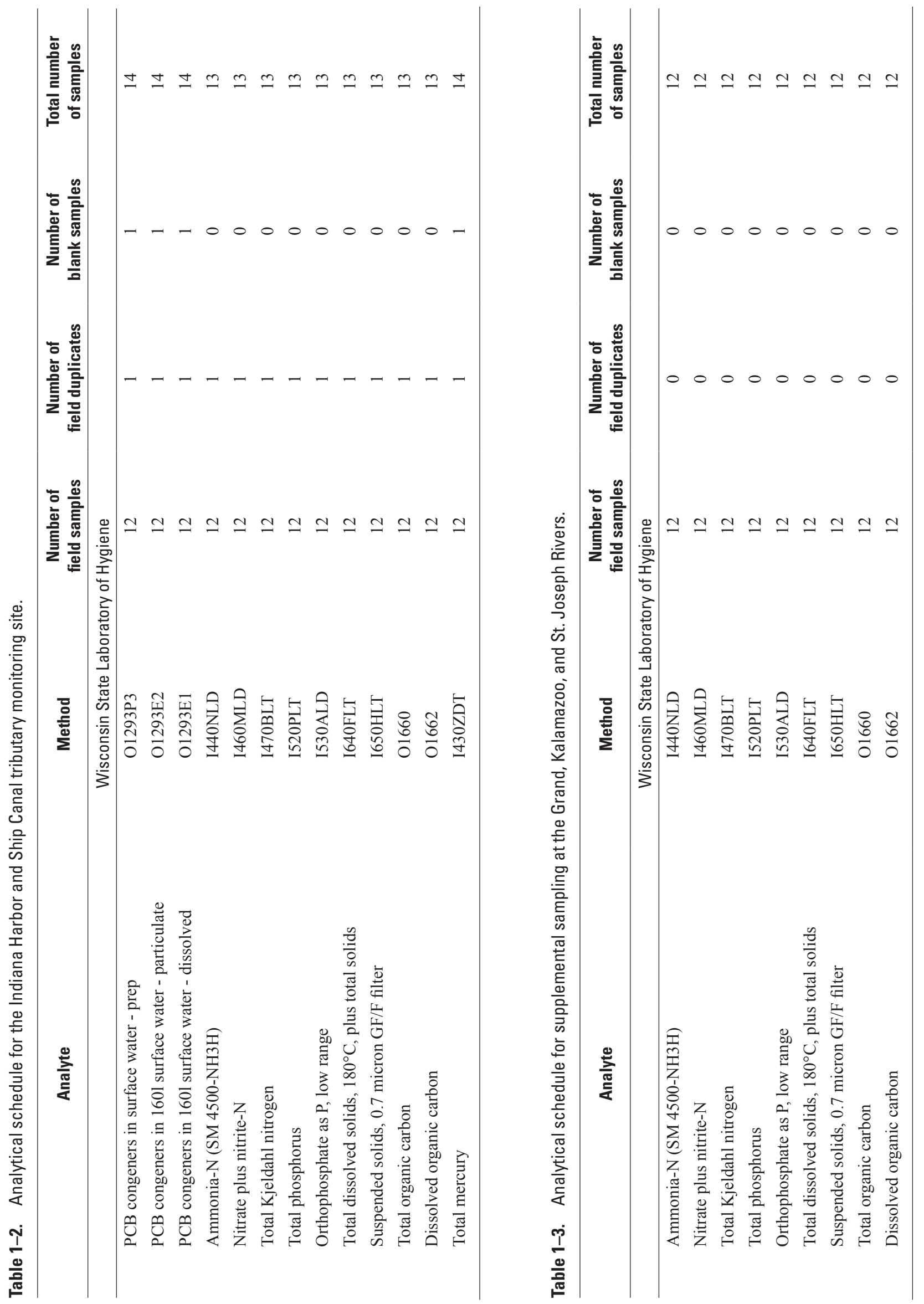
This page is intentionally blank. 
Appendix 2. Quality-Control Data Tables 
Table 2-1. Field replicate results for the Grand River at Eastmanville, Michigan.

[Laboratory results in milligrams per liter; <, less than; ---, not determined]

\begin{tabular}{|c|c|c|c|}
\hline Sample date & $\begin{array}{l}\text { Michigan Department } \\
\text { of Environmental Quality }\end{array}$ & $\begin{array}{c}\text { Wisconsin State } \\
\text { Laboratory of Hygiene }\end{array}$ & $\begin{array}{c}\text { Relative percent } \\
\text { difference }\end{array}$ \\
\hline \multicolumn{4}{|c|}{ Phosphorus } \\
\hline $10 / 04 / 2005$ & 0.086 & 0.103 & 18.0 \\
\hline $10 / 26 / 2005$ & .082 & .085 & 3.6 \\
\hline $11 / 21 / 2005$ & .060 & .118 & 65.2 \\
\hline \multicolumn{4}{|c|}{ Phosphorus, orthophosphate as Phosphorus } \\
\hline $10 / 04 / 2005$ & 0.003 & 0.003 & 0.0 \\
\hline $10 / 26 / 2005$ & .002 & .006 & 100.0 \\
\hline $11 / 21 / 2005$ & .025 & .020 & 22.2 \\
\hline \multicolumn{4}{|c|}{ Nitrogen, ammonia $\left(\mathrm{NH}_{3}\right)$ as Nitrogen } \\
\hline $10 / 04 / 2005$ & 0.015 & $<0.015$ & --- \\
\hline $10 / 26 / 2005$ & .270 & .247 & 8.9 \\
\hline $11 / 21 / 2005$ & .133 & .120 & 10.3 \\
\hline \multicolumn{4}{|c|}{ Nitrogen, Kjeldahl, as Nitrogen } \\
\hline $10 / 04 / 2005$ & 0.96 & 1.03 & 7.0 \\
\hline $10 / 26 / 2005$ & .90 & .85 & 5.7 \\
\hline $11 / 21 / 2005$ & .65 & .61 & 6.3 \\
\hline \multicolumn{4}{|c|}{ Nitrate plus nitrite, as Nitrogen } \\
\hline $10 / 04 / 2005$ & 1.06 & 1.33 & 22.6 \\
\hline $10 / 26 / 2005$ & 1.35 & 1.40 & 3.6 \\
\hline $11 / 21 / 2005$ & 1.59 & 1.62 & 16.8 \\
\hline
\end{tabular}


Table 2-2. Field replicate results for the Kalamazoo River at 57th Street.

[Laboratory results in milligrams per liter; *, result is approximate because of interferences; ,--- not determined; ND, not detected]

\begin{tabular}{|c|c|c|c|}
\hline Sample date & $\begin{array}{l}\text { Michigan Department } \\
\text { of Environmental Quality }\end{array}$ & $\begin{array}{c}\text { Wisconsin State } \\
\text { Laboratory of Hygiene }\end{array}$ & $\begin{array}{l}\text { Relative percent } \\
\text { difference }\end{array}$ \\
\hline \multicolumn{4}{|c|}{ Phosphorus } \\
\hline $09 / 27 / 2005$ & 0.069 & 0.069 & 0.0 \\
\hline $10 / 18 / 2005$ & .056 & .053 & 5.5 \\
\hline $11 / 02 / 2005$ & .039 & $* .047$ & --- \\
\hline $11 / 22 / 2005$ & .040 & .091 & 77.9 \\
\hline \multicolumn{4}{|c|}{ Phosphorus, orthophosphate as Phosphorus } \\
\hline 09/27/2005 & 0.005 & 0.004 & 22.2 \\
\hline $10 / 18 / 2005$ & .002 & .003 & 40.0 \\
\hline $11 / 02 / 2005$ & .001 & $* .002$ & --- \\
\hline $11 / 22 / 2005$ & .012 & .010 & 18.2 \\
\hline \multicolumn{4}{|c|}{ Nitrogen, ammonia $\left(\mathrm{NH}_{3}\right)$ as Nitrogen } \\
\hline $09 / 27 / 2005$ & 0.029 & ND & --- \\
\hline $10 / 18 / 2005$ & .004 & ND & --- \\
\hline $11 / 02 / 2005$ & .026 & .024 & 8.0 \\
\hline $11 / 22 / 2005$ & .078 & .063 & 21.3 \\
\hline \multicolumn{4}{|c|}{ Nitrogen, Kjeldahl, as Nitrogen } \\
\hline $09 / 27 / 2005$ & 0.770 & 0.610 & 23.2 \\
\hline $10 / 18 / 2005$ & .580 & .700 & 18.8 \\
\hline $11 / 02 / 2005$ & .500 & .500 & .0 \\
\hline $11 / 22 / 2005$ & .480 & .400 & 18.2 \\
\hline \multicolumn{4}{|c|}{ Nitrate plus nitrite, as Nitrogen } \\
\hline 09/27/2005 & 0.840 & 0.866 & 3.0 \\
\hline $10 / 18 / 2005$ & 1.040 & 1.090 & 4.7 \\
\hline $11 / 02 / 2005$ & 1.200 & 1.230 & 2.5 \\
\hline $11 / 22 / 2005$ & 1.280 & 1.300 & 1.6 \\
\hline
\end{tabular}


Table 2-3. Field replicate results for the St. Joseph River at St. Joseph, Michigan.

[Laboratory results in milligrams per liter; *, result is approximate because of interferences; ,--- not determined; ND, not detected]

\begin{tabular}{|c|c|c|c|}
\hline Sample date & $\begin{array}{l}\text { Michigan Department } \\
\text { of Environmental Quality }\end{array}$ & $\begin{array}{l}\text { Wisconsin State } \\
\text { Laboratory of Hygiene }\end{array}$ & $\begin{array}{l}\text { Relative percent } \\
\text { difference }\end{array}$ \\
\hline \multicolumn{4}{|c|}{ Phosphorus } \\
\hline 09/29/2005 & 0.065 & 0.072 & 10.2 \\
\hline $10 / 19 / 2005$ & .042 & .047 & 11.2 \\
\hline $11 / 03 / 2005$ & .054 & $* .063$ & --- \\
\hline $11 / 16 / 2005$ & .042 & $* .116$ & --- \\
\hline \multicolumn{4}{|c|}{ Phosphorus, orthophosphate as Phosphorus } \\
\hline 09/29/2005 & 0.024 & 0.020 & 18.2 \\
\hline $10 / 19 / 2005$ & .017 & .021 & 21.1 \\
\hline $11 / 03 / 2005$ & .026 & $* .031$ & --- \\
\hline $11 / 16 / 2005$ & .013 & .014 & 7.4 \\
\hline \multicolumn{4}{|c|}{ Nitrogen, ammonia $\left(\mathrm{NH}_{3}\right)$ as Nitrogen } \\
\hline 09/29/2005 & 0.046 & 0.035 & 27.2 \\
\hline $10 / 19 / 2005$ & .021 & .025 & 17.4 \\
\hline $11 / 03 / 2005$ & .005 & ND & --- \\
\hline $11 / 16 / 2005$ & .018 & ND & --- \\
\hline \multicolumn{4}{|c|}{ Nitrogen, Kjeldahl, as Nitrogen } \\
\hline $09 / 29 / 2005$ & 0.44 & 0.55 & 22.2 \\
\hline $10 / 19 / 2005$ & .32 & .27 & 16.9 \\
\hline $11 / 03 / 2005$ & .31 & .40 & 25.4 \\
\hline $11 / 16 / 2005$ & .37 & .45 & 19.5 \\
\hline \multicolumn{4}{|c|}{ Nitrate plus nitrite, as Nitrogen } \\
\hline 09/29/2005 & 1.36 & 1.37 & 0.7 \\
\hline $10 / 19 / 2005$ & 1.44 & 1.49 & 3.4 \\
\hline $11 / 03 / 2005$ & 1.63 & 1.68 & 3.3 \\
\hline $11 / 16 / 2005$ & 1.62 & 1.69 & 4.2 \\
\hline
\end{tabular}


Appendix 3. Data Tables 
Table 3-1. Concentration data for the Grand River near Riverside Park, Ottawa County, Michigan (04119400).

$\left[\mathrm{m}^{3} / \mathrm{s}\right.$, cubic meters per second; $\mathrm{mg} / \mathrm{L}$, milligrams per liter; ng/L, nanograms per liter; <, less than; ---, not determined]

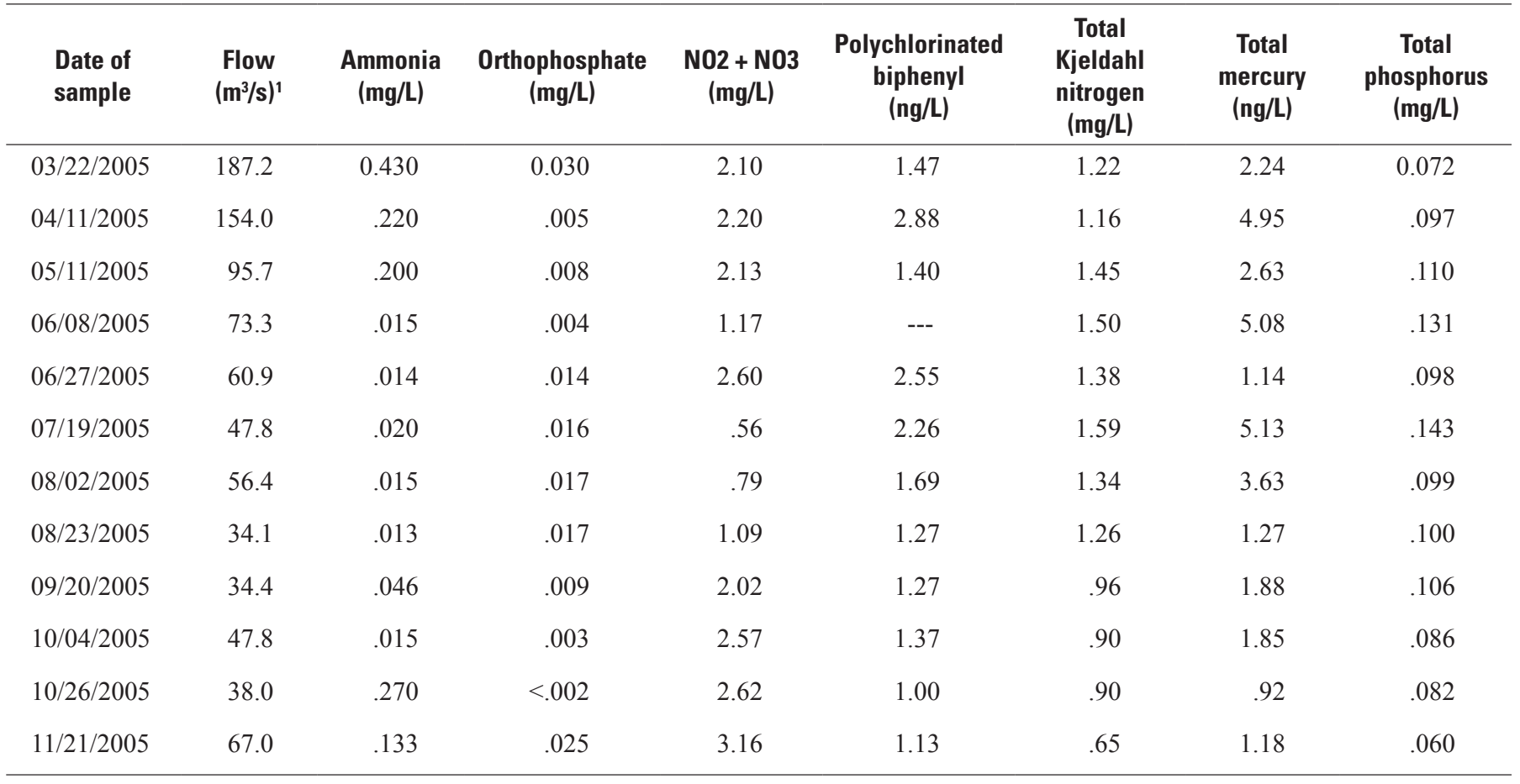

${ }^{1}$ Flow estimated from the Grand River at Grand Rapids, Michigan, streamgaging station (04119000).

Table 3-2. Concentration data for the Kalamazoo River near New Richmond, Michigan (04108660).

$\left[\mathrm{m}^{3} / \mathrm{s}\right.$, cubic meters per second; $\mathrm{mg} / \mathrm{L}$, milligrams per liter; $\mathrm{ng} / \mathrm{L}$, nanograms per liter]

\begin{tabular}{|c|c|c|c|c|c|c|c|c|}
\hline $\begin{array}{l}\text { Date of } \\
\text { sample }\end{array}$ & $\begin{array}{l}\text { Flow } \\
\left(\mathrm{m}^{3} / \mathrm{s}\right)^{1}\end{array}$ & $\begin{array}{c}\text { Ammonia } \\
\text { (mg/L) }\end{array}$ & $\begin{array}{l}\text { Orthophosphate } \\
\text { (mg/L) }\end{array}$ & $\begin{array}{c}\mathrm{NO2}+\mathrm{NO3} \\
(\mathrm{mg} / \mathrm{L})\end{array}$ & $\begin{array}{l}\text { Polychlorinated } \\
\text { biphenyl } \\
\text { (ng/L) }\end{array}$ & $\begin{array}{c}\text { Total } \\
\text { Kjeldahl } \\
\text { nitrogen } \\
\text { (mg/L) }\end{array}$ & $\begin{array}{c}\text { Total } \\
\text { mercury } \\
\text { (ng/L) }\end{array}$ & $\begin{array}{c}\text { Total } \\
\text { phosphorus } \\
\text { (mg/L) }\end{array}$ \\
\hline $03 / 21 / 2005$ & 95.8 & 0.051 & 0.009 & 1.68 & 5.65 & 0.55 & 3.48 & 0.038 \\
\hline $05 / 04 / 2005$ & 54.5 & .010 & .003 & .62 & 13.39 & .98 & 3.04 & .085 \\
\hline 06/28/2005 & 35.3 & .101 & .012 & .32 & 15.65 & 1.22 & 7.30 & .118 \\
\hline 07/20/2005 & 44.0 & .193 & .003 & .44 & 18.25 & 1.36 & 9.16 & .132 \\
\hline 08/03/2005 & 40.5 & .062 & .006 & .50 & 14.08 & .93 & 6.50 & .085 \\
\hline 08/24/2005 & 29.8 & .045 & .005 & .60 & 12.88 & .77 & 5.84 & .123 \\
\hline $10 / 18 / 2005$ & 29.4 & .004 & .002 & 1.04 & 9.12 & .58 & 3.06 & .056 \\
\hline $11 / 02 / 2005$ & 36.4 & .026 & .001 & 1.20 & 6.88 & .50 & 2.24 & .039 \\
\hline $11 / 22 / 2005$ & 28.8 & .078 & .012 & 1.28 & 6.00 & .48 & 2.01 & .040 \\
\hline
\end{tabular}

${ }^{1}$ Flow estimated from the Kalamazoo River at Comstock, Michigan, streamgaging station (04106000). 
Table 3-3. Concentration data for the St. Joseph River near Zollar Drive, Benton Harbor, Michigan (STORET 110628).

$\left[\mathrm{m}^{3} / \mathrm{s}\right.$, cubic meters per second; $\mathrm{mg} / \mathrm{L}$, milligrams per liter; ng/L, nanograms per liter; ---, not determined]

\begin{tabular}{|c|c|c|c|c|c|c|c|c|}
\hline $\begin{array}{l}\text { Date of } \\
\text { sample }\end{array}$ & $\begin{array}{l}\text { Flow } \\
\left(\mathrm{m}^{3} / \mathrm{s}\right)^{1}\end{array}$ & $\begin{array}{c}\text { Ammonia } \\
\text { (mg/L) }\end{array}$ & $\begin{array}{l}\text { Orthophosphate } \\
\text { (mg/L) }\end{array}$ & $\begin{array}{c}\mathrm{NO2}+\mathrm{NO3} \\
(\mathrm{mg} / \mathrm{L})\end{array}$ & $\begin{array}{l}\text { Polychlorinated } \\
\text { biphenyl } \\
\text { (ng/L) }\end{array}$ & $\begin{array}{c}\text { Total } \\
\text { Kjeldahl } \\
\text { nitrogen } \\
\text { (mg/L) }\end{array}$ & $\begin{array}{c}\text { Total } \\
\text { mercury } \\
\text { (ng/L) }\end{array}$ & $\begin{array}{c}\text { Total } \\
\text { phosphorus } \\
\text { (mg/L) }\end{array}$ \\
\hline $05 / 05 / 2005$ & 111.1 & .006 & .004 & 1.74 & 2.16 & .50 & 1.99 & .036 \\
\hline $07 / 21 / 2005$ & 85.1 & .011 & .002 & .98 & --- & .69 & 2.92 & .085 \\
\hline $08 / 04 / 2005$ & 68.5 & .011 & .002 & .78 & 2.52 & .77 & 2.25 & .062 \\
\hline $08 / 25 / 2005$ & 51.9 & .005 & .006 & 1.08 & 1.82 & .59 & 1.57 & .056 \\
\hline $10 / 19 / 2005$ & 45.8 & .021 & .017 & 1.44 & 1.12 & .32 & 1.26 & .042 \\
\hline $11 / 03 / 2005$ & 57.7 & .006 & .026 & 1.63 & 1.34 & .31 & .96 & .054 \\
\hline $11 / 16 / 2005$ & 51.6 & .018 & .013 & 1.62 & 1.40 & .37 & 1.85 & .042 \\
\hline
\end{tabular}

${ }^{1}$ Flow estimated from the St. Joseph River at Niles, Michigan, streamgaging station (04101500).

Table 3-4. Concentration data for the Indiana Harbor and Ship Canal at East Chicago, Indiana (04092750).

$\left[\mathrm{m}^{3} / \mathrm{s}\right.$, cubic meters per second; $\mathrm{mg} / \mathrm{L}$, milligrams per liter; $\mathrm{ng} / \mathrm{L}$, nanograms per liter]

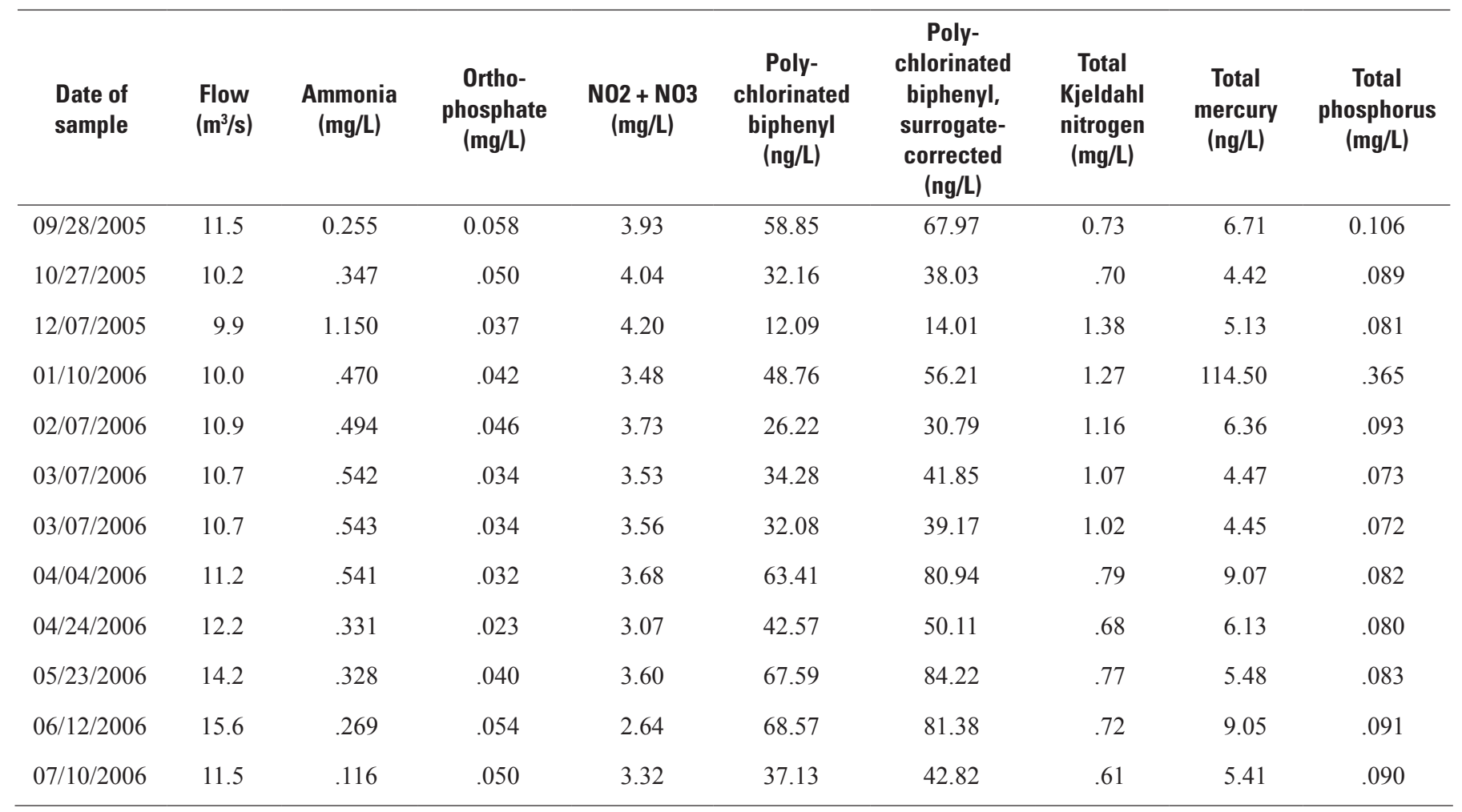


Table 3-5. Concentration data for the Lower Fox River at Oil Tank Depot at Green Bay, Wisconsin (040851385).

$\left[\mathrm{m}^{3} / \mathrm{s}\right.$, cubic meters per second; $\mathrm{mg} / \mathrm{L}$, milligrams per liter; $\mathrm{ng} / \mathrm{L}$, nanograms per liter; $<$, less than; MRL, U.S. Geological Survey Mercury Research Laboratory; SLH, Wisconsin State Laboratory of Hygiene; $\mu \mathrm{g} / \mathrm{L}$, micrograms per liter; ---, not determined]

\begin{tabular}{|c|c|c|c|c|c|c|c|c|}
\hline $\begin{array}{l}\text { Date of } \\
\text { sample }\end{array}$ & $\begin{array}{l}\text { Flow } \\
\left(\mathrm{m}^{3} / \mathrm{s}\right)\end{array}$ & $\begin{array}{c}\text { Ammonia } \\
\text { (mg/L) }\end{array}$ & $\begin{array}{c}\text { Ortho- } \\
\text { phosphate } \\
\text { (mg/L) }\end{array}$ & $\begin{array}{c}\mathrm{NO2}+\mathrm{NO3} \\
(\mathrm{mg} / \mathrm{L})\end{array}$ & $\begin{array}{c}\text { Poly- } \\
\text { chlorinated } \\
\text { biphenyl } \\
\text { (ng/L) }\end{array}$ & $\begin{array}{c}\text { Poly- } \\
\text { chlorinated } \\
\text { biphenyl, } \\
\text { surrogate- } \\
\text { corrected } \\
\text { (ng/L) }\end{array}$ & $\begin{array}{c}\text { Total } \\
\text { Kjeldahl } \\
\text { nitrogen } \\
\text { (mg/L) }\end{array}$ & $\begin{array}{c}\text { Total } \\
\text { phosphorus } \\
\text { (mg/L) }\end{array}$ \\
\hline $08 / 03 / 2005$ & 56.9 & $<0.015$ & 0.078 & $<0.019$ & 82.66 & 88.09 & 1.80 & 0.261 \\
\hline $09 / 15 / 2005$ & 59.5 & .017 & .090 & $<.019$ & 151.95 & 155.55 & 1.91 & .331 \\
\hline $09 / 15 / 2005$ & 59.5 & $<.015$ & .088 & $<.019$ & 148.59 & 155.33 & --- & .325 \\
\hline $10 / 19 / 2005$ & 74.8 & .159 & .079 & .42 & 124.01 & 133.45 & 1.71 & .252 \\
\hline $11 / 08 / 2005$ & 85.5 & .199 & .064 & .34 & 51.95 & 56.71 & 1.00 & .280 \\
\hline $01 / 10 / 2006$ & 160.3 & .165 & .049 & .57 & 4.52 & 5.33 & .85 & .087 \\
\hline $03 / 22 / 2006$ & 130.3 & .048 & .011 & .54 & 16.37 & 20.18 & .85 & .063 \\
\hline $04 / 25 / 2006$ & 120.1 & .186 & .020 & .91 & 75.80 & 94.70 & .98 & .120 \\
\hline $05 / 17 / 2006$ & 325.6 & .120 & .042 & 1.46 & 40.64 & 44.43 & 1.25 & .118 \\
\hline $06 / 21 / 2006$ & 32.0 & .144 & .038 & .48 & 44.61 & 60.17 & 1.23 & .147 \\
\hline 07/06/2006 & 39.4 & .072 & .041 & .02 & 66.85 & 76.87 & 1.57 & .188 \\
\hline $07 / 26 / 2006$ & 51.0 & .099 & .030 & .12 & 88.45 & 88.38 & 1.92 & .192 \\
\hline 08/09/2006 & 28.6 & $<.015$ & .053 & $<.019$ & 91.66 & 90.15 & 1.62 & .209 \\
\hline
\end{tabular}


Table 3-5. Concentration data for the Lower Fox River at Oil Tank Depot at Green Bay, Wisconsin (040851385). —Continued

$\left[\mathrm{m}^{3} / \mathrm{s}\right.$, cubic meters per second; mg/L, milligrams per liter; ng/L, nanograms per liter; <, less than; MRL, U.S. Geological Survey Mercury Research Laboratory; SLH, Wisconsin State Laboratory of Hygiene; $\mu \mathrm{g} / \mathrm{L}$, micrograms per liter; ---, not determined]

\begin{tabular}{|c|c|c|c|c|c|c|c|c|c|}
\hline $\begin{array}{l}\text { Date of } \\
\text { sample }\end{array}$ & $\begin{array}{l}\text { Flow } \\
\left(\mathrm{m}^{3} / \mathrm{s}\right)\end{array}$ & $\begin{array}{c}\text { Total } \\
\text { mercury, } \\
\text { MRL, } \\
\text { (ng/L) }\end{array}$ & $\begin{array}{c}\text { Total } \\
\text { mercury, } \\
\text { SLH, } \\
\text { (ng/L) }\end{array}$ & $\begin{array}{c}\text { Dissolved } \\
\text { methyl- } \\
\text { mercury } \\
\text { (ng/L) }\end{array}$ & $\begin{array}{c}\text { Total } \\
\text { methyl- } \\
\text { mercury } \\
\text { (ng/L) }\end{array}$ & $\begin{array}{c}\text { Total } \\
\text { suspended } \\
\text { solids } \\
\text { (mg/L) }\end{array}$ & $\begin{array}{c}\text { Total } \\
\text { organic } \\
\text { carbon } \\
\text { (mg/L) }\end{array}$ & $\begin{array}{c}\text { Dissolved } \\
\text { organic } \\
\text { carbon } \\
\text { (mg/L) }\end{array}$ & $\begin{array}{c}\text { Chlorophyll-a } \\
(\mu \mathrm{g} / \mathrm{L})\end{array}$ \\
\hline $08 / 03 / 2005$ & 56.9 & 30.06 & 37.30 & 0.04 & 0.328 & 56 & 11.0 & 7.3 & 92.5 \\
\hline $09 / 15 / 2005$ & 59.5 & 48.08 & 52.82 & .04 & .338 & 85 & 11.0 & 7.9 & 105 \\
\hline $09 / 15 / 2005$ & 59.5 & 48.59 & 51.97 & .04 & .379 & --- & 10.0 & 8.2 & 106 \\
\hline $10 / 19 / 2005$ & 74.8 & 54.02 & 58.56 & .04 & .333 & 55 & 8.4 & 7.9 & $* 46.1$ \\
\hline $11 / 08 / 2005$ & 85.5 & 18.44 & 19.26 & .04 & .109 & 28 & 7.4 & 7.7 & 11.9 \\
\hline $01 / 10 / 2006$ & 160.3 & 4.47 & 5.57 & .04 & .014 & 6 & 8.4 & 7.8 & 2 \\
\hline $03 / 22 / 2006$ & 130.3 & 2.60 & 3.92 & .04 & .028 & 9 & 8.3 & 7.6 & 12 \\
\hline $04 / 25 / 2006$ & 120.1 & 28.10 & 30.85 & .06 & .230 & 43 & 8.5 & 6.8 & $* 20.9$ \\
\hline $05 / 17 / 2006$ & 325.6 & 19.52 & 21.80 & .07 & .164 & 36 & 7.4 & 7.0 & 10.8 \\
\hline $06 / 21 / 2006$ & 32.0 & 13.34 & 12.21 & .05 & .140 & 25 & 9.0 & 7.8 & 38 \\
\hline $07 / 06 / 2006$ & 39.4 & 22.92 & 24.85 & .04 & .228 & 39 & 7.9 & 7.9 & 67.1 \\
\hline $07 / 26 / 2006$ & 51.0 & 18.00 & 21.64 & .07 & .213 & 33 & 9.5 & 9.5 & 79.4 \\
\hline 08/09/2006 & 28.6 & 19.38 & 18.65 & .06 & .203 & 43 & 9.9 & 10.0 & 109 \\
\hline
\end{tabular}

"Laboratory interference. 
This page is intentionally blank. 


\section{Appendix 4. Concentrations of Ammonia Nitrogen and Total Kjeldahl Nitrogen at Five \\ Lake Michigan Tributary Monitoring Sites}



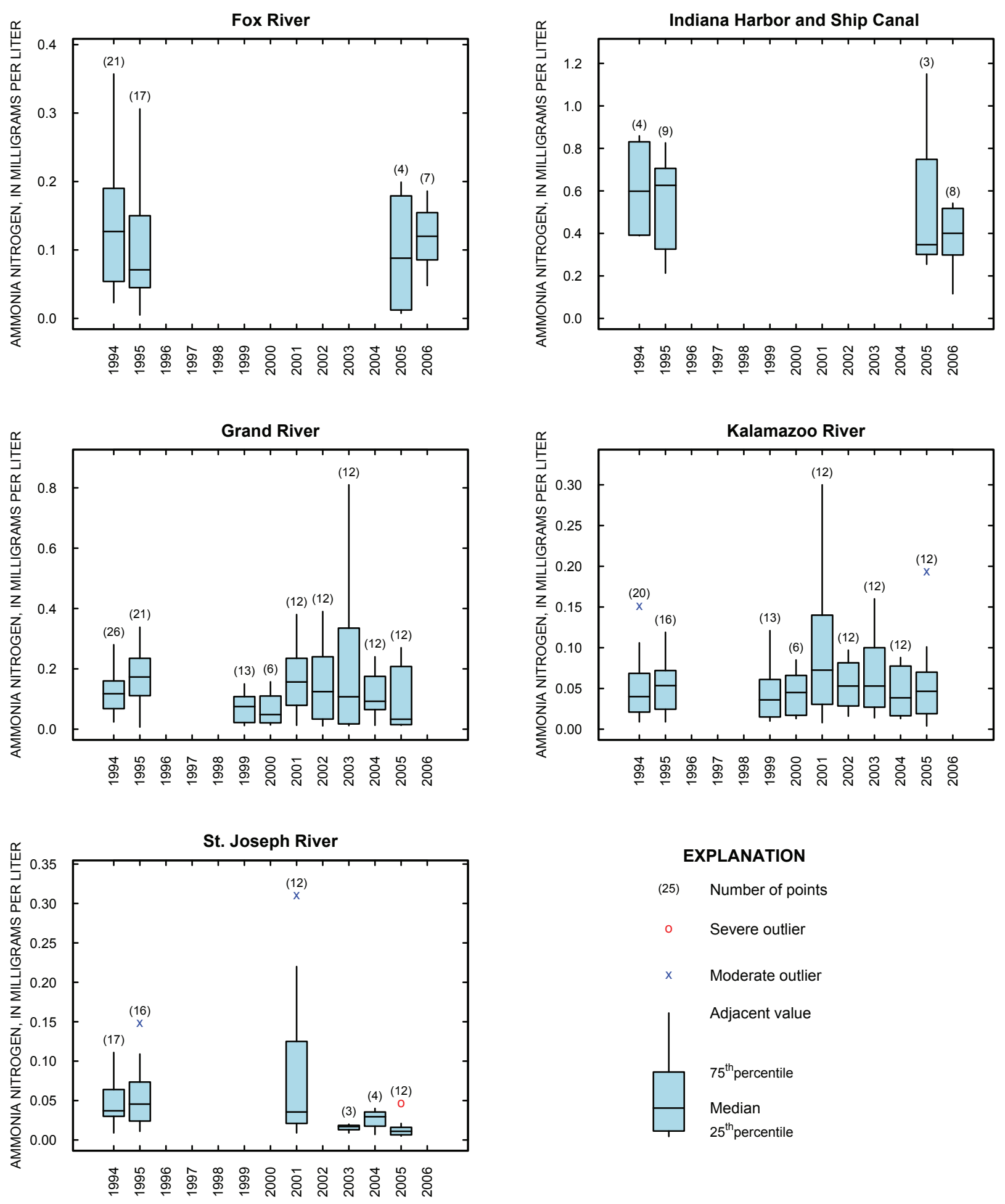

Figure 4-1. Concentrations of ammonia nitrogen at five Lake Michigan tributary monitoring sites, 1994-2006. 

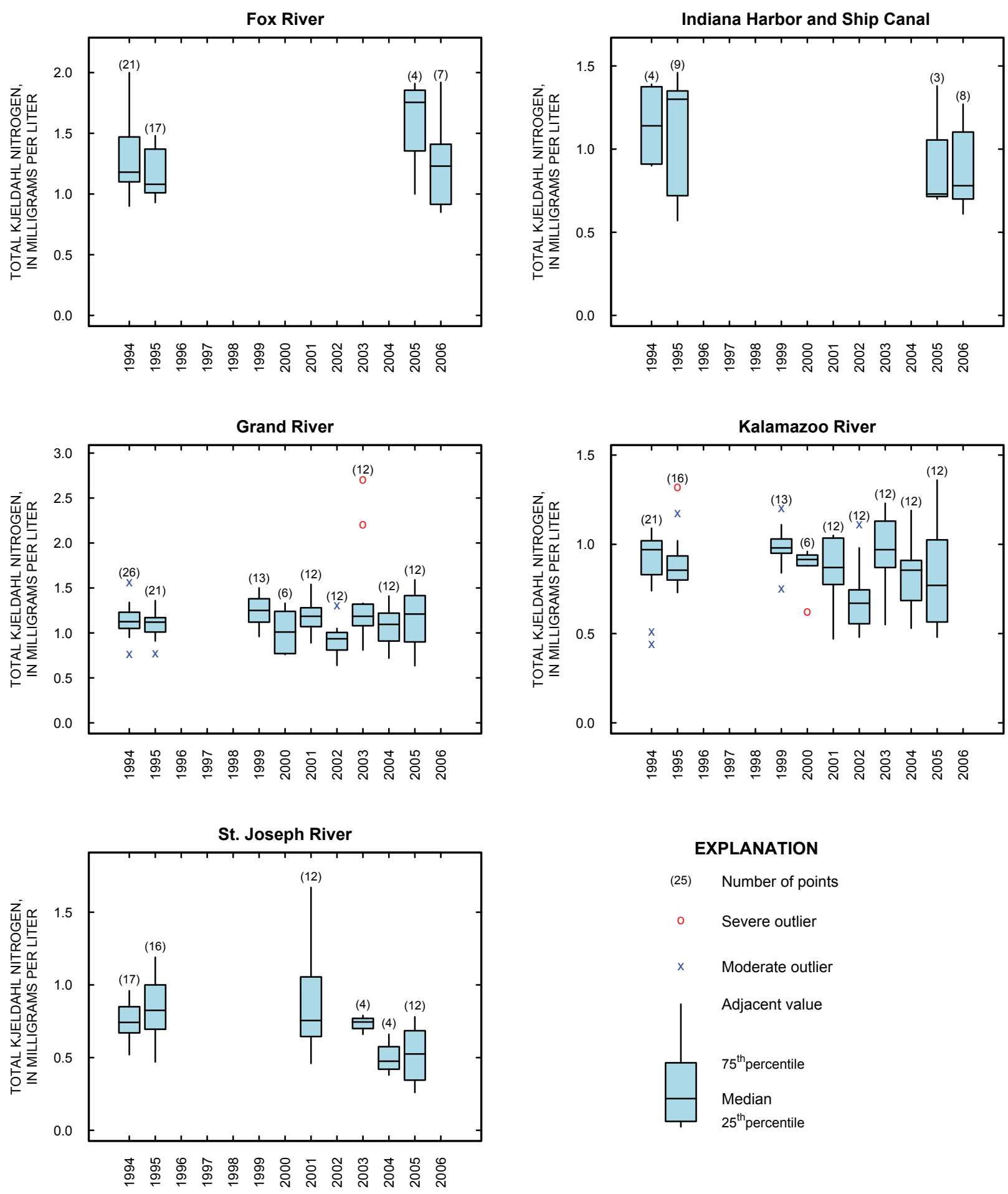

Figure 4-2. Concentrations of total Kjeldahl nitrogen at five Lake Michigan tributary monitoring sites, 1994-2006. 
This page is intentionally blank. 
Appendix 5. Calculated Loads 


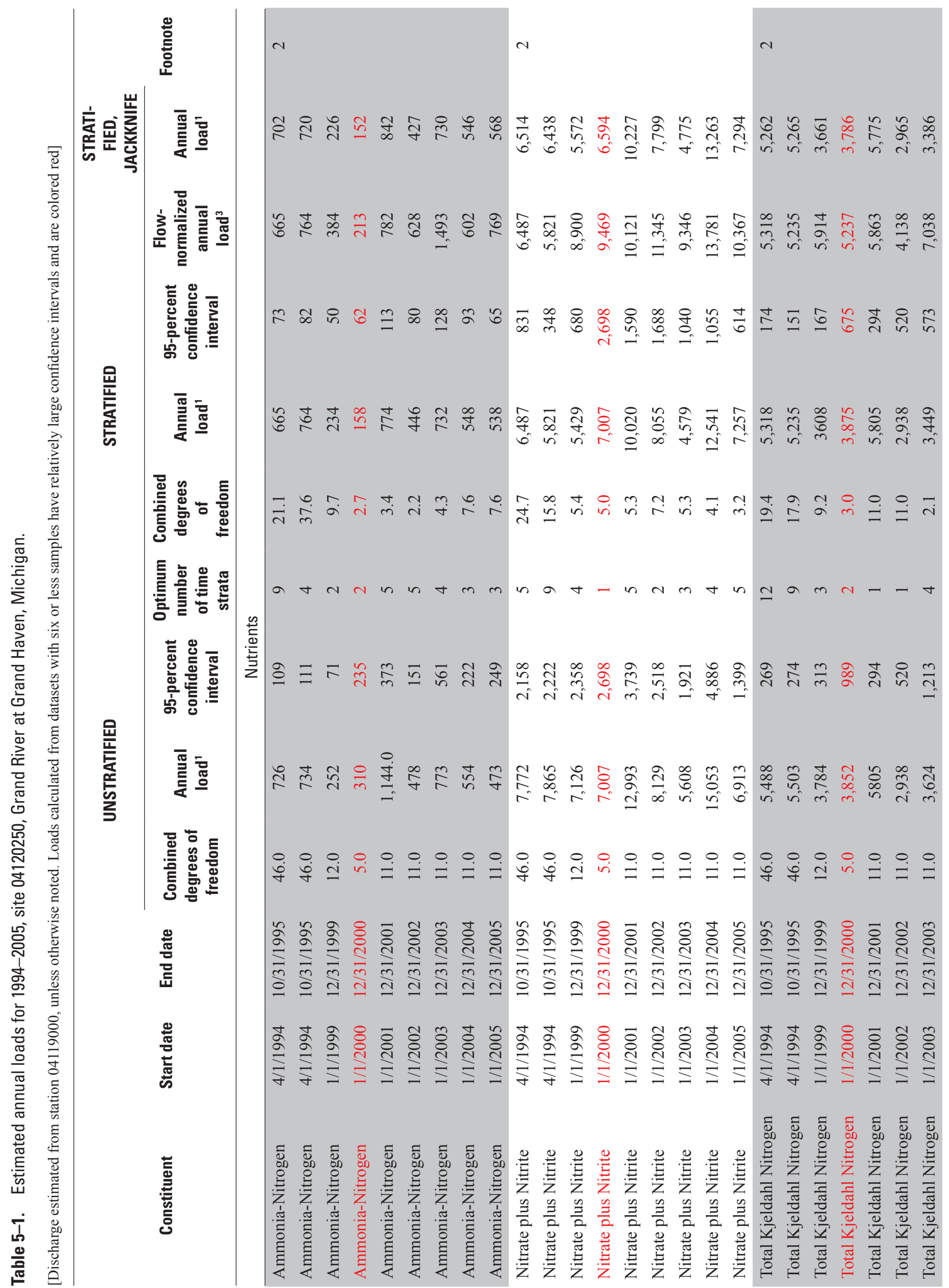




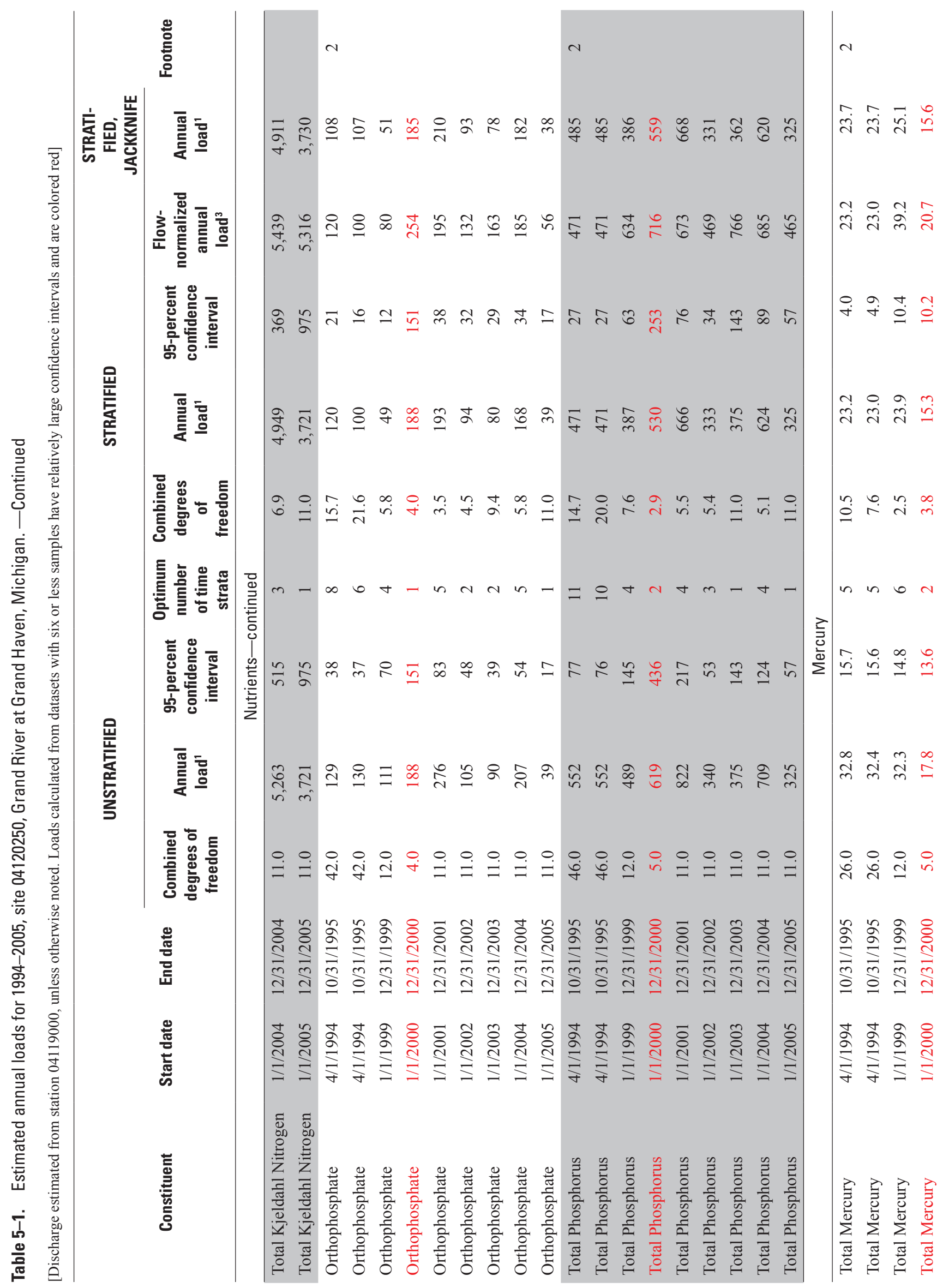




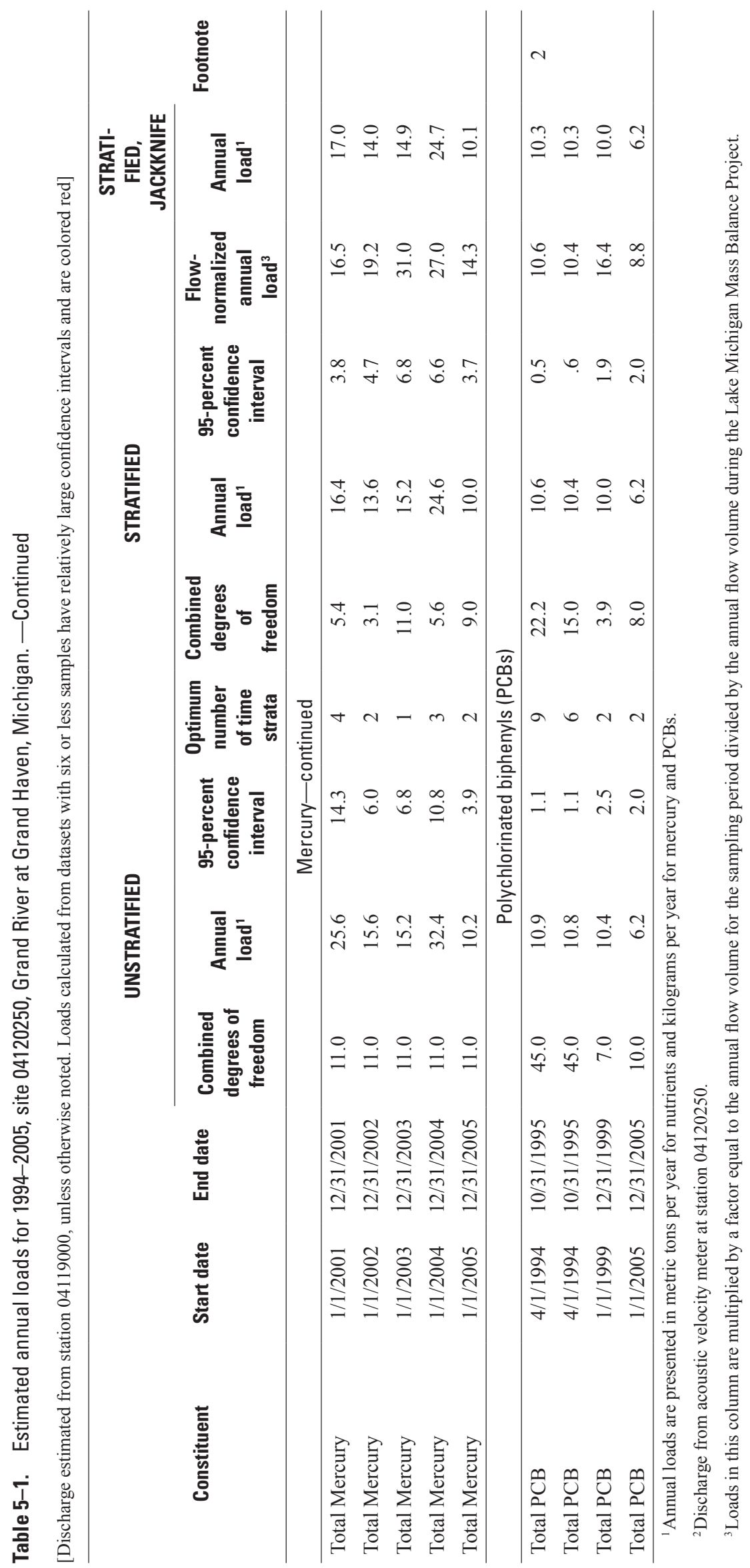




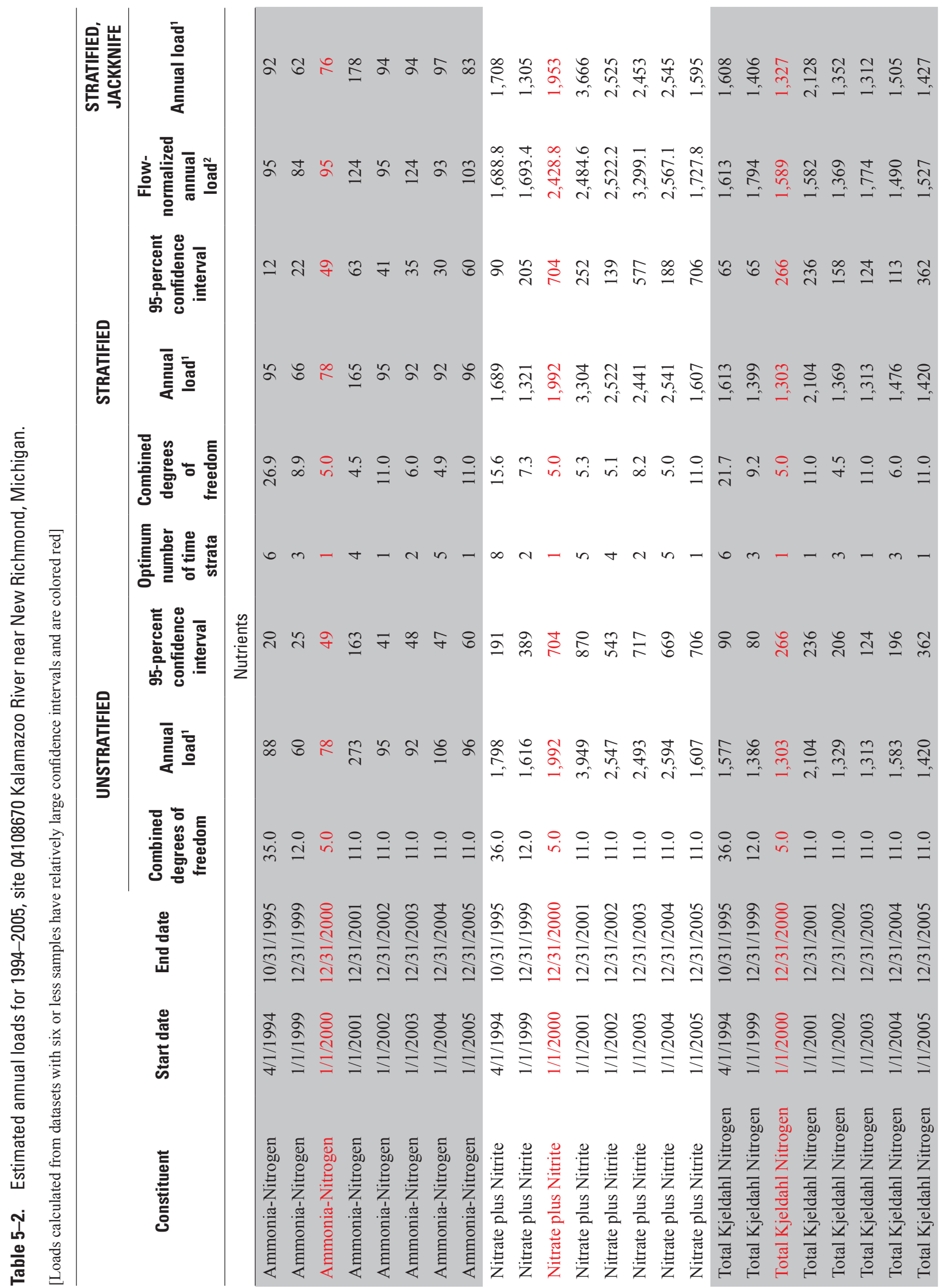




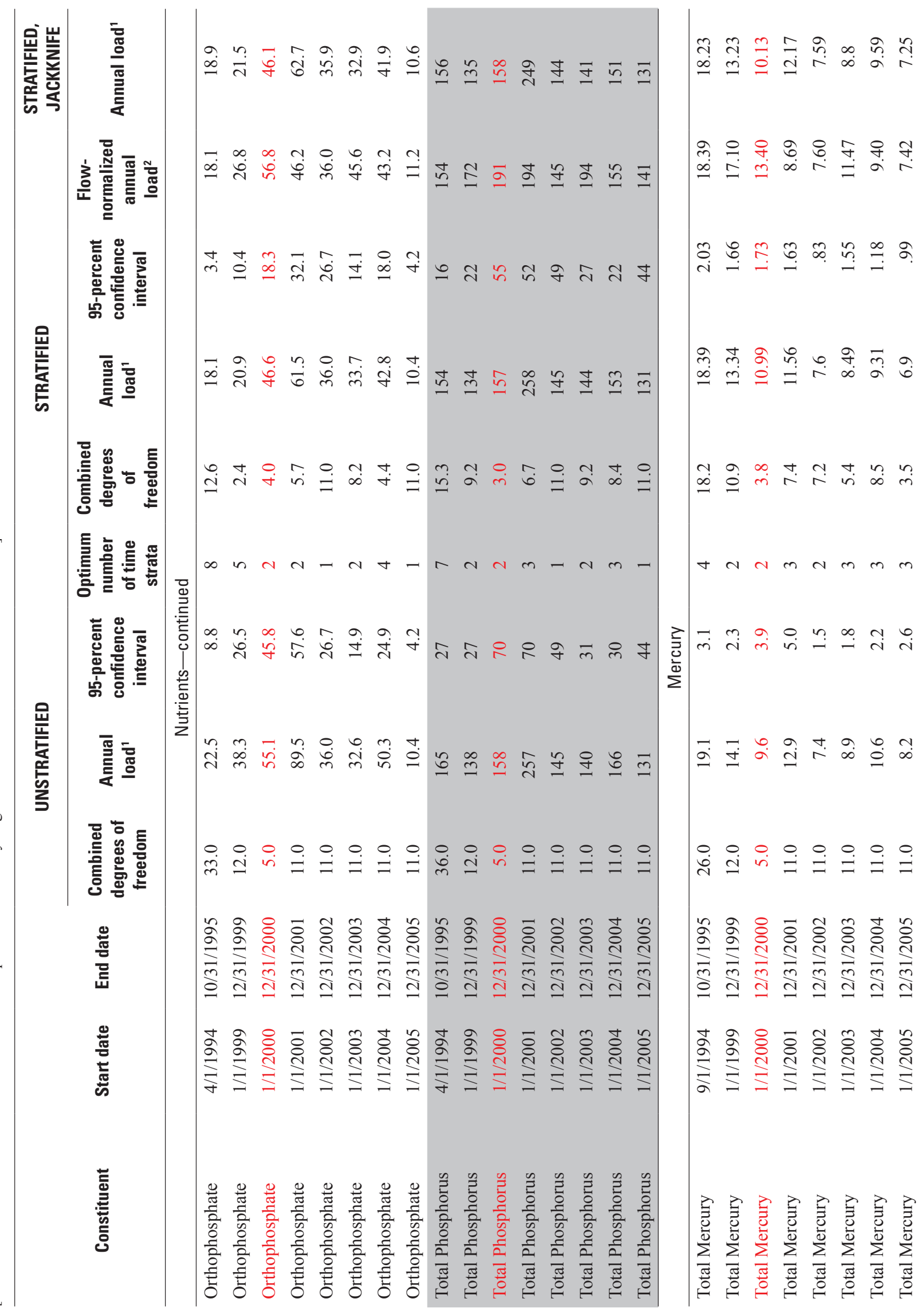




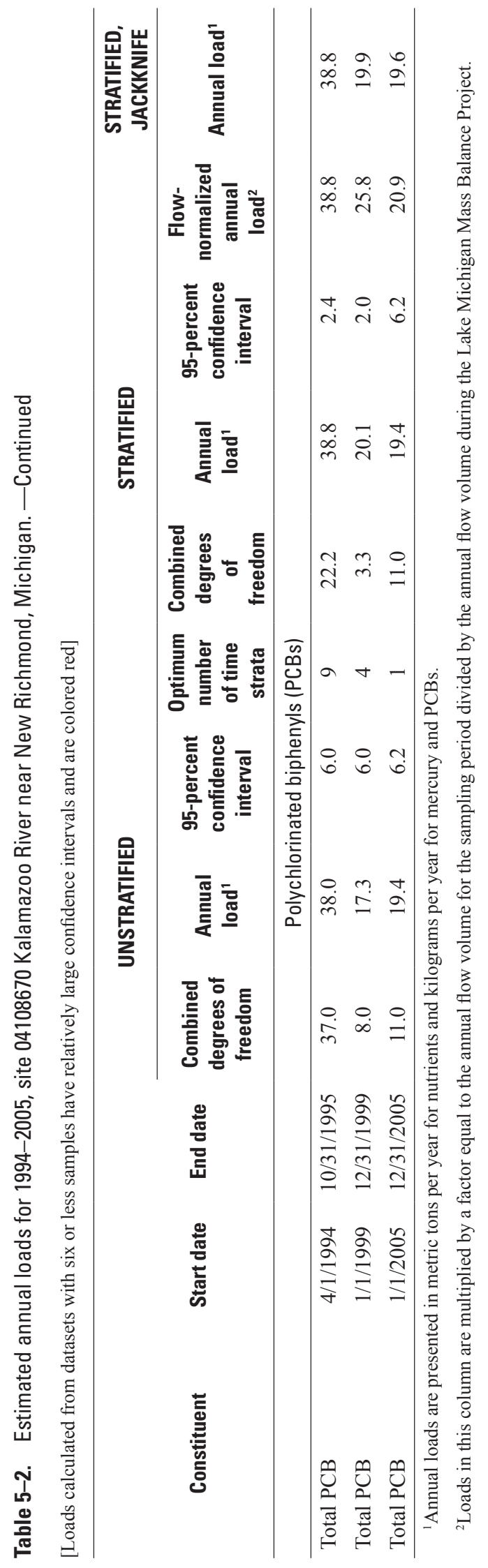




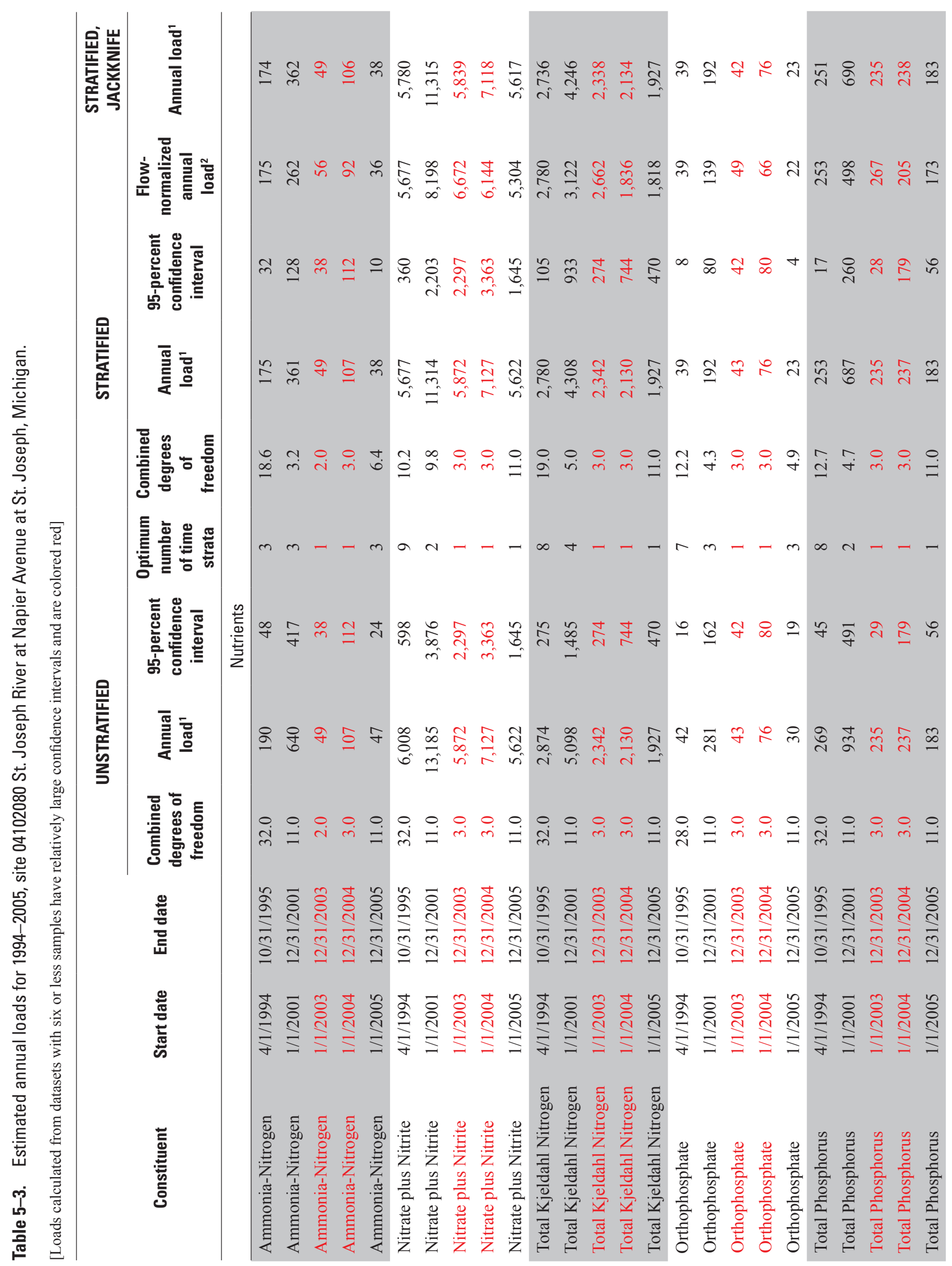




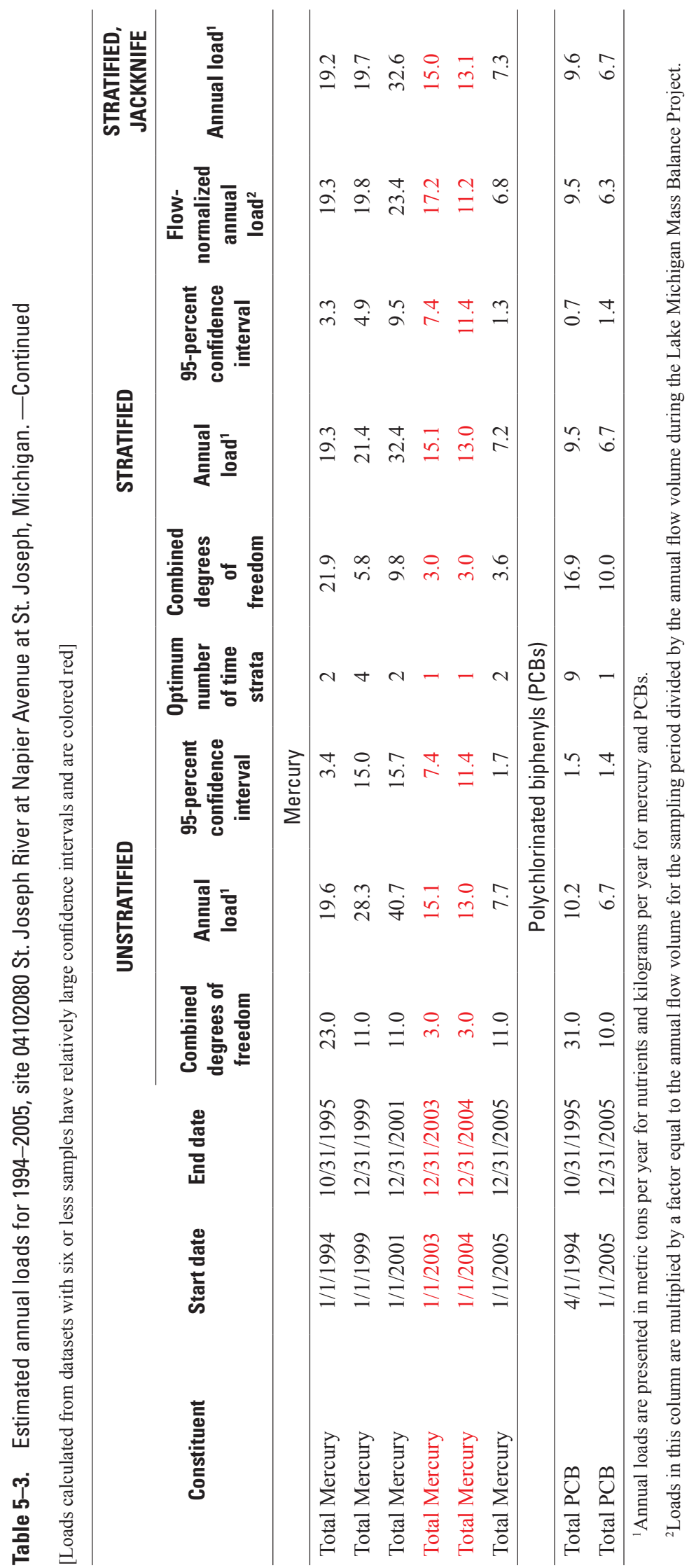




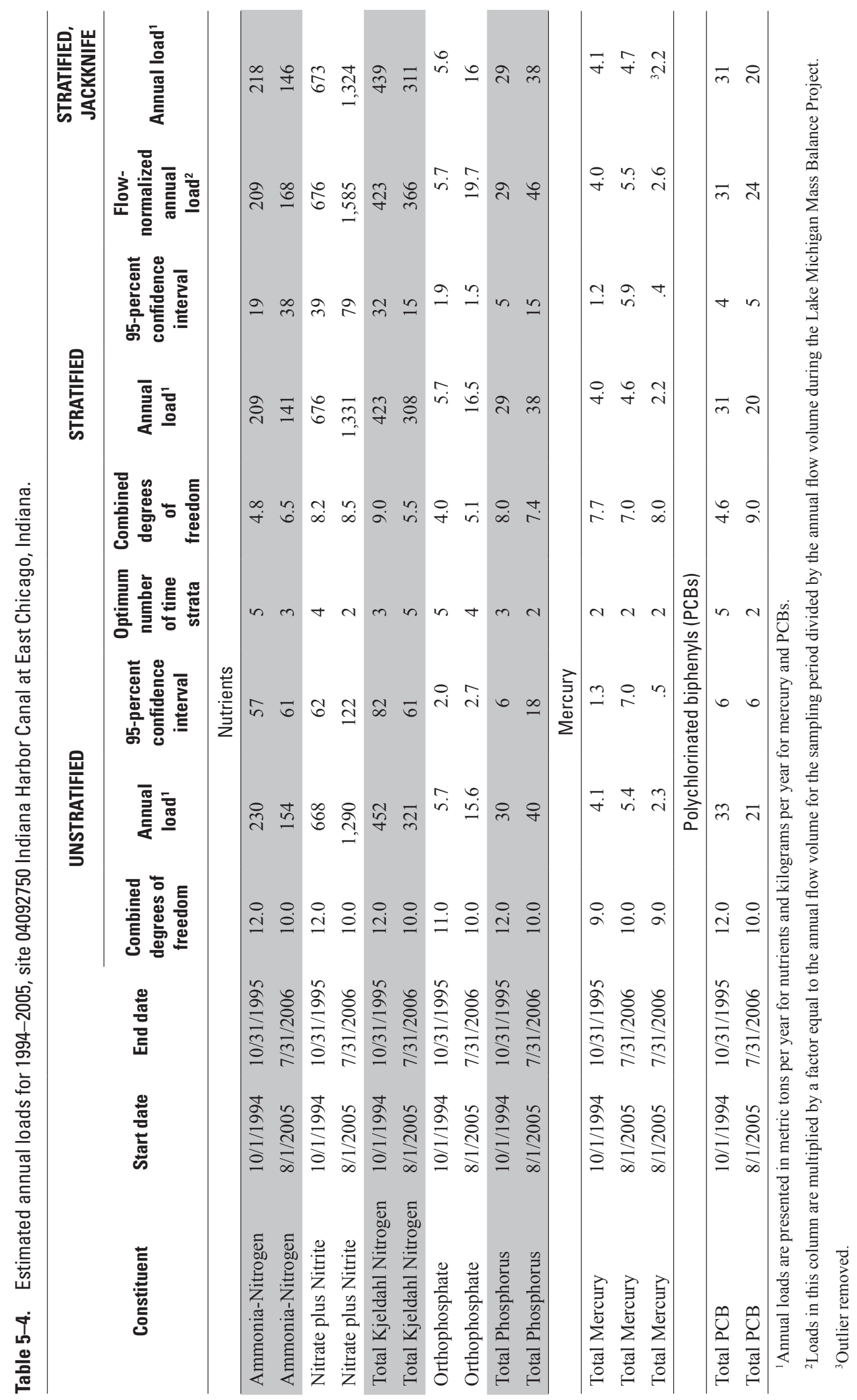




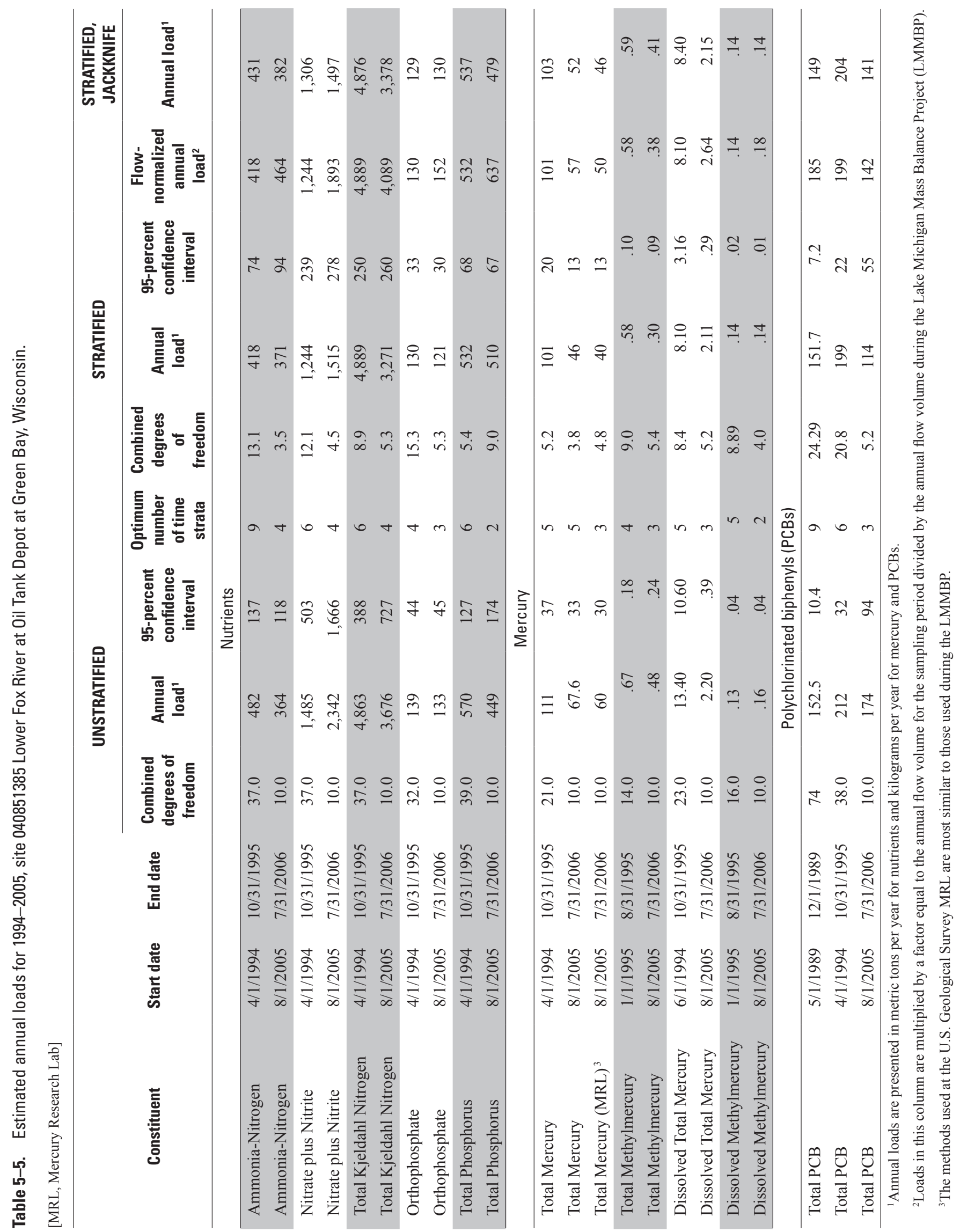


This page is intentionally blank. 


\section{Appendix 6. Description of Beale Load Calculation and Jackknifing Procedure}

Many techniques have been used to calculate loads on the basis of observed discharge and concentration. These techniques include direct numerical integration, workedrecord interpretation, regression analysis, and ratio estimation (Richards, 1998).

For this work, the AutoBeale source code (Richards, 1999) was modified in two ways in order to allow jackknifing estimates to be made. First, the code was modified to allow a genetic algorithm routine to optimize the number and arrangement of stratification boundaries. The genetic algorithm replaced a complicated rules-based stratification selection routine. Second, a jackknifing control module was added to the code to generate the jackknife estimate of load.

The genetic algorithm code PIKAIA was incorporated into AutoBeale; PIKAIA is a public-domain code developed at the National Center for Atmospheric Research's High Altitude Observatory (Charbonneau and Knapp, 1995; Charbonneau, 2002). PIKAIA belongs to a class of methods aimed at numerical optimization known as genetic algorithm-based optimizers.

A function was written to provide PIKAIA with a "fitness function"; this function in turn was related to the sum of mean-squared error calculated by AutoBeale. PIKAIA seeks to maximize the fitness function, whereas for this work the intent was to minimize the sum of mean-squared error. Therefore, the fitness function was defined as 1 over the calculated sum of mean-squared error times a scaling factor. As the root mean-squared error decreased, the fitness function increased, providing a measure of the optimization progress to PIKAIA.

PIKAIA finds optimum strata boundaries by performing the following steps:

1. Generate an initial "population" of solutions; each member of the population is defined by a "genome," an integer value that can be converted to a series of real values between 0 and 1 .

2. Generate strata boundaries. The real values (between 0 and 1) correspond to the boundary location relative to the starting and ending Julian day.

3. Evaluate the fitness of each member of the population by running AutoBeale with the current set of strata boundaries.

4. Eliminate one or more of the members of the population with the lowest fitness scores.

5. Replace the eliminated population members with new, randomly generated members via reproduction between the population members with the highest fitness scores. Each parent's genome is split, and two fragments are pasted together to form a new genome, which is inserted into the population. Random mutations in the genome are allowed to occur in a small fraction of new genomes.

6. Repeat steps 2 through 5 above for all members of the population over hundreds of generations.

At the end of the optimization process, a single individual with the best fitness score is selected, and the strata boundaries are evaluated and reported.

Various combinations of genetic algorithm parameters were tested with AutoBeale. The results reported here were obtained by running the combined PIKAIA/AutoBeale code with a population of 150 , for a maximum of 700 generations. For the datasets described in this report, the mean square of residual error generally increased for strata numbers exceeding about 8; therefore, the combined PIKAIA/AutoBeale code was limited to examining stratification schemes with 15 or fewer strata in them.

The AutoBeale program provides an estimate of uncertainty (95-percent confidence interval) for load estimates on the basis of the sum of the mean-squared error over all strata; generally, the stronger the relation between flow and load within a given strata, the lower the mean-squared error and the associated confidence interval. However, this method for estimating the confidence interval is dependent on the specifics of the timing and number of samples collected. In order to include possible effects involving the structure of the sampling program, a jackknifing module was added to the AutoBeale program.

The jackknife "plug-in" estimate of the load is calculated as follows (Efron and Tibshirani, 1993):

$$
\hat{\theta}_{(.)}=\frac{1}{n} \sum_{i=1}^{n} \hat{\theta}_{(i)}
$$

where

$$
\begin{aligned}
& \hat{\theta}_{i} \quad \text { is the load as calculated when the } i^{\text {th }} \\
& \text { concentration data point has been } \\
& \text { excluded, and }
\end{aligned}
$$ $n \quad$ is the number of concentration data points; $\hat{\theta}_{(.)} \quad$ is effectively the mean of the loads calculated in this manner.

The estimate of standard error associated with the load estimate may be made as follows (Efron and Tibshirani, 1993):

$$
s e_{j a c k}=\sqrt{\frac{n-1}{n} \sum\left(\hat{\theta}_{(i)}-\hat{\theta}_{(.)}\right)^{2}}
$$


An estimate of the confidence interval associated with the load estimate may be made by means of the t-distribution:

$$
C I=\hat{\theta} \pm t_{n-1}^{(1-\alpha)} s e_{j a c k}
$$

where

$\alpha \quad=0.05$ if one is interested in estimating a 95-percent confidence interval.
As noted by Efron and Tibshirani (1993), the use of the $\mathrm{t}$-distribution in the calculation of the confidence intervals does not take into account any skewness in the underlying population, nor does it account for any other errors that can occur when $\theta$ is not the sample mean. 


\section{Appendix 7. Regression Model Details}

This section contains details regarding linear regression model construction. In addition, this section provides a summary of key model diagnostics, including the effect size as defined in the text and the variance inflation factors.

\section{Polychlorinated Biphenyl}

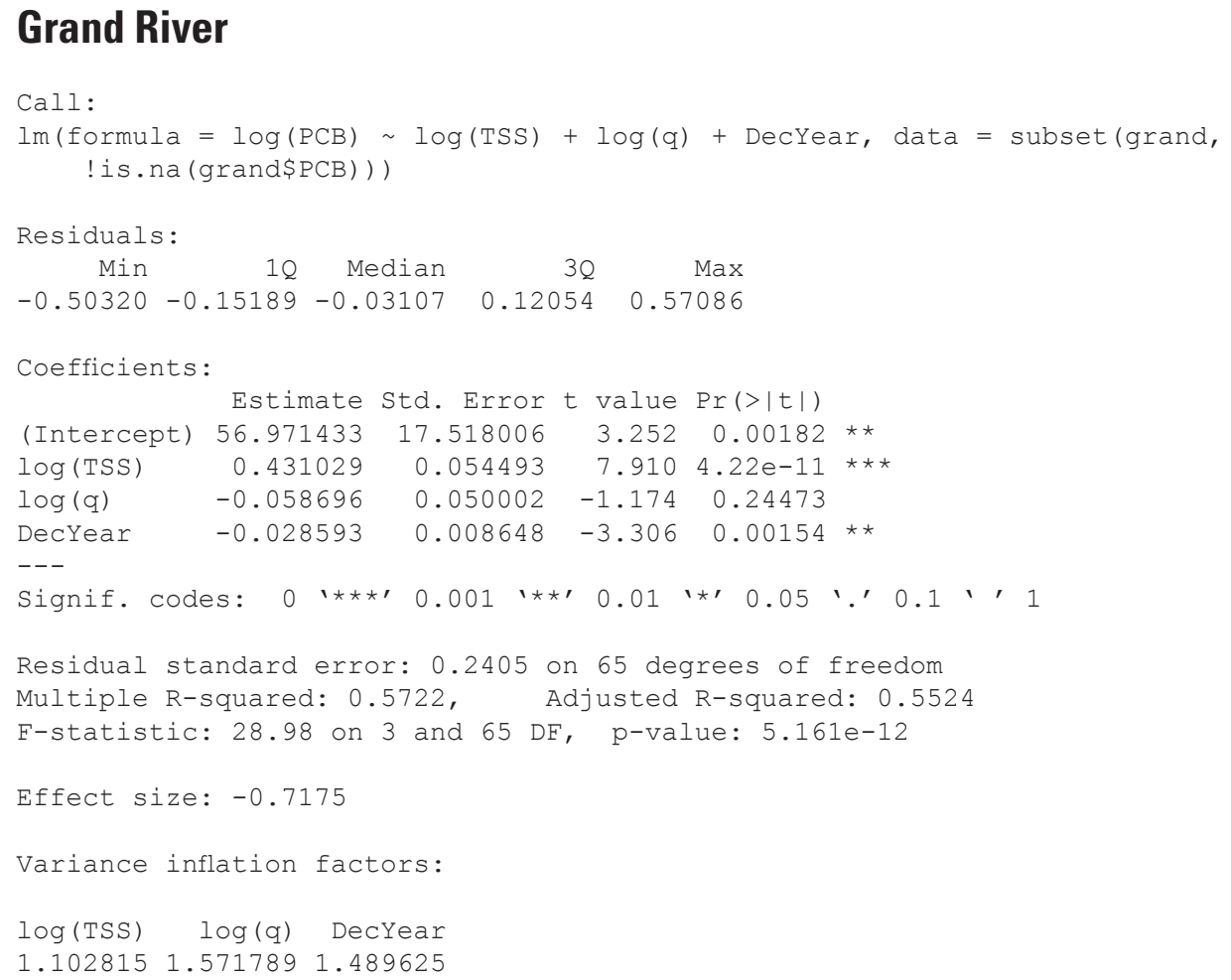

\section{Kalamazoo River}

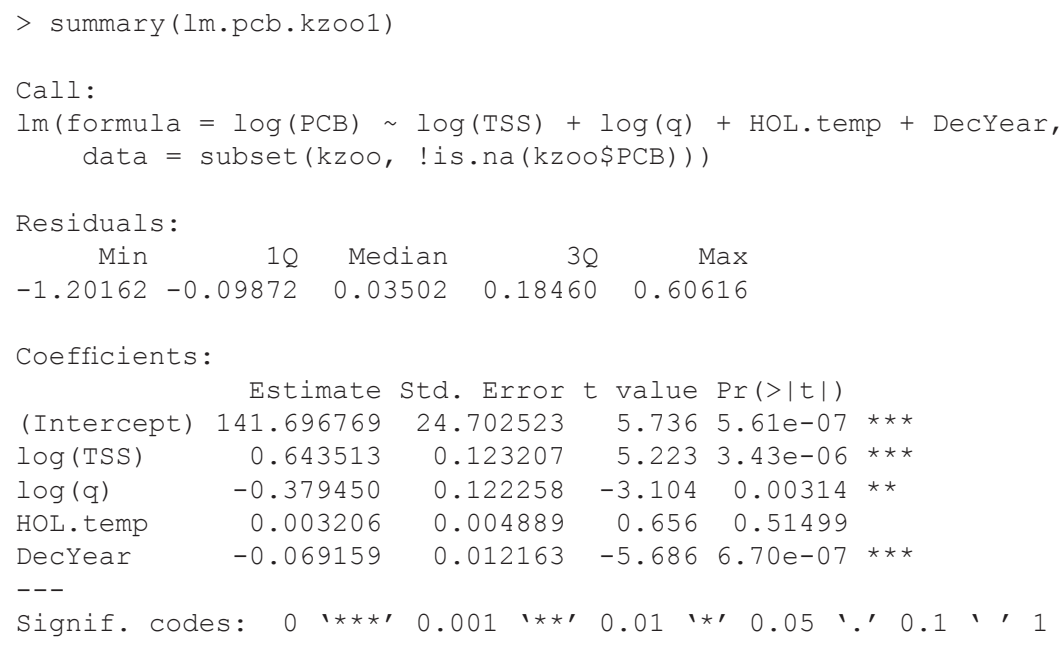


Residual standard error: 0.326 on 50 degrees of freedom

( 8 observations deleted due to missingness)

Multiple R-squared: 0.6833, Adjusted R-squared: 0.658

F-statistic: 26.97 on 4 and 50 DF, p-value: $5.918 e-12$

Effect size: -0.9880

Variance inflation factors:

$\log (\mathrm{TSS}) \quad \log (\mathrm{q})$ HOL.temp DecYear

$\begin{array}{llll}1.931384 & 1.436364 & 2.189684 & 1.445048\end{array}$

\section{St. Joseph River}

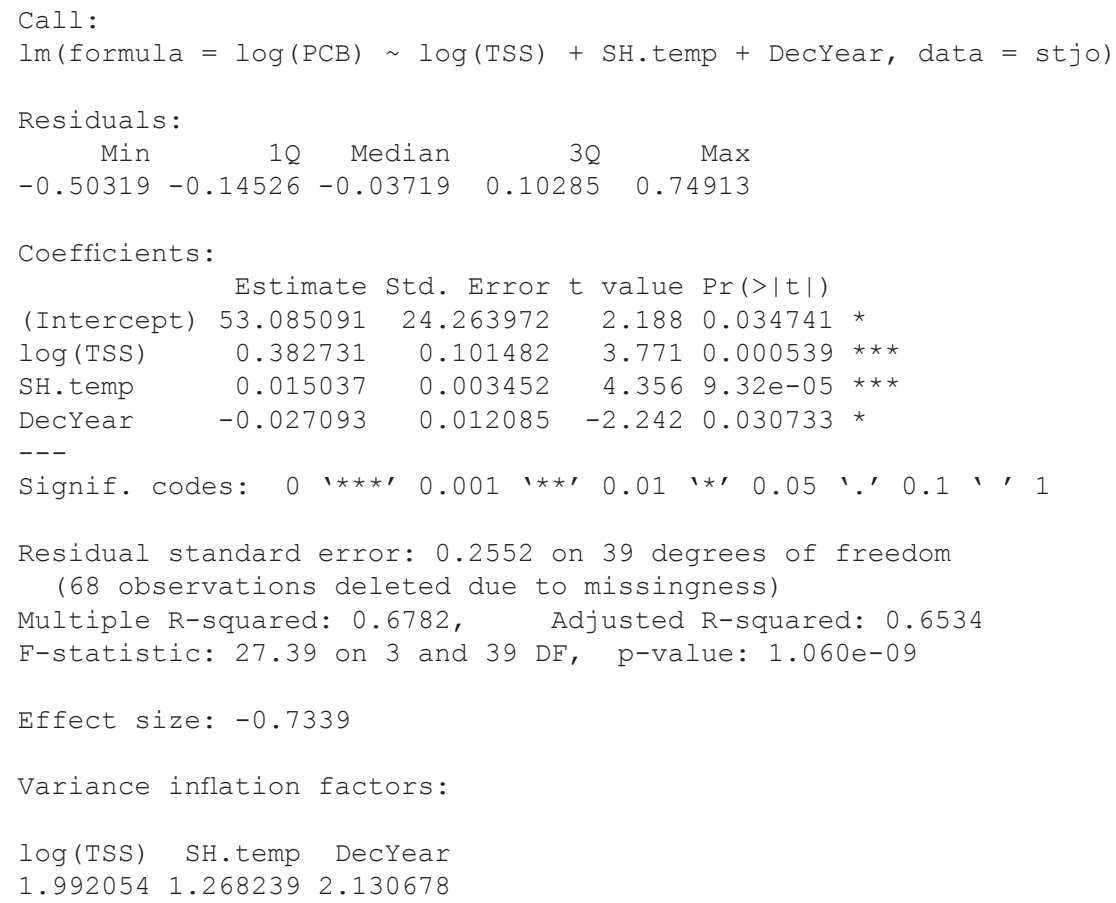

\section{Indiana Harbor and Ship Canal}

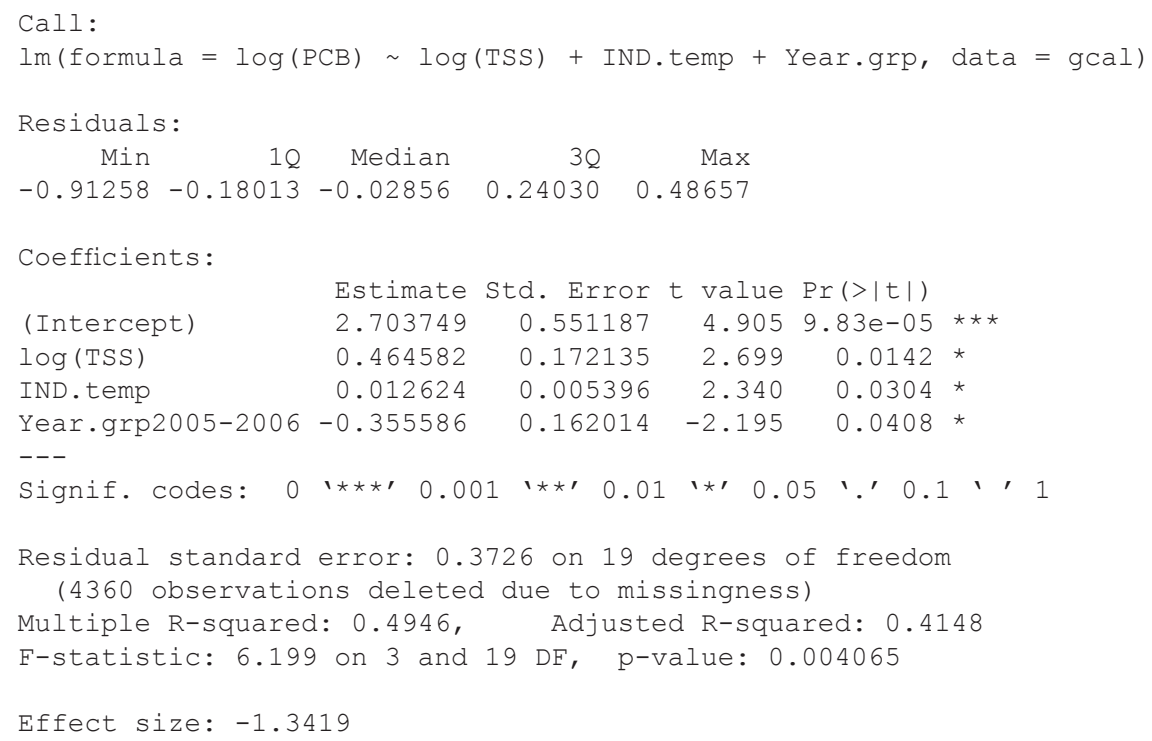


Variance inflation factors:

log (TSS) IND.temp Year.grp

1.2695971 .1832161 .084841

\section{Fox River}

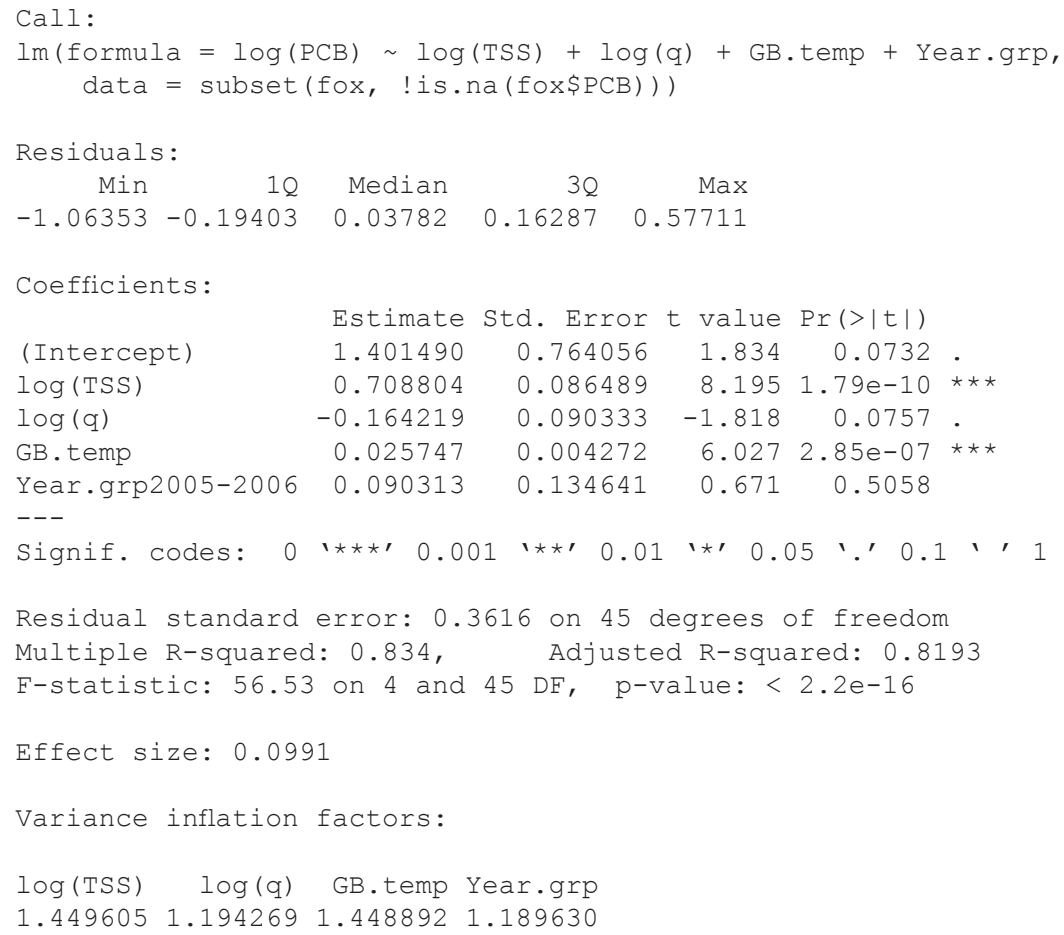




\section{Total Mercury}

\section{Grand River}

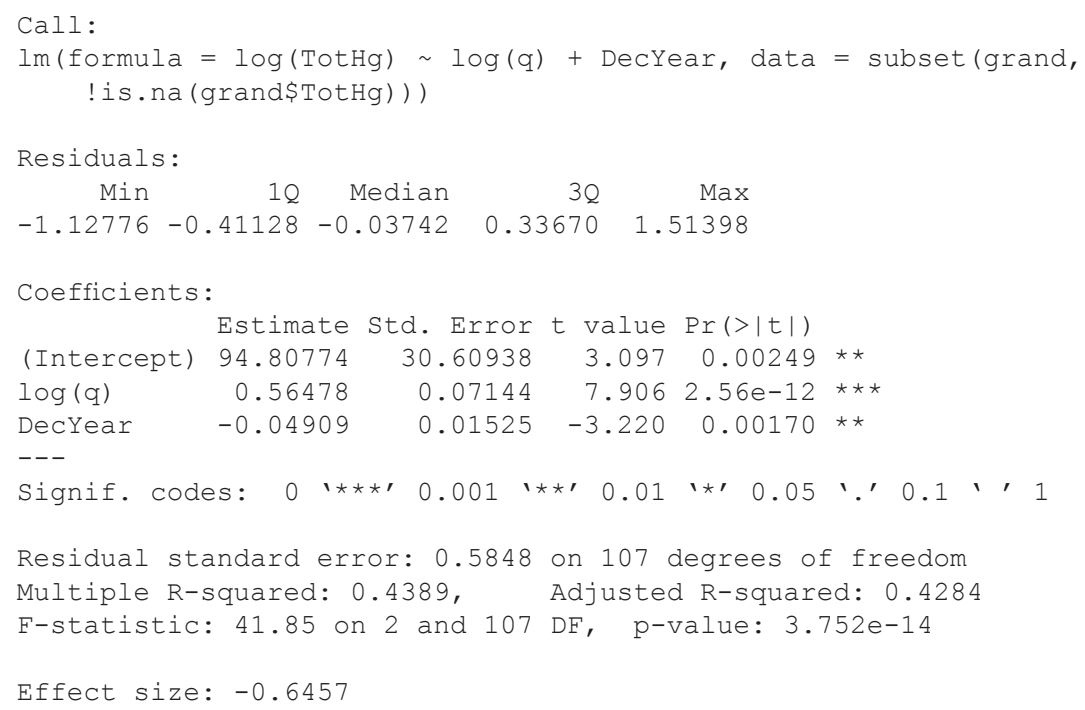

\section{Kalamazoo River}

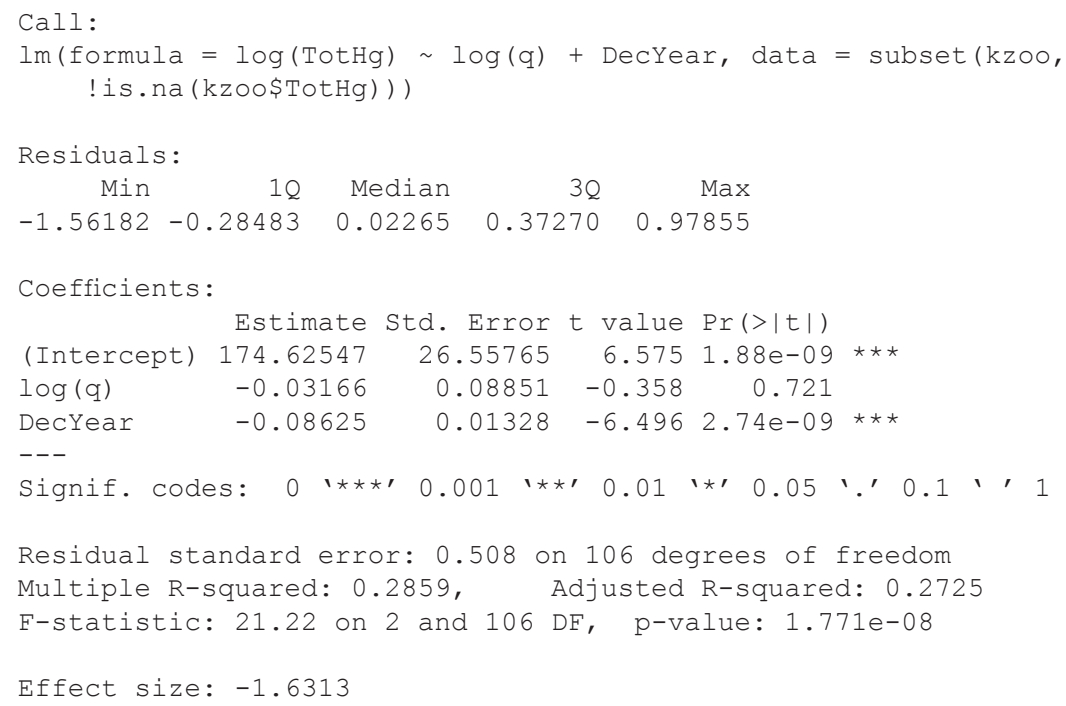

\section{St. Joseph River}

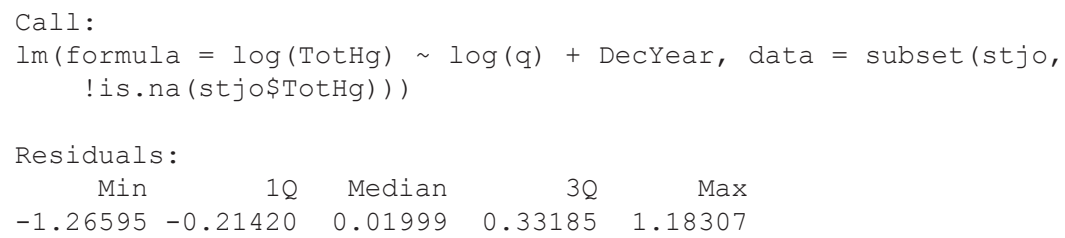




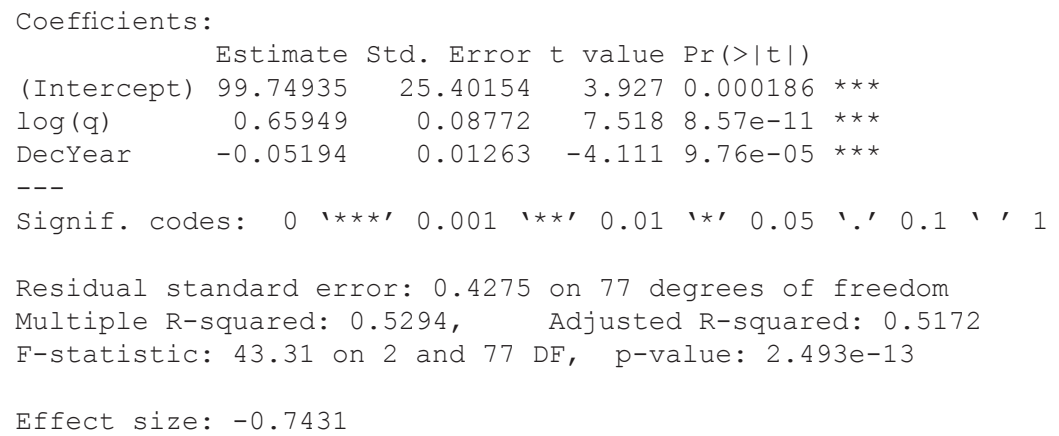

\section{Indiana Harbor and Ship Canal}

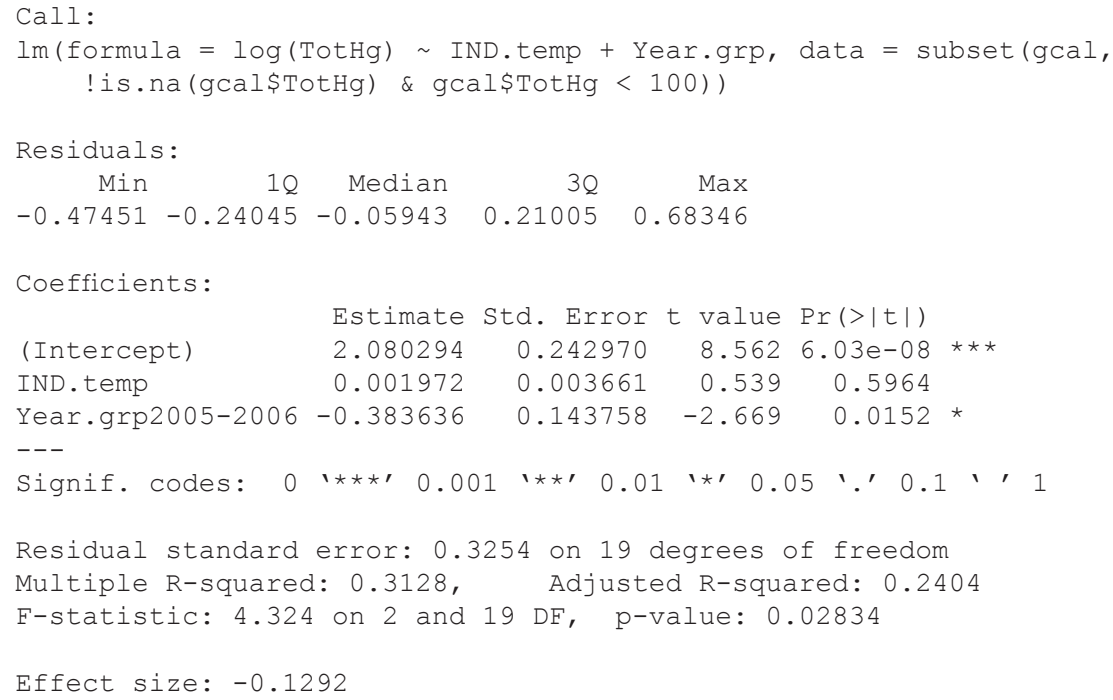

\section{Fox River}

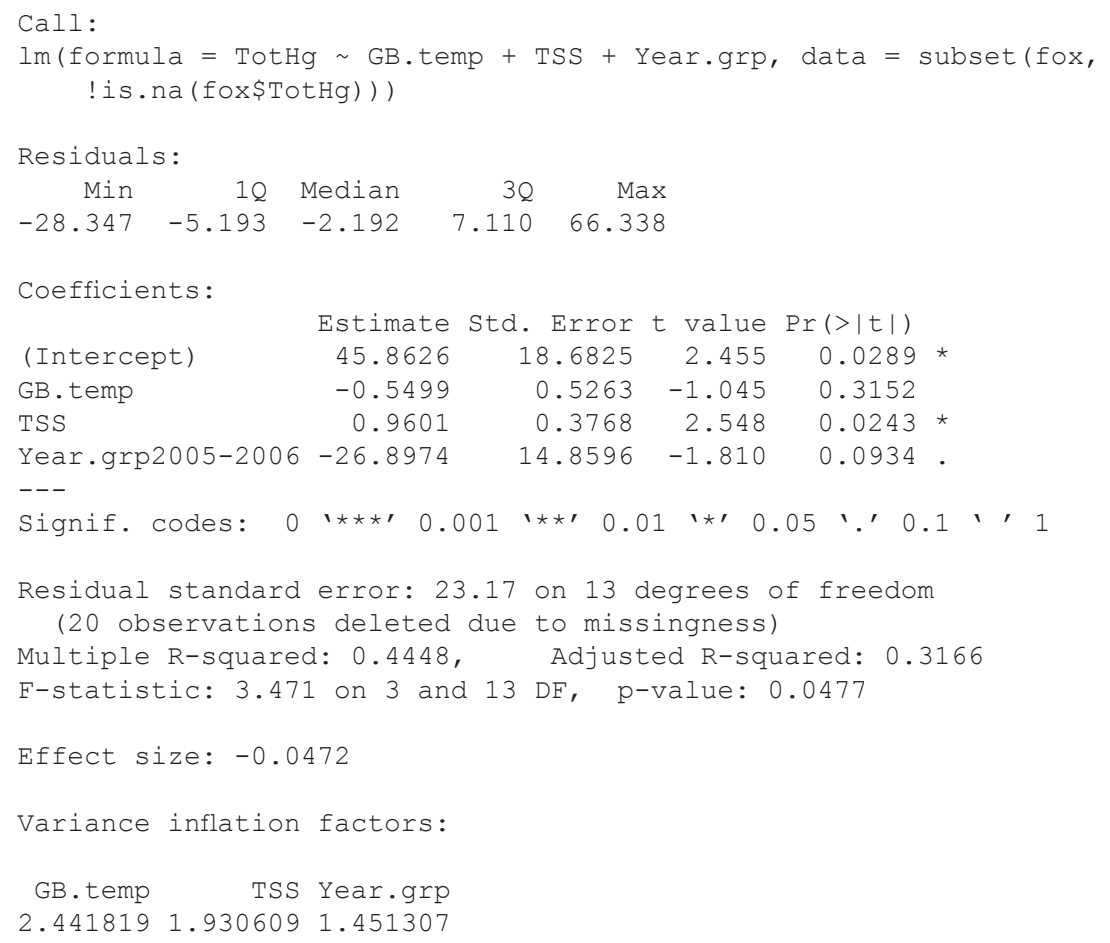




\section{Total Phosphorus}

\section{Kalamazoo River}

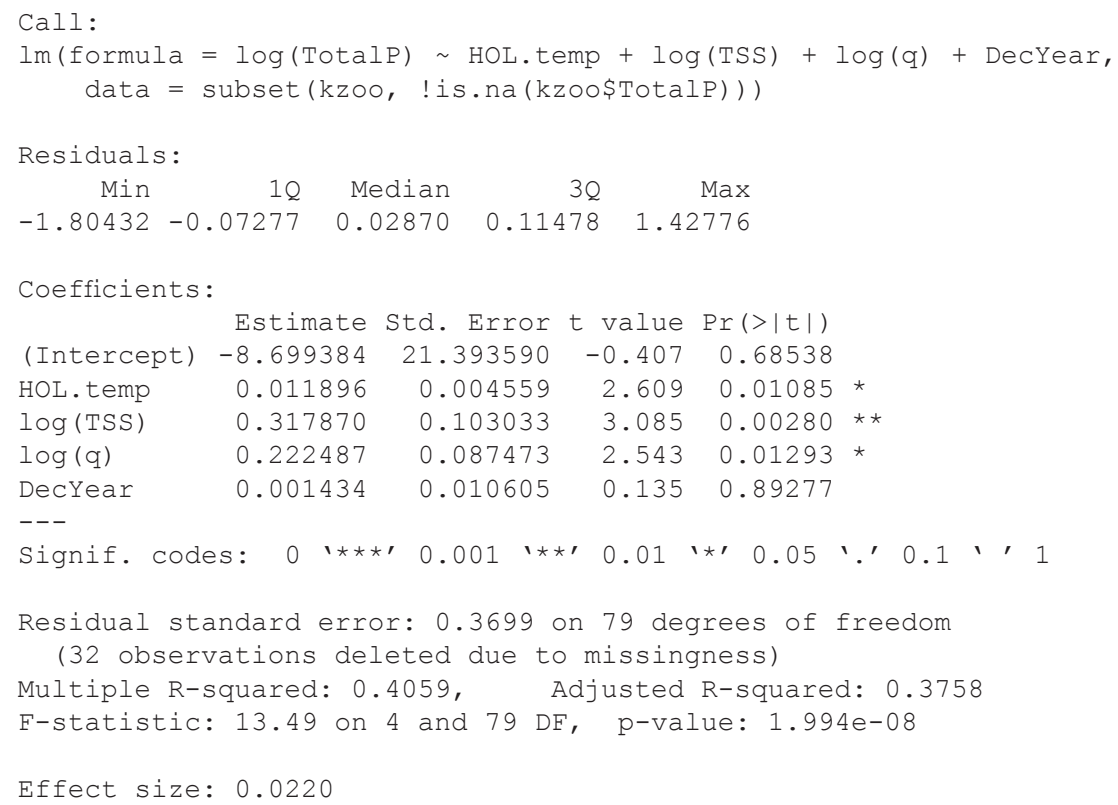




\section{St. Joseph River}

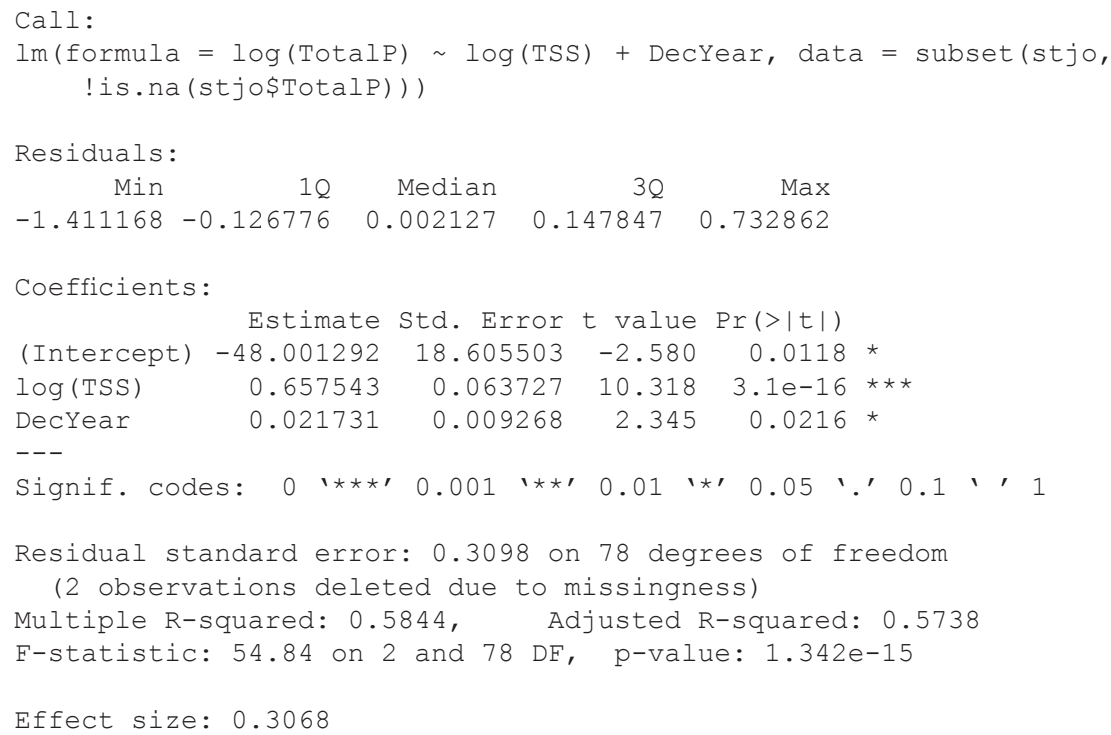

\section{Indiana Harbor and Ship Canal}

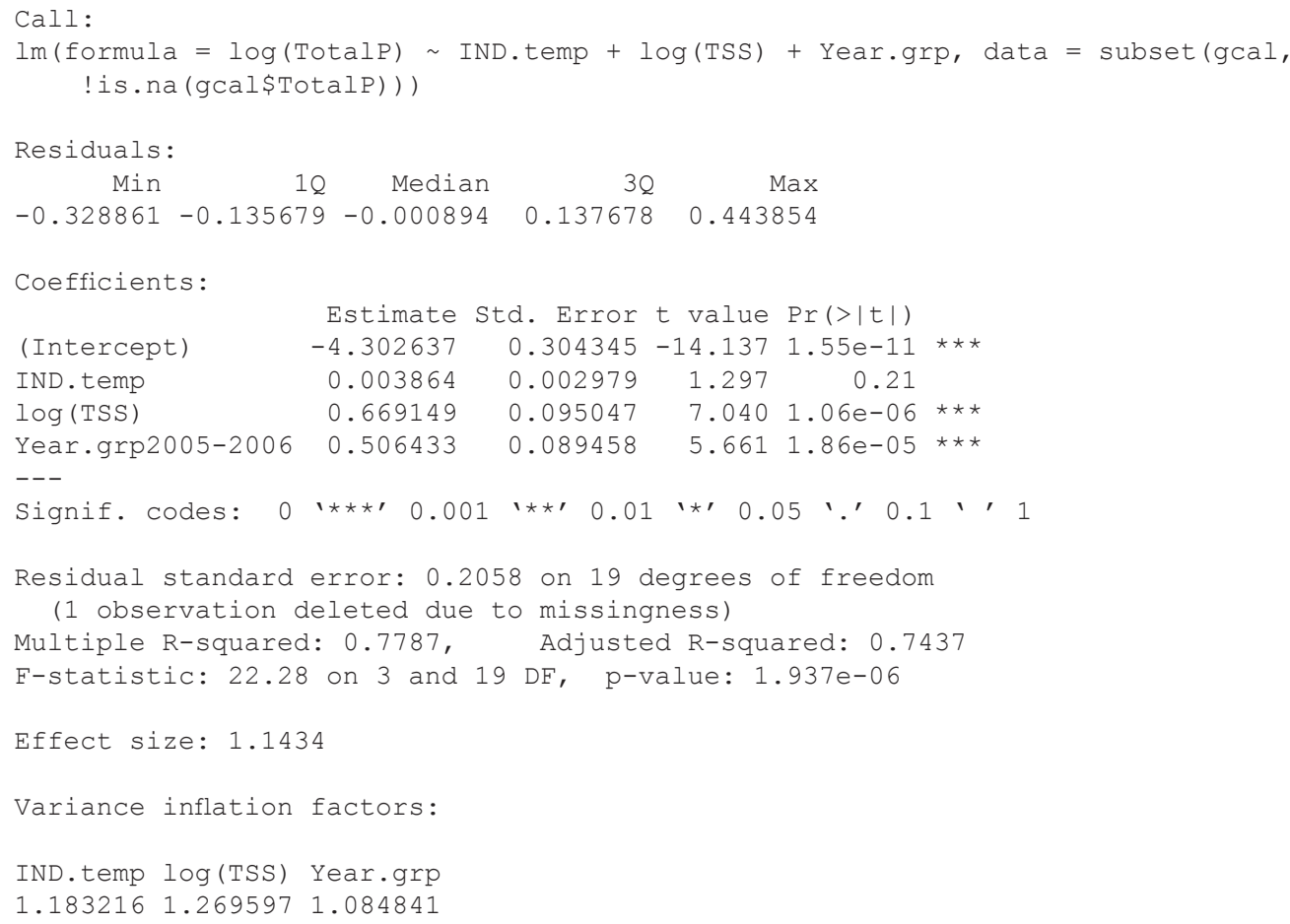




\section{Fox River}

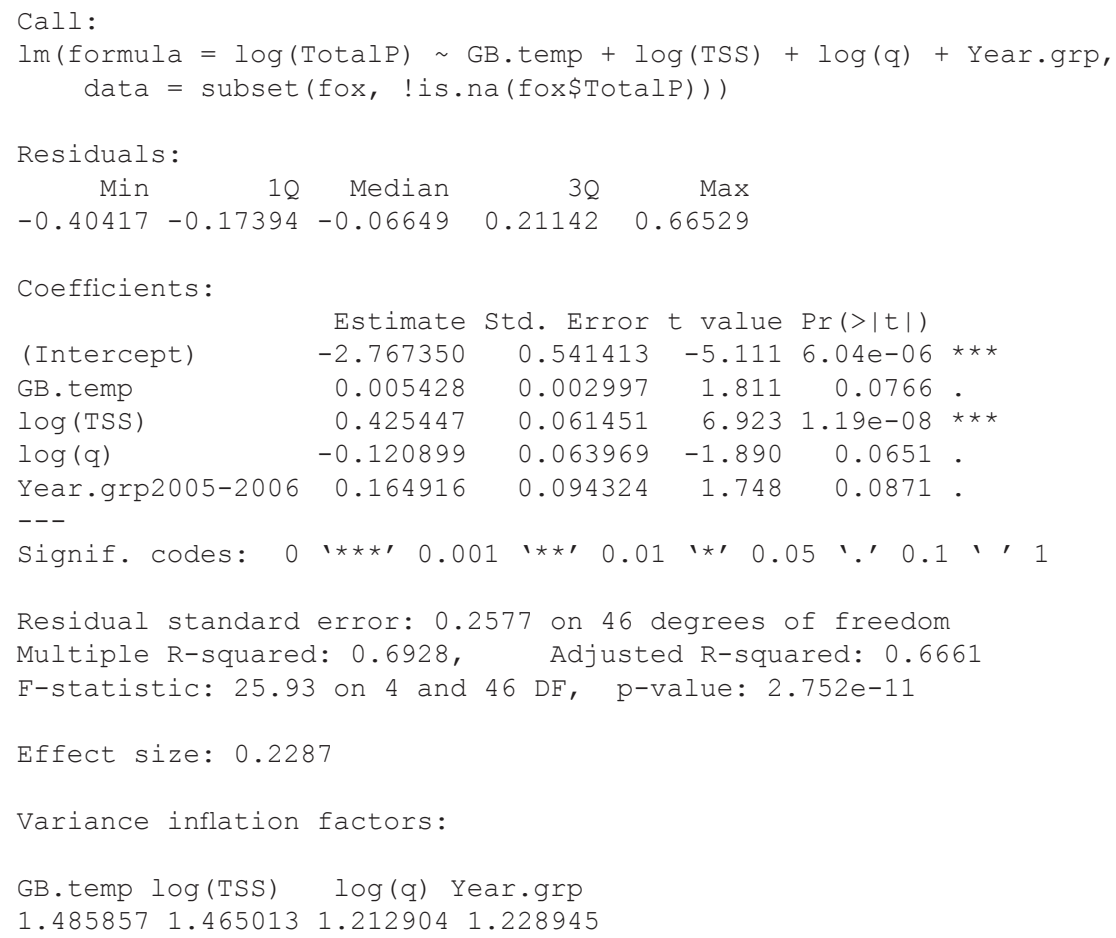




\section{Orthophosphate}

\section{Kalamazoo River}

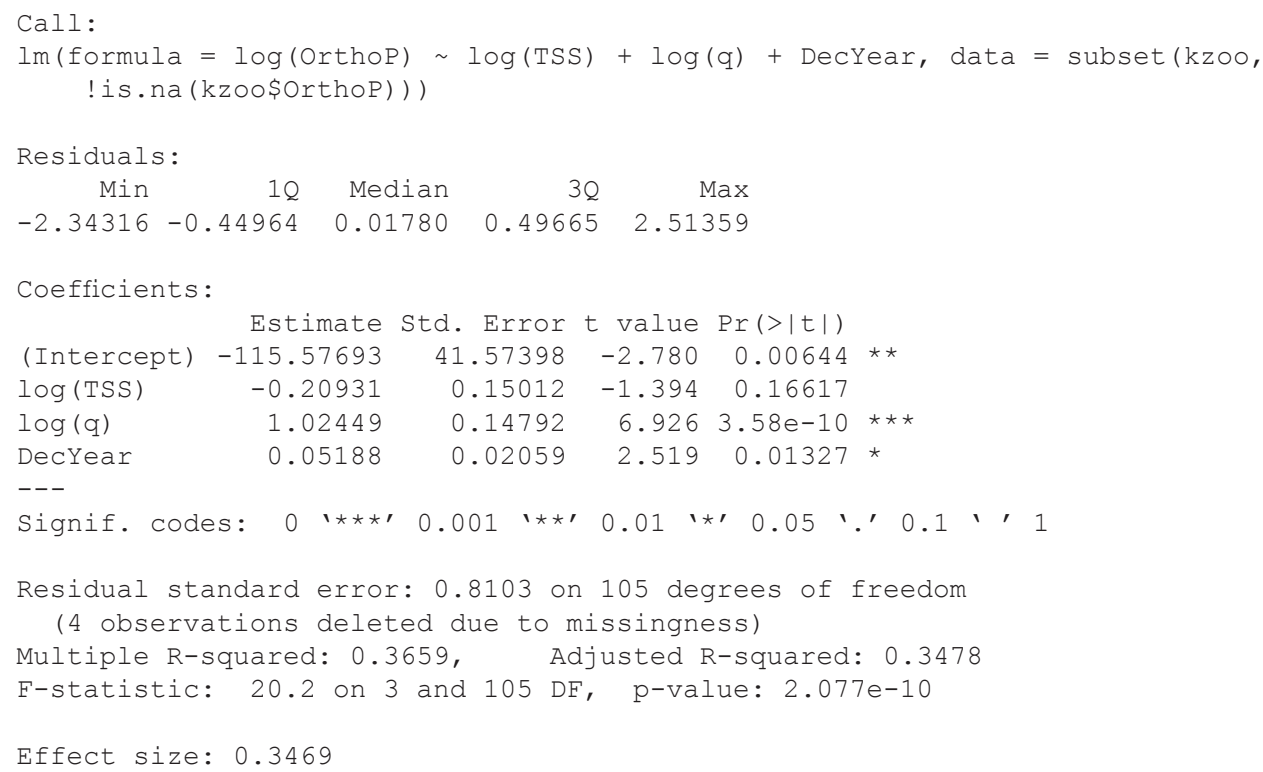

\section{St. Joseph River}

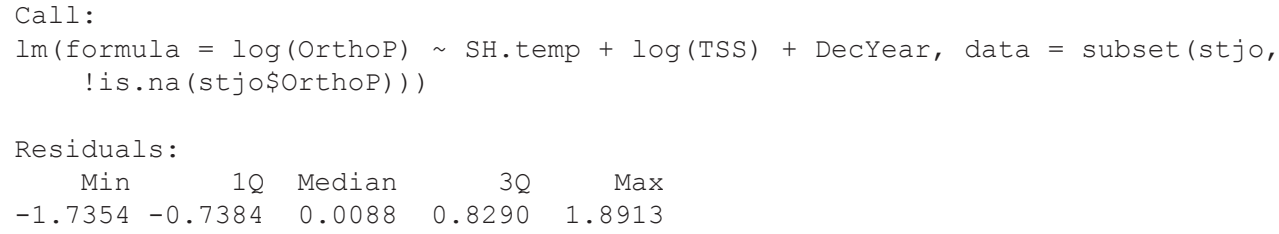




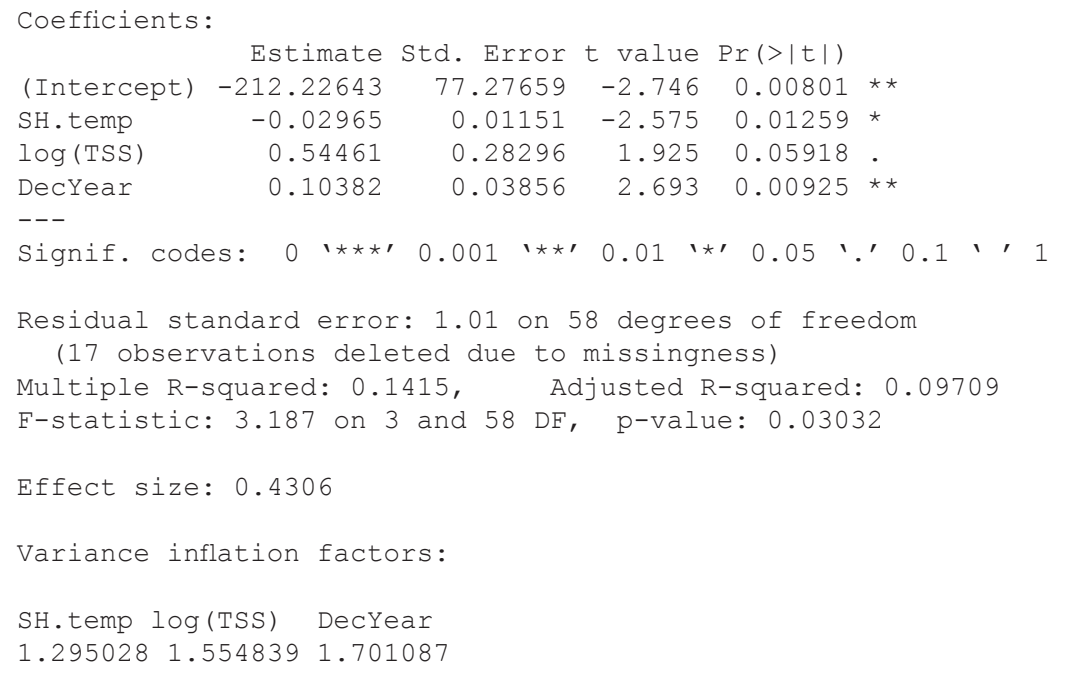

\section{Indiana Harbor and Ship Canal}

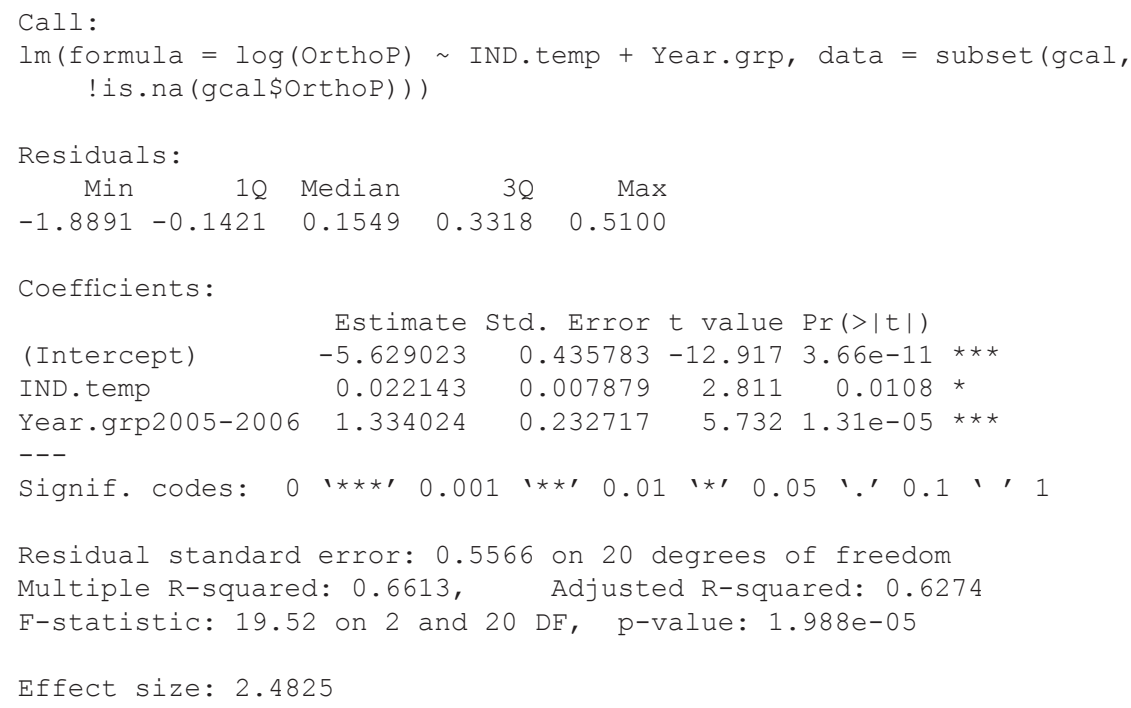

\section{Fox River}

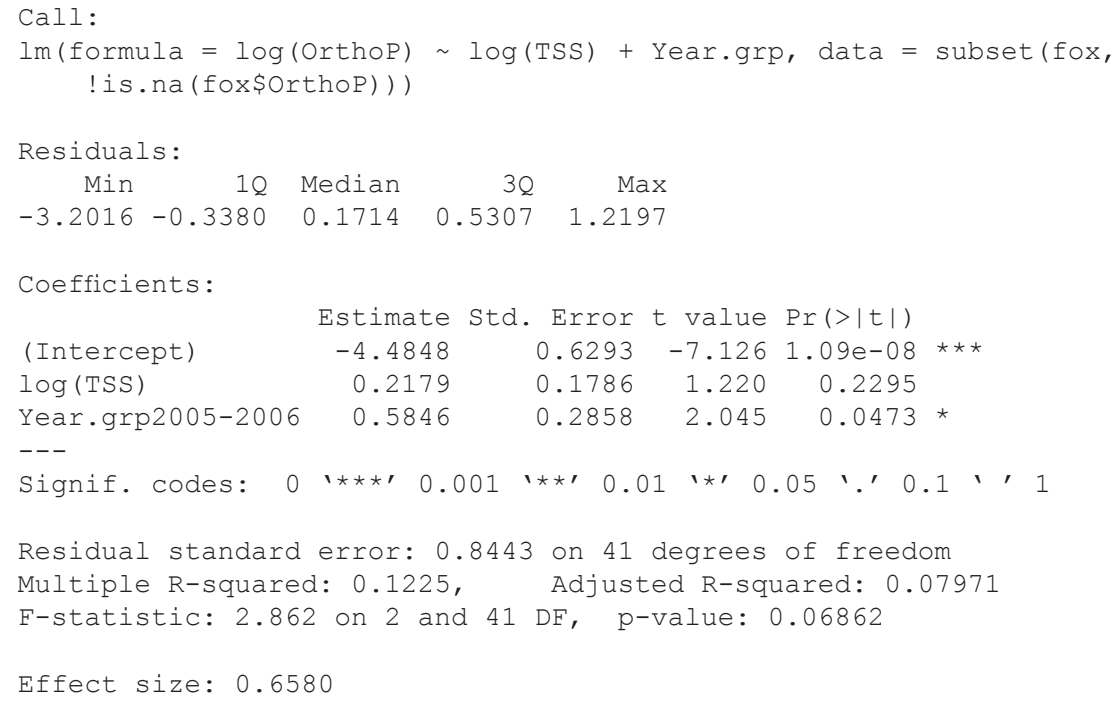




\section{Nitrate Plus Nitrite}

\section{Kalamazoo River}

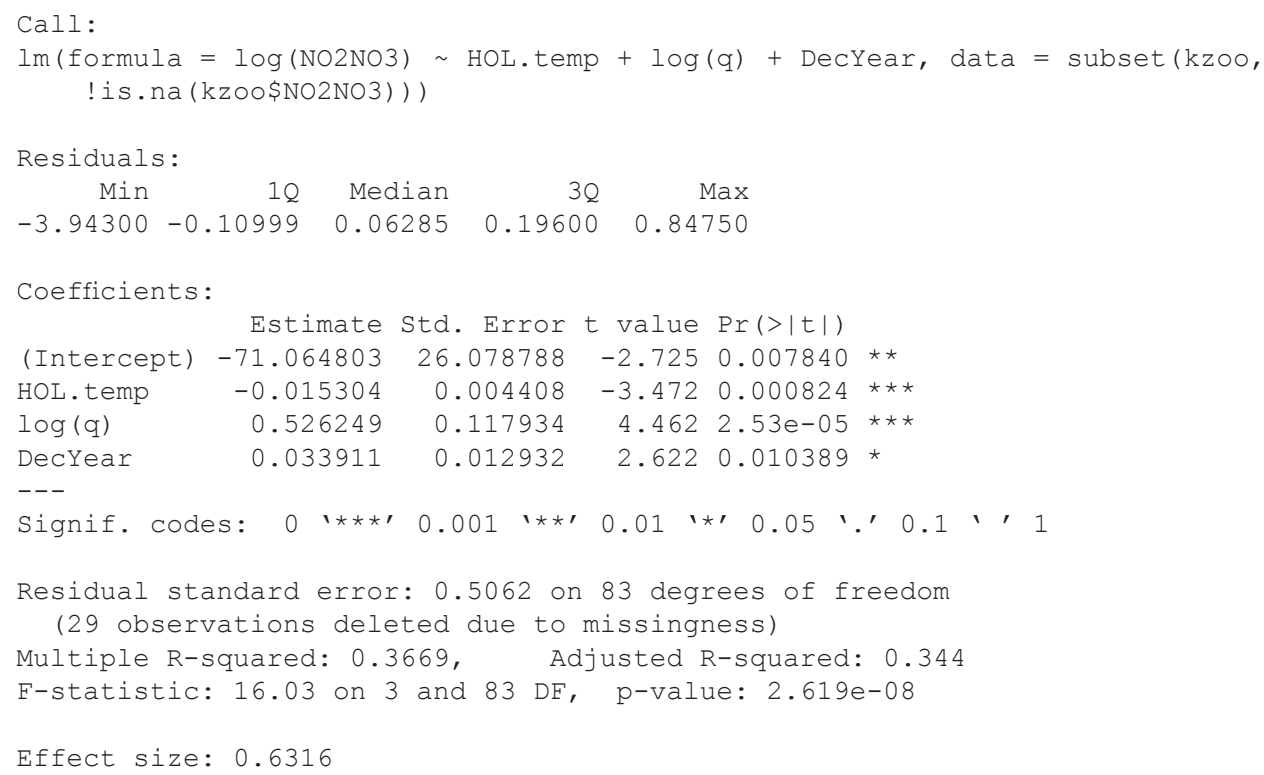




\section{St. Joseph River}

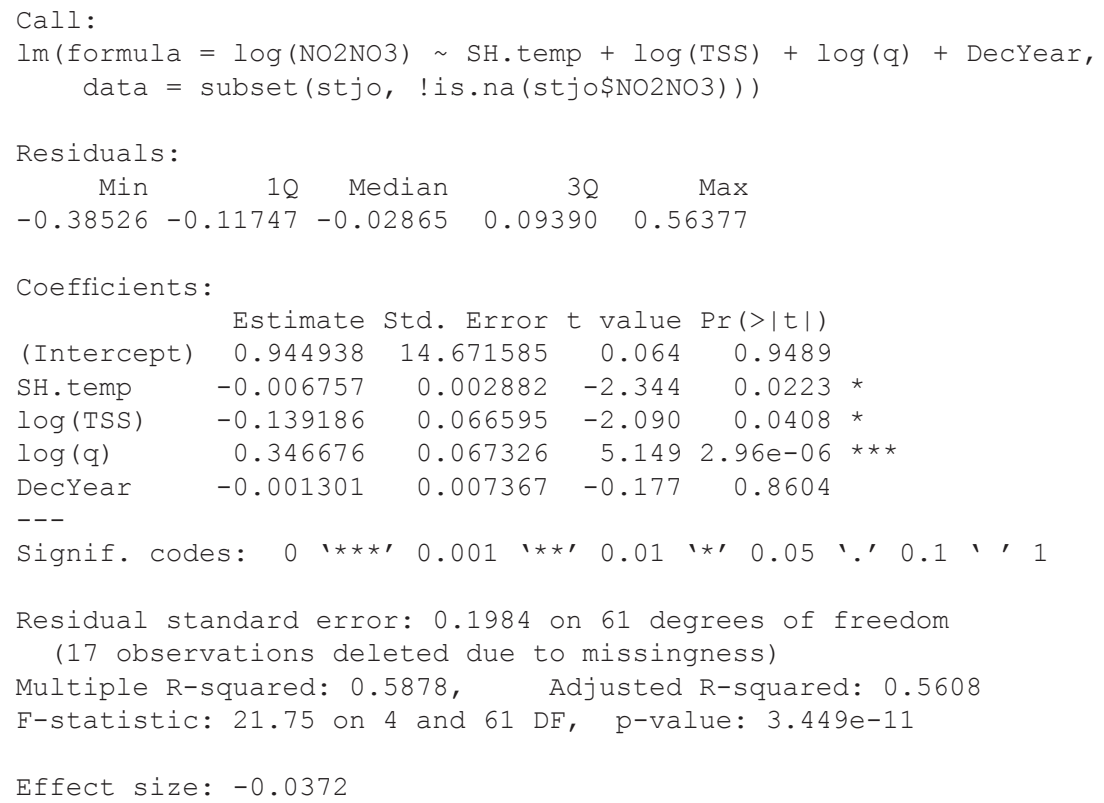

\section{Indiana Harbor and Ship Canal}

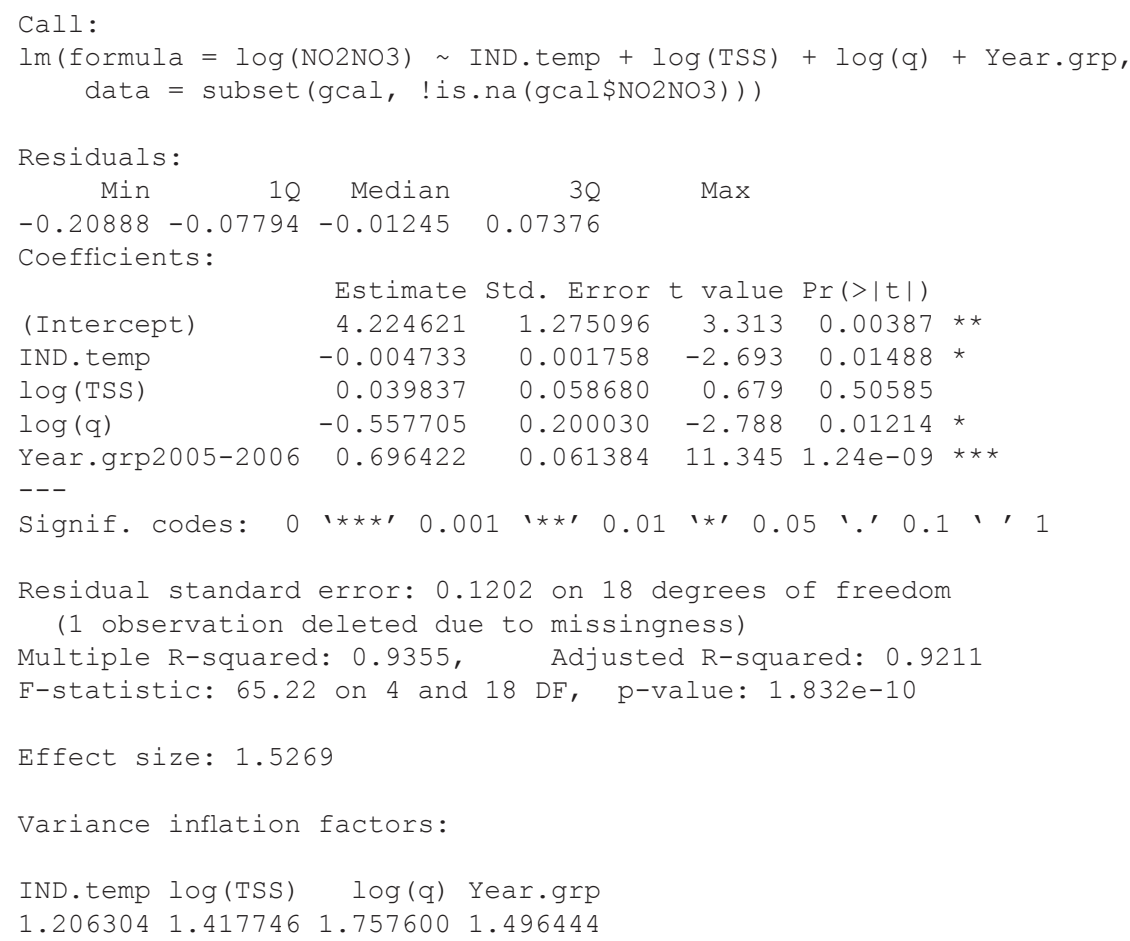




\section{Fox River}

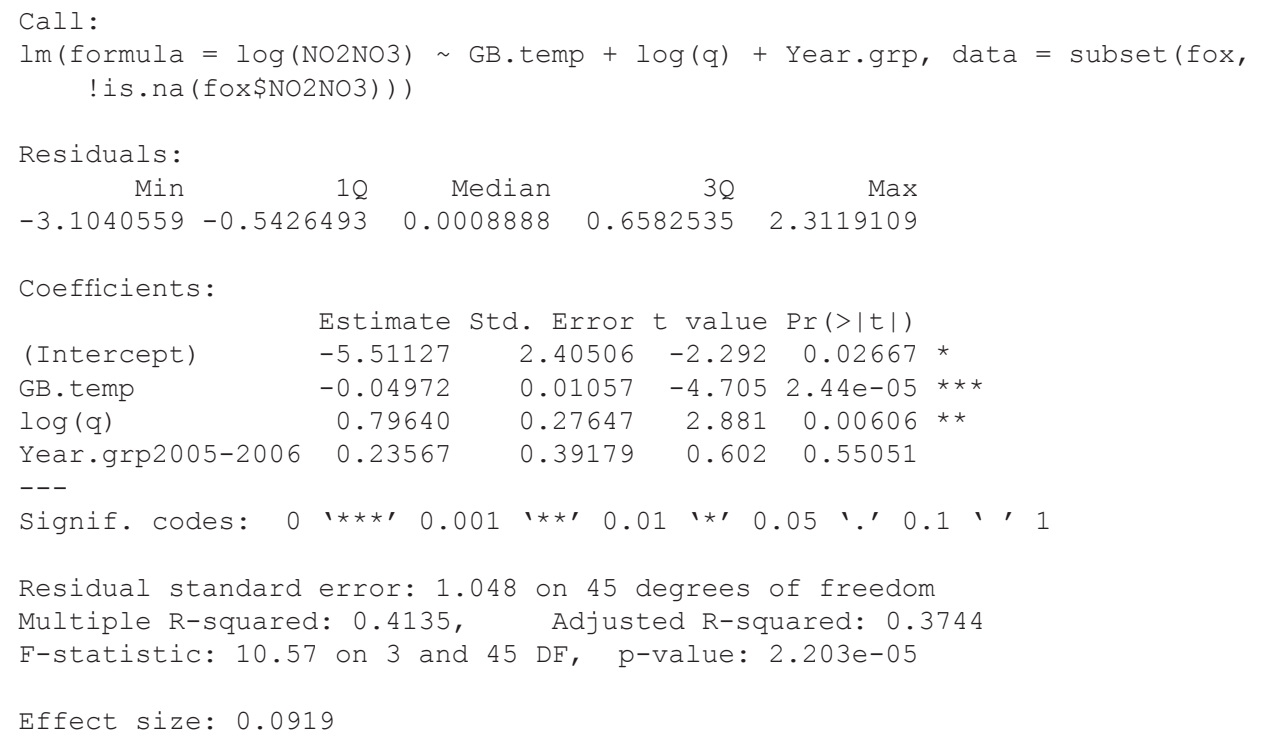


This page is intentionally blank. 
Publishing support provided by the U.S. Geological Survey Publishing Network, Columbus Publishing Service Center

For more information concerning the research in this report, contact the Director, Wisconsin Water Science Center

U.S. Geological Survey

8505 Research Way

Middleton, Wisconsin 53562

http://wi.water.usgs.gov/ 
